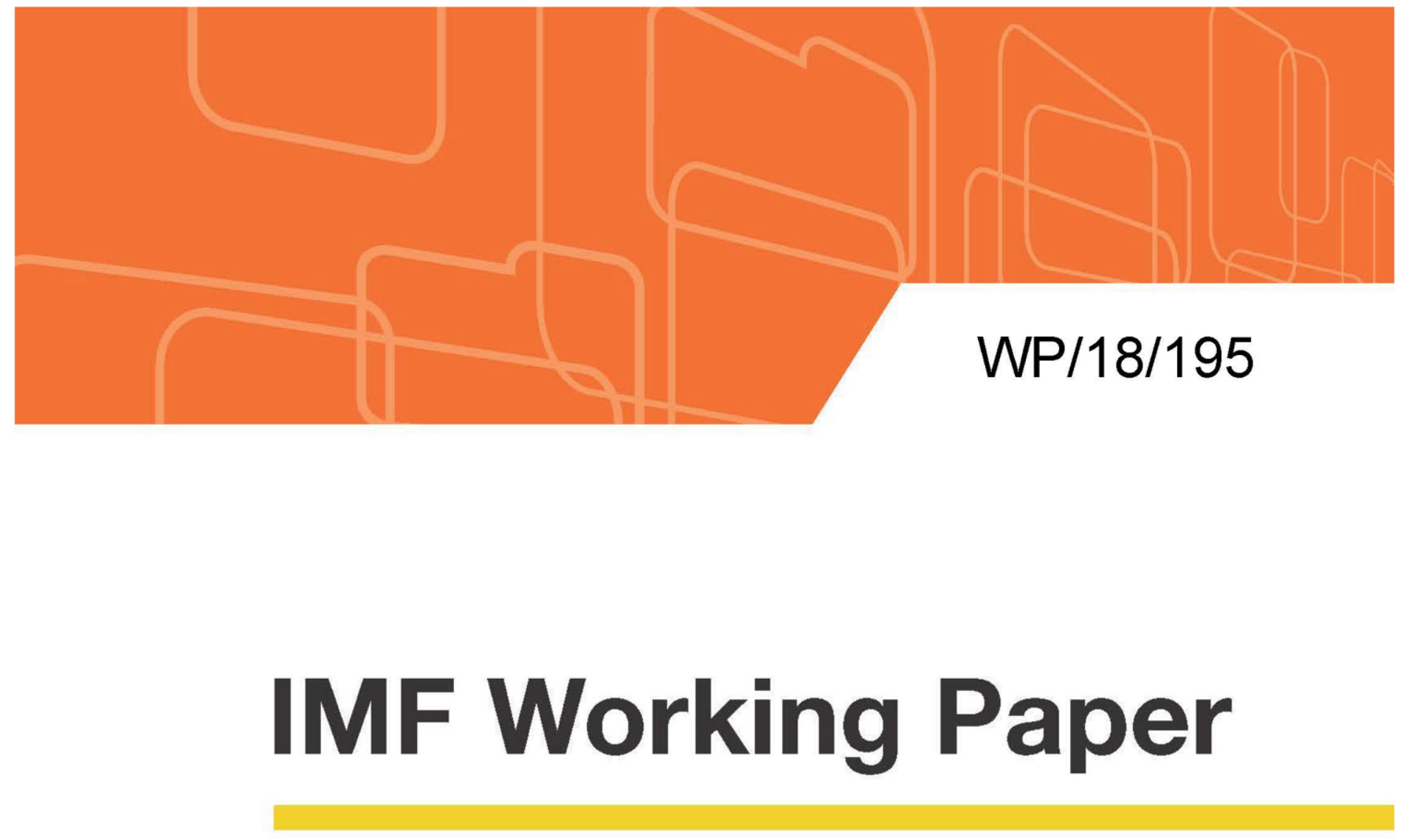

\title{
The Measurement and Macro-Relevance of Corruption: A Big Data Approach
}

Sandile Hlatshwayo, Anne Oeking, Manuk Ghazanchyan, David Corvino, Ananya Shukla and Lamin Leigh

IMF Working Papers describe research in progress by the author(s) and are published to elicit comments and to encourage debate. The views expressed in IMF Working Papers are those of the author(s) and do not necessarily represent the views of the IMF, its Executive Board, or IMF management.

I N T E R N A T I O N A L M O N E T A R Y F U N D 


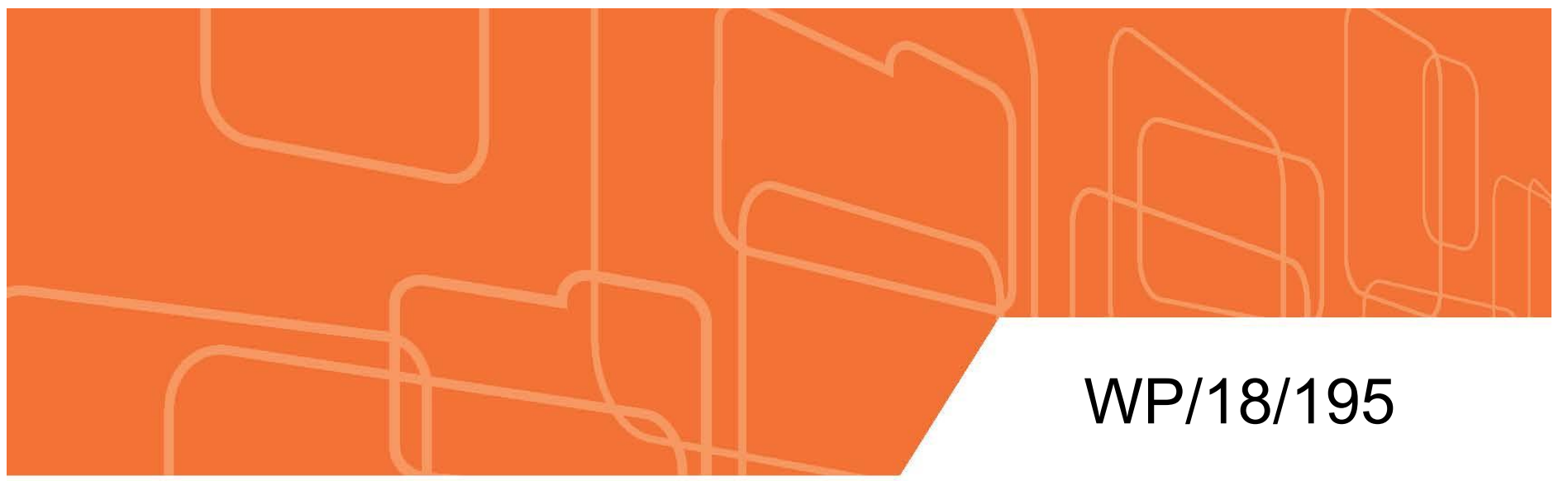

\section{IMF Working Paper}

\section{The Measurement and Macro-Relevance of Corruption: A Big Data Approach}

Sandile Hlatshwayo, Anne Oeking, Manuk Ghazanchyan, David Corvino, Ananya Shukla and Lamin Leigh

IMF Working Papers describe research in progress by the author(s) and are published to elicit comments and to encourage debate. The views expressed in IMF Working Papers are those of the author(s) and do not necessarily represent the views of the IMF, its Executive Board, or IMF management.

I N T E R N A T I O N A L M O N E T A R Y F U N D 


\title{
IMF Working Paper
}

Asia and Pacific Department

\section{The Measurement and Macro-Relevance of Corruption: A Big Data Approach ${ }^{1}$ \\ Prepared by Sandile Hlatshwayo, Anne Oeking, Manuk Ghazanchyan, David Corvino, Ananya Shukla and Lamin Leigh}

Authorized for distribution by Kenneth Kang

August 2018

IMF Working Papers describe research in progress by the author(s) and are published to elicit comments and to encourage debate. The views expressed in IMF Working Papers are those of the author(s) and do not necessarily represent the views of the IMF, its Executive Board, or IMF management.

\begin{abstract}
Corruption is macro-relevant for many countries, but is often hidden, making measurement of it - and its effects - inherently difficult. Existing indicators suffer from several weaknesses, including a lack of time variation due to the sticky nature of perception-based measures, reliance on a limited pool of experts, and an inability to distinguish between corruption and institutional capacity gaps. This paper attempts to address these limitations by leveraging news media coverage of corruption. We contribute to the literature by constructing the first big data, cross-country news flow indices of corruption (NIC) and anti-corruption (anti-NIC) by running country-specific search algorithms over more than 665 million international news articles. These indices correlate well with existing measures of corruption but offer additional richness in their time-series variation. Drawing on theory from the corporate finance and behavioral economics literature, we also test to what extent news about corruption and anti-corruption efforts affects economic agents' assessments of corruption and, in turn, economic outcomes. We find that NIC shocks appear to negatively impact both financial (e.g., stock market returns and yield spreads) and real variables (e.g., growth), albeit with some country heterogeneity. On average, NIC shocks lower real per capita GDP growth by 3 percentage points over a two-year period, illustrating persistence in the effect of such shocks. Conversely, there is suggestive evidence that anti-NIC efforts appear to have a sustained positive macro impact only when paired with meaningful institutional strengthening, proxied by capacity development efforts.
\end{abstract}

JEL Classification Numbers: D73

Keywords: corruption, anti-corruption, capacity development, big data, text analysis

Author's E-Mail Address: SHlatshwayo@imf.org; AOeking@imf.org; MGhazanchyan@imf.org; DCorvino@,imf.org; AShukla@,imf.org; LLeigh@imf.org

\footnotetext{
${ }^{1}$ The authors would like to thank Koshy Mathai profusely for motivating this research project and providing invaluable guidance and input throughout. We would also like to thank Changyong Rhee, Markus Rodlauer and Kenneth Kang as well as participants at several IMF seminars and country teams within the IMF's Asia and Pacific Department for their valuable comments. The project has also benefited from discussions with Robert Klitgaard during his course on "Fighting Corruption" at the IMF. Finally, the authors would like to thank Francis Landicho for outstanding editorial work.
} 
Table of Contents

I. INTRODUCTION__

II. CONNECTIONS AND CONTRIBUTIONS TO THE LITERATURE __ $\underline{\mathbf{5}}$

A. The Impact of Corruption __

B. Measuring Corruption __ 1

III. MEASUREMENT - CONSTRUCTION OF THE NEWS FLOW INDICATOR OF CORRUPTION AND ITS ROBUSTNESS _ 9

A. Construction of the NIC __ 9

B. The NIC's Advantages and Limitations ___ 11

C. Robustness of the NIC _

D. Stylized Facts _

IV. THE MACRO-RELEVANCE OF CORRUPTION-THEORETICAL FRAMEWORK AND EMPIRICAL RESULTS _

A. Theoretical Framework

B. Empirical Approaches and Results __ 22

V. ANTI-CORRUPTION EFFORTS-SELECTED COUNTRY CASE STUDIES, USE OF TECHNOLOGY AND THE ROLE OF CAPACITY DEVELOPMENT _—_ $\underline{32}$

A. Anti-Corruption in the Context of Belief Formation

B. Effectiveness of Anti-Corruption Efforts ___ _

C. Anti-Corruption Interventions ___

VI. CONCLUSIONS ___ $\underline{42}$

BOXES

1. Refinements and Extensions to the Baseline NIC Measure ___

2. Singapore: The Development of a Holistic Anti-Corruption Strategy ___

3. The Role of Digitalization in Combatting Corruption __ 44

4. IMF's Capacity Development work and Anti-Corruption Drive ___

\section{FIGURES}

1. Three Generations of Corruption-Related Measurement

2. Illustrative Country Examples of the NIC __ 15

3. Correlation with Other Corruption Indices __ 17

4. NIC and Anti-NIC Sample Averages ___ 17

5. NIC Comparison Across Income Groups __

6. NIC in Commodity Exporters and Anti-NIC Developments ___

7. NIC, Beliefs, and Macro-Outcomes ___ 21

8. Institutional Correlations _ 23

9. Abnormal Stock Market Returns and Stock Market Volatility Event Studies____ 24

10. Two \& Five-Year Bond Yield Spread Event Studies ___ 25

11. Exchange Rate Event Study ___ 25 
12. Capital Flow Event Studies__

13. Fiscal Event Studies _ 26

14. Growth Event Study

15: Anti-NIC Event Study _ 2

16. Anti-NIC Event Studies

17. Longer-Run Changes in the NIC by Anti-NIC Quintile___

18. Anti-NIC and NIC in Indonesia __ 36

19. Anti-NIC and NIC in Malaysia

20. Technical Assistance Field Time Estimates and Change in NIC ___

\section{TABLES}

1. NIC Search Algorithm Results Audit

2. Comparisons of the NIC Measures with its Refinements \& Extensions __ 16

3. NIC Full Sample Results

4. NIC Sub-Sample Panels Results, by Income Classification and NIC Level

5. Anti-NIC Full Sample Results

6. Capacity Development x Anti-NIC Nexus Full Sample Results

$\underline{41}$

\section{APPENDICES}

I. Search Algorithm Dictionaries

II. Construction of the News Flow Measure of Corruption __

III. NIC Robustness Checks

IV. Stylized Facts: NIC and Anti-NIC

V. Additional Panels Estimations Results

VI. Data Description and Sources 


\section{INTRODUCTION}

Corruption - defined as "the abuse of public office for private gain"-is macro-relevant for many countries, but is often hidden, making measurement of it and its effects inherently difficult. ${ }^{1}$ Prior literature has made several attempts to improve the indicators measuring corruption, but many still fall prey to numerous critiques. ${ }^{2}$ Large scale, surveybased perception indicators tend to be sticky and many claim they do not reflect actual corruption. ${ }^{3}$ Expert-based measures rely only on a limited pool of perspectives. ${ }^{4}$ Indicatorbased measures sometimes use regulatory sophistication and efficiency to identify vulnerabilities to corruption, but cannot reject the argument that such outcomes may reflect institutional capacity gaps. ${ }^{5}$

\section{To address such critiques, this paper explores how news media can help improve and} inform our understanding of corruption and its effects. Specifically, the paper focuses on three research objectives. First, we construct big data, cross-country news flow indices of corruption (NIC) and anti-corruption (anti-NIC) - the first of their kind - by running countryspecific search algorithms over more than 665 million international news articles. The measures offer several methodological improvements to existing measures, including the use of a more transparent and reproducible approach. Second, we explore how corruption-related news might engender changes in macro-outcomes from a theoretical perspective, and whether there is empirical evidence to support this lens. Finally, we highlight how institutional strengthening through the use of technology and capacity development can strengthen standard anti-corruption strategies.

The NIC measures news flow about corruption; it does not directly measure corruption. However, insights from the corporate finance and behavioral economics literature suggest that all relevant news - in our case, corruption-related news - shapes beliefs and behaviors in a persistent manner, allowing us to relate the NIC and anti-NIC to economic outcomes. The first relevant strand of the literature has its origins in the efficient market hypothesis from Fama (1970): asset prices will respond immediately and with the correct magnitude to newly public and relevant information. We would thus expect financial variables to respond to news about corruption scandals, as measured by the NIC. The second strand of the literature features macro models that capture the lingering effects of large and negative shocks. In Kozlowski et al. (2017), for instance, outcomes are affected by agents' beliefs, and those

\footnotetext{
${ }^{1}$ The literature has used several definitions of corruption. The classic definition of corruption is "the misuse of public power for private gain." Similarly, Jeremy Pope, the former head of Transparency International, has defined corruption as "the misuse of entrusted power for private benefit" (Pope 2000:2). IMF (2016) uses the definition "the abuse of public office for private gain" and this paper follows that basic definition of corruption. More on definitions and causes of corruption can be found in Amundsen (2000), Michael and Polner (2008), Anderson and Gray (2007) and Ferreira, Engelschalk, and Mayville (2007).

${ }^{2}$ For more comprehensive survey of other corruption-related third party indicators and their weaknesses, see the digest of the IMF's (2017) Use of Third Party Indicators.

${ }^{3}$ For example, see the Transparency International's Corruption Perception Index.

${ }^{4}$ For example, see the International Country Risk Guide's corruption measure.

${ }^{5}$ For example, see the European Research Centre for Anti-Corruption and State-Building's Index of Public Integrity.
} 
beliefs can be persistently scarred. In our context, large shocks to the NIC impact economic agents' assessments of the nature and extent of underlying corruption and these revised assessments change beliefs and sentiment in a persistent manner that filters through to financial variables and longer-term real macro-outcomes.

Our empirical results show evidence of the macro-relevance of corruption-related news and anti-corruption efforts, but only when the latter is paired with institutional strengthening. In particular, we find evidence of corruption-related news' negative impact on borrowing costs, exchange rates, market outcomes, capital flows, fiscal balances, and growth. The effects are persistent: NIC shocks lower real GDP per capita growth by roughly 3 percentage points, cumulatively, over a two-year period. On their own, anti-NIC shocks do not produce statistically significant impacts on growth. However, when coupled with capacity development efforts, real GDP per capita growth significantly and cumulatively increases over a three-year period. While the latter results are sensitive to model specification, they suggest that capacity development can reinforce anti-corruption efforts.

The rest of the paper is organized as follows. Section II surveys the literature on the macro-relevance of corruption and summarizes our measures' contributions to the literature. Section III describes the construction of the news flow indicator and its strength relative to existing indicators. Section IV provides the basic theoretical framework for assessing the macro-relevance of corruption news as well as some empirical findings on the link between the NIC and financial and real macro variables. Section V focuses on anti-corruption efforts, using our complementary anti-NIC indicator as well as country case studies and a review of the use of technology and capacity development. Section VI concludes.

\section{CONNECTIONS AND CONTRIBUTIONS TO THE Literature}

\section{A. The Impact of Corruption 6}

\section{Prior literature has highlighted several channels through which corruption can have a macroeconomic impact. Specifically:}

- Public finances. Revenue collection — in particular tax revenues — can be lower, for example through corruption's impact on tax compliance and tax evasion (e.g., Aghion et al., 2016). At the same time, corruption can weaken the quality of public expenditure and public investment projects through distorted procurement processes, off-budget financing, misallocated budgets, and cost inflation. Taken together, corruption can increase fiscal deficits and lead to substantial debt accumulation. Overall, lower government revenues and wasteful public spending due to corruption can harm investment, distort economic activity, and could lead to debt crises (e.g., Tanzi and Davoodi, 2002; Kaufmann, 2010; Achury et al., 2015).

\footnotetext{
${ }^{6}$ This section of the paper partly draws on IMF (2016).
} 
- Monetary and financial stability. Inflation can be higher in an environment of corruption as weaker public finances foster fiscal dominance, thereby eroding the central bank's operations and monetary policy (e.g., Huang and Wei, 2006; Cavoli and Wilsom, 2015). Corruption can lead to weaker financial market policies and oversight which negatively affects financial development and inclusion, lending practices and banking supervision (Detragiache et al., 2005). Regulatory weaknesses can undermine the stability of the financial system. Also, perception of corruption can increase borrowing costs via a higher default risk (e.g., Akitoby and Stratmann, 2010).

\section{- Growth.}

- Corruption can have a negative effect on growth through different channels. It can change incentives for individual actors to pursue rents instead of productive work, and could stimulate emigration of the highly educated workforce to less corrupt countries that value productive activity over rent-seeking (Murphy, et al., 1991). It can therefore have a negative impact on human capital through brain drain and inequality as skilled personnel emigrate abroad; furthermore, distorted public spending can undermine social services, education and health spending (Gupta et al., 2002; Rajkumar and Swaroop, 2008). Lower productivity among firms can also hurt innovation. Corruption can harm competitiveness - for example through hindering entry of new firms and forcing market exits due to the additional cost of corruption (Campos, et al., 2010). Similarly, besides the impact on public investment, corruption has been shown to reduce private investment, including FDI.

- However, some literature has argued for a "greasing the wheel" hypothesis, i.e. that corruption can have a positive impact on growth by compensating for bad governance. Corruption is viewed as a second-best solution to economic and structural problems that arise either due to overregulation or a weak institutional environment (Lee, 1964; Huntington, 1968; similar arguments in Lee and Oh, 2007; Marquette and Peiffer, 2015). Most empirical literature does not give strong support to this hypothesis (see Méon and Sekkat, 2005 for an overview). But some literature has shown a non-linear relationship between corruption and growth, attributing it to the quality of political or economic institutions (Mauro, 1995; Acemoglu et al., 2003; Heckelman and Powel, 2008). For example, Heckelman and Powell (2010) show that corruption can be growth enhancing when economic freedom is limited, but the positive effect vanishes with higher degrees of economic freedom.

- Trust. Corruption is likely to weaken citizens' trust in institutions and processes. An expanding strand of the literature shows that low trust amongst households can lead to lower financial inclusion (e.g., the use of informal credit) and lower stock investment (Guiso, Sapienza, and Zingales, 2004; Sapienza \& Zingales, 2012). Trust is also important in the cross-country context; perceptions of low trustworthiness across countries is associated with lower trade, direct investment, and portfolio investment 
(Guiso, Sapienza, \& Zingales, 2009). In extreme cases, corruption can undermine trust in the government, inciting civil unrest and conflict; more uncertainty can harm investment and other economic activity.

\section{B. Measuring Corruption}

Prior analytical work on corruption has been stymied by measurement isuses. Given that corrupt actors go to great lengths to keep their activities hidden, corruption is intrinsically secret and therefore difficult to capture. Therefore, it is not surprising that there have been several attempts in the literature to improve the indicators measuring corruption.

- The first generation measures of corruption - and most widely known - relied on surveys that measure expert and citizens' perceptions of the prevalence and nature of corruption (see Figure 1). ${ }^{7}$

- To move from perceptions to more objective measures of corruption, a second generation of measures tried to directly measure corruption with victimization surveys ${ }^{8}$ and bureaucratic quality indicators (e.g., tax collection efficiency or fiscal transparency). ${ }^{9}$ While such measures offer insight on the nature and extent of corruption across countries, especially when used in tandem, they also fall prey to several critiques: like the first generation, they too rely on perceptions, which are subjective and sticky; some private providers of governance indicators are not transparent about their methodologies; and indicator-based measures may reflect differences amongst countries in bureaucratic capacity, not corruption.

- Over the past decade, increasing access to large databases and the exponential spread of internet usership have ushered in a third generation of measures of corruption unified by their use of big data. Examples of such measures include India's IPaidABribe.com and procurement analyses that identify contractual outliers and politically-motivated shifts in the awarding of government contracts. Third generation measures adopt a less subjective, transparent, and reproducible methodological approach; they do not rely on a select group of experts to assess the level and nature of corruption; and they provide a higher frequency, less sticky indicator.

\footnotetext{
${ }^{7}$ Prominent examples of the $1^{\text {st }}$ generation of measures include Transparency International's Corruption Perceptions Index (CPI) and the World Bank's Control of Corruption measures.

${ }^{8}$ Rather than asking suvey participants about their perceptions of corruption, victimization surveys asked if participants experienced corruption directly.

${ }^{9}$ Prominent examples of the $2^{\text {nd }}$ generation of measures include Transparency International's Global Corruption Barometer and the Mungiu-Pippidi's Index of Public Integrity.
} 
Figure 1. Three Generations of Corruption-Related Measurement

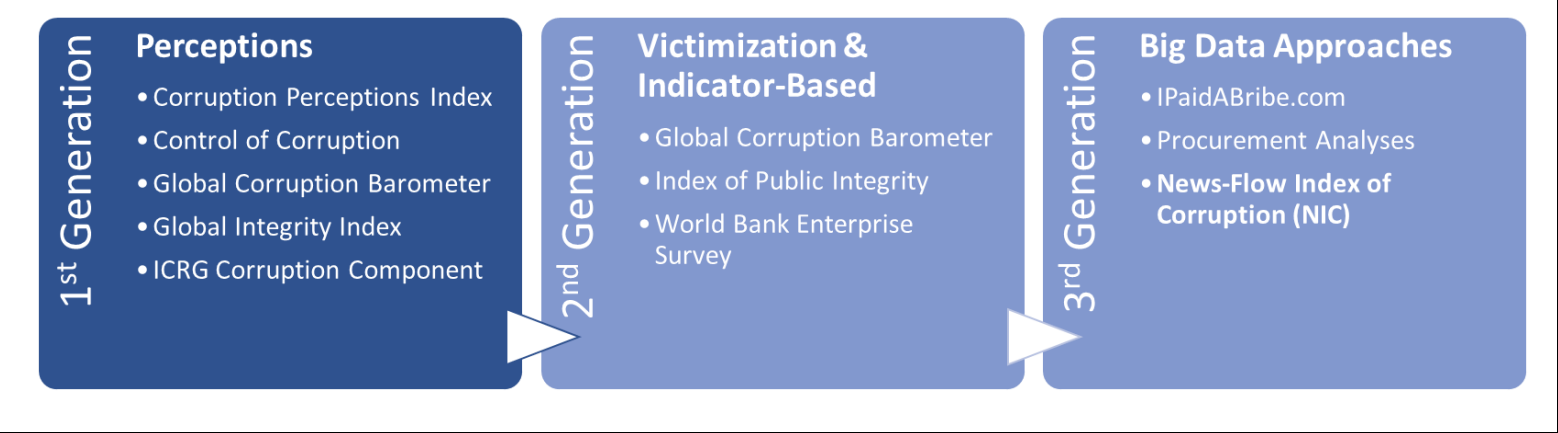

The NIC and anti-NIC measures contribute to the third generation of corruptionrelated indices that leverage big data approaches. They are the first big data, crosscountry news flow indices of corruption (NIC) and anti-corruption (anti-NIC) and improve on current big data approaches by not relying on governments to share procurement data or the unvetted reports of citizens. Also, the approach allows us to construct measures of anticorruption news flow (anti-NIC), which provides insight into the magnitude and persistence of anti-corruption efforts across time.

Using news coverage to measure otherwise "difficult to capture" has been widely used in recent years. Brogaard and Detzel (2012), Hlatshwayo and Saxegaard (2016), Baker et al. (2016) and others use news coverage to capture policy uncertainty in major economies; Grigorian and Manole (2017) adopt a similar approach to measure sovereign risk; and Shapiro (2017) uses news to pick up shifts in market sentiment. ${ }^{10}$

\section{Prior literature has also used news media and online search results in the study of} corruption. For example, Costas-Pérez, et al. (2012) explore how Spanish land use scandals affected the vote shares of incumbents, using the magnitude of domestic newspaper coverage as a measure of the extent and quality of information transfer on the scandals. Other countryspecific examples include: Rizzica and Tonello (2018) for Italy, and Zhu and Lu (2013) and Griffen et al. (2017) for China. Finally, Goel, et al. (2012) use the number of search engine results based on a search for corruption, bribery, and a country's name to proxy for corruption awareness. However, the approach suffers from several methodological failings (e.g., the measure cannot distinguish between anti-corruption and corruption or assess the number of false positives). Compared to this literature, in addition to using news coverage in a cross-country context, our algorithms are far more nuanced than prior approaches (e.g., our algorithms ensure unidirectionality of the measure) and have been properly vetted by human audits.

\footnotetext{
${ }^{10}$ Further literature making use of news-chatter includes Gunnemann (2014), Redl (2015) and Arbatli et al. (2017).
} 


\section{Measurement-CONSTRUCTION OF The NeWS Flow IndiCator OF CORRUPTION AND ITS ROBUSTNESS}

\section{A. Construction of the NIC}

\section{The NIC is constructed by running country-specific search algorithms on a newspaper} database of more than 650 million articles dating back to the mid-1980s. By counting the number of articles that reference corruption relative to more generic mentions of a particular country in the news media, the measure picks up the intensity of news coverage of corruption over time and across countries. The algorithms were designed based on the use of broad dictionaries of corruption-related terms, the feedback of journalists and professors of journalism, expert opinions from IMF country teams, and refinements based on preliminary human audits (see below for more detail). Our sample covers 30 countries from 1995 to 2017. ${ }^{11}$

Country-specific search algorithms are used to count the number of articles that meet a five-part metric. This comprises:

- Mention of the country within 8 words of a corruption mention. In our baseline algorithm there are 18 corruption-related terms (see Appendix 1). The locational restraint of eight words is based on industry standards based on feedback from journalists and professors of journalism. ${ }^{12}$

- Mention of government. The NIC is meant to capture articles related to the abuse of public office for private gain; to ensure we are picking up public incidents and not private criminality, we include 22 government-related terms.

- No mention of an anti-corruption effort to ensure the measure is unidirectional (i.e., the intention is to pick up incidents of corruption, not the response to them).

- A length of at least 99 words so that "ticker" articles are not included and human audits can be conducted.

\footnotetext{
11 The sample of economies comprise Argentina, Australia, Bangladesh, Brazil, Cambodia, China, Colombia, Egypt, Germany, Hong Kong SAR, India, Indonesia, Italy, Japan, Korea, Lebanon, Malaysia, Mexico, New Zealand, Philippines, Russia, Singapore, South Africa, Spain, Sri Lanka, Thailand, Turkey, United Kingdom, United States, and Vietnam. The sample was selected to include mostly Asian economies, since they have been relatively understudied in the area of corruption and are very socioeconomically diverse. The remaining economies were selected to be broadly representative of other regions and income levels. All countries had to have a minimum level of journalistic coverage of them (i.e., 100 country-related articles per month, on average). For more detail on this requirement, see Box 1.

${ }^{12}$ We thank Sam Fleming (US Economics Editor at the Financial Times); Juliana Goldman (CBS News Correspondent, formerly at Bloomberg News); Douglas Foster (Northwestern University, Medill School of Journalism); and Kenichi Serino (University of Witswatersrand School of Journalism) for their time and contributions.
} 
- Limited to major newspapers with reputable credentials. ${ }^{13}$ In light of recent concerns around the veracity of news, we limit the source pool to major newspapers, which tend to have robust editoral processes in place to ensure articles are vetted and timely. ${ }^{14}$ This restriction also helps mitigate compositional biases that may enter by allowing the full universe of potential sources.

The anti-corruption algorithm is similar, except that it allows for the mention of both anticorruption and corruption. The algorithms are in English; see Appendix 1 for the full search algorithm dictionary sets. ${ }^{15}$

To account for differences in coverage in the database of articles across countries and over the sample period, the count of articles that meet the country-specific algorithm are divided by a normalizer. The normalizer is the count of all articles that reference the country, are from major news sources, and are longer than 99 words. If a country is temporarily the focus of international coverage (e.g., hosting the Olympics), news related to the country spikes, driving down the NIC. To address this, we smooth the normalizers using moving averages; thus, temporary "world interest" spikes have less bearing on the NIC's levels from year to year. ${ }^{16}$ Given that journalists also tend to cover more populated countries (e.g., China and the U.S.), the normalizer can also be thought of as controlling for differences in population size. Finally, the raw measures are indexed from $[0,100]$ across countries and time, with higher levels implying more news flow on corruption or anti-corruption, respectively.

To implement the search algorithms, we use Dow Jones's Factiva news aggregator, which covers over 36,000 sources. These sources include almost 700 newswires (e.g., the Associated Press and Reuters) and all major news sources (e.g. The Wall Street Journal; Financial Times; China Daily; Korea Times; The Australian; and All Africa). In addition to digitized newspaper inclusion dating back to the 1980s, newspapers' online websites (e.g., The Guardian Online, The New York Times Online) are also included. The news aggregator allows for filtering of results by language, source location, geographic coverage, company/industry, and a select group of subjects.

\footnotetext{
${ }^{13}$ Wires (e.g., Reuters and the Associated Press) often write articles that are re-published in their entirety in many leading newspapers. We do not remove these duplicate articles from the counts since their proliferation, in part, reflects the importance of the particular story.

${ }^{14}$ Factiva's top major news and business sources includes over 700 publications and is broad in its geographic coverage (e.g, includes the New York Times, the South African Press Association, the Nikkei, the Scotsman, Bangkok Post, Kyodo News, the Hindustan Times, and more).

${ }^{15}$ We only use English-language articles since publication in English is broad across regions and because we exclude owncountry sources due to concerns about domestic bias. See below for more detail and robustness checks.

${ }^{16}$ Arguably, moving averages still allow for the influence of outliers across periods despite helping mute them; however, we did not want to completely remove statistically-identifiable outliers that could reflect the addition of new sources, not just spikes in "world interest" because there are some compositional shifts in the database's coverage overtime.
} 


\section{B. The NIC's Advantages and Limitations}

\section{There are several advantages of the NIC approach's to measuring corruption.}

- The NIC uses publicly available and "vetted" news articles from major news sources, improving on other big data approaches that rely on unsubstantiated voluntary selfreporting by citizens (e.g., India's IPaidABribe.com) or the mining of governmentprovided procurement databases for irregularities (e.g., Transparency International's public procurement analysis). The latter case may suffer from reverse causality since less corrupt governments are also likely to be the ones willing to share such data. Finally, the broad coverage of papers helps address the concern that a particular paper, or papers from a specific region, could be biased.

- $\quad$ The NIC reflects higher frequency changes in measured corruption than existing measures that rely on sticky public perceptions and/or expert opinion. If a government's anti-corruption efforts lead to less corruption and fewer news stories about corruption, our measure reflects this and we can establish the macro-relevance of such efforts.

- Second generational indicator-based measures may reflect capacity gaps, not actual corruption. While indicator-based measures improve on perception-based measures by being more objective, they suffer from an identification problem since it is not immediately clear that poor government performance (e.g., low tax collection efficiency or revenue leakages) is driven by corruption or simply reflects low capacity within the government agency.

- News stories are timely. The press is often at the frontline of exposing corruption and are incentivized to release stories as soon as they are properly vetted to remain competitive (Costas-Pérez, et al., 2012).

- $\quad$ The NIC measures corruption in a salient manner by using stories from the daily newspapers. Economic actors rely heavily on news to inform their choices (Wolfers and Zitzewitz, 2016). A spike in newspaper coverage on corruption is likely to influence their beliefs and their resulting actions. In contrast, readership of the World Bank and Transparency International's annual reports on corruption, which are less frequent, may have less influence on real-time economic decision-making.

- The NIC reflects a broader pool of assessments than alternative measures. Most corruption indices are based on surveys or expert assessments, relying on a limited number of representatives. The NIC, by drawing on so many sources, does not suffer 
from an overreliance on a small pool of local experts or sources, which may be corrupted themselves. ${ }^{17}$

- The accuracy of the NIC can be assessed with a human audit of the measure. Our audit examines whether the articles that are counted reflect actual or perceived corruption; the country in question; increases or decreases in corruption; grand or petty corruption; and political purges. The audits also aided the team in revising the algorithm and refining the measures (see Box 1).

That said, the NIC also has some limitations, which we try to address. To the extent that countries have different degrees of press freedom or repression, the NIC may not be comparable across countries. For example, in countries where citizens are unable to exercise freedom of speech or freedom to protest, the NIC might be less likely to pick up coverage of corruption. To address this, we remove own-country sources, and adjust our baseline measure using time-varying measures of civil liberties and press freedom (see Box 1 for more detail). The search algorithms may also pick up private criminal activity instead of public corruption due to words that can be associated with both types of activity. Also, the difference between legal and illegal corruption may unduly lower the measurement of corrupt activities in advanced markets (e.g., state capture or excessive lobbying). Finally, in countries where corruption or broader journalistic coverage is relatively low, a single corruption scandal may lead to spikes in the NIC that are not reflective of underlying corruption (i.e., the noise-to-signal ratio may be high in such cases). However, this may be a distinction without a difference. Our theoretical framing rests on the impact of shocks to coverage of corruption, which - reflective of underlying reality or not — can affect beliefs; Rizzica and Tonello's (2018) find supportive evidence of this channel in the Italian context. To address the above limitations, Box 1 summarizes the ways that the NIC was refined and extended.

\footnotetext{
${ }^{17}$ One concern may be that journalists tend to be biased towards negative news, more generally, or certain countries, in particular. With respect to negative news, this is likely to be the case. However, in order for it to affect our ability to compare across countries and time, there would need to be systematically different negative bias towards certain countries. We did not see any evidence of this from the human audits. Moreover, the use of such a large pool of sources helps mitigate concerns about bias against a particular country.
} 


\section{Box 1. Refinements and Extensions to the Baseline NIC Measure}

\section{Refinements to the baseline index}

Press coverage of corruption is reliant on press freedom, the degree of repression of the domestic regime, and demand for coverage of the subject. In repressed societies, citizens are unlikely to feel free to express themselves to domestic or foreign press. To address this, we (1) remove "own country" sources from each country's search algorithm and (2) use Freedom House's Civil Liberties and Press Freedom index data to upweight the baseline measure for years when countries are characterized by low press freedom and/or high repression. These adjustments are applied after the baseline index is constructed. We refer to them as the Civil Liberties Adjusted NIC and the Press Freedom Adjusted NIC. Also, if a country's norm is the absence of corrupt incidents, then rare instances of corruption are likely to be heavily covered by local media. Rizzica and Tonello (2018) found evidence of over-reporting of corruption by domestic sources. Removing local sources from each countries' algorithm should also help moderate this issue.

The search algorithm dictionaries should be context-specific. As discussed in UNDP (2015), "proxy indicators tend to be very context-specific, because different contexts have varying traditions, social structures, and societal values." Special care was taken to refine the search algorithms by adding words based on country experts and removing words that have different cultural meanings in some countries (e.g., "patronage"), based on the human audit. Moreover, one benefit of using a big data approach that relies on international coverage is that journalists will tend to use (similar) language in describing instances of corruption and are not sensitive to local language norms.

The search algorithms may pick up private criminal activity, not corruption ("abuse of public office for private gain"). To avoid this, we removed wobbler words that might reference ethically problematic, but not corrupt activities (e.g., tax haven, offshore financial center, illicit financial flows). Our human audit results (shown below) suggest that we are largely capturing public corruption and not solely private criminal activity.

There could be limited information in the news measure if the amount of general news about a country is small. To ensure that the big data approach provides a critical sample size for each country, and to limit the noise-to-signal ratio, we exclude countries with limited press coverage as defined by 100 generic articles per month, on average (i.e., a normalizer cutoff metric of 1200 articles per year).

\section{Extensions}

In addition to the baseline measure of corruption news flow, we offer two extensions meant to buttress and help establish the robustness of our main index.

The baseline dictionary may be too broad. We included 18 corruption-related terms. On the one hand, this ensures we pick up a large variety of corruption-related articles (e.g., an article may mention bribery activities by a local official, but not use the word "corruption"). On the other hand, we may be increasing the number of false positives (e.g., articles that mention bribery, but refer to interactions between two private individuals). To explore this tradeoff, we create an extension called the Core Corruption NIC and limit the corruption dictionary word set to: corrupt*, kleptoc*, graft, and nepotism.

The baseline measure may be biased against less developed markets in its construction since it does not include a set of terms that relate to the type of "legal" corruption more likely to be seen in advanced markets. To address this, we add terms that relate to lobbying and state-capture of government by private interests. This new index is called the Lobbying Adjusted NIC. 


\section{Robustness of the NIC}

\section{Given the novelty of the NIC approach, we employ a battery of robustness checks to gauge the accuracy and performance of the NIC as a measure of the flow of corruption- related news. These include: conducting a human audit of the articles counted by the search algorithms; checking that the spikes and relative levels in the NIC correspond with country experts' priors; comparing relative levels of the baseline measure to its refinements and extensions; and examining the correlations of the NIC with existing measures of corruption.}

We conducted human audits on a random sampling of both the corruption and anticorruption search results, finding that both measures are robust. After selecting four countries at random, hundred of articles were randomly sampled for human auditing; the number of selected articles ensures the results have a $95 \%$ confidence level. ${ }^{18} \mathrm{~A}$ full list of audit questions can be found in Appendix 3. The results of the human audit suggest that the NIC and anti-NIC are robust (see Table 1 and Appendix 3).

- For the NIC, 96 percent of articles are both about the correct country and 88 percent are about corruption. Of the articles that are about the correct country and about corruption, only 3 percent are about declines in corruption and the articles largely pick up coverage of actual corruption-not simply perceptions. Finally, domestic government tends to be the source of

Table 1. NIC Search Algorithm Results Audit $\begin{array}{ll}\text { Correct Country? } & 96.1\end{array}$ About Corruption? $\quad 87.6$ Of correct country \& about corruption... Decrease? 3.1 Actual (vs. Perceptions)? Domestic Government as Source? $\quad 95.5$ \begin{tabular}{l|l} 
Foreign Entity as Source? & 3.5
\end{tabular} Related to a Political Purge? 9.4 Note: In percent. Based on a random sampling of 490 articles; $95 \%$ confidence level with $+/-5$ confidence interval. corruption and corruption coverage is only alleged to be related to political purges in 9 percent of audited articles.

- For the anti-NIC (see Appendix 3), over 80 percent of articles are both about the correct country and about anti-corruption efforts. Of the articles that are both about the right country and anti-corruption efforts, 88 percent are about actual efforts, rather than perceptions of efforts, and only 3 percent of the audited anti-NIC articles made reference to political purges.

The NIC captures major turning points on corruption scandals in countries. To gauge the NIC's robustness through time, we assessed spikes and relative levels in the NIC for each

\footnotetext{
18 The final round of human audits includes four countries and 780 articles; however, throughout the development of the measure, several rounds of human audits were performed on a wide range of countries within the sample. Altogether, we conducted well over 1,500 article audits. Another approach to evaluate accuracy is to compare a computer-generated algorithm to one that relies on a human reading of articles, as done by Baker, et al. (2016) who found the computer and human-generated indices to be highly correlated and also found that the algorithms were not particularly sensitive to any one term.
} 
country in our sample. Figure 2 shows three illustrative examples of an advanced economy (AE), an emerging market (EM), and a low-income developing country (LIDC).

Across our sample of countries (LICs, EMs and AEs), the NIC and its extensions seem to be in line with priors. In Table 2, we show the 1995-2017 period averages for the baseline NIC and its extensions. For corruption-related measures, higher numbers imply a higher average NIC level over the full sample period (i.e., relatively more corruption-related news). To illustrate the impact of the various adjustments we show how ordering shift for three example countries; for example, the EM country's order moves up once civil liberties are adjusted for, suggesting that it has low civil liberties relative to the rest of the sample countries. The ordering remain largely the same as the extensions and refinements are implemented and are closely correlated with each other (see Appendix 3, Table 1); the antiNIC is also positively related with the NIC, though to a far lesser degree.

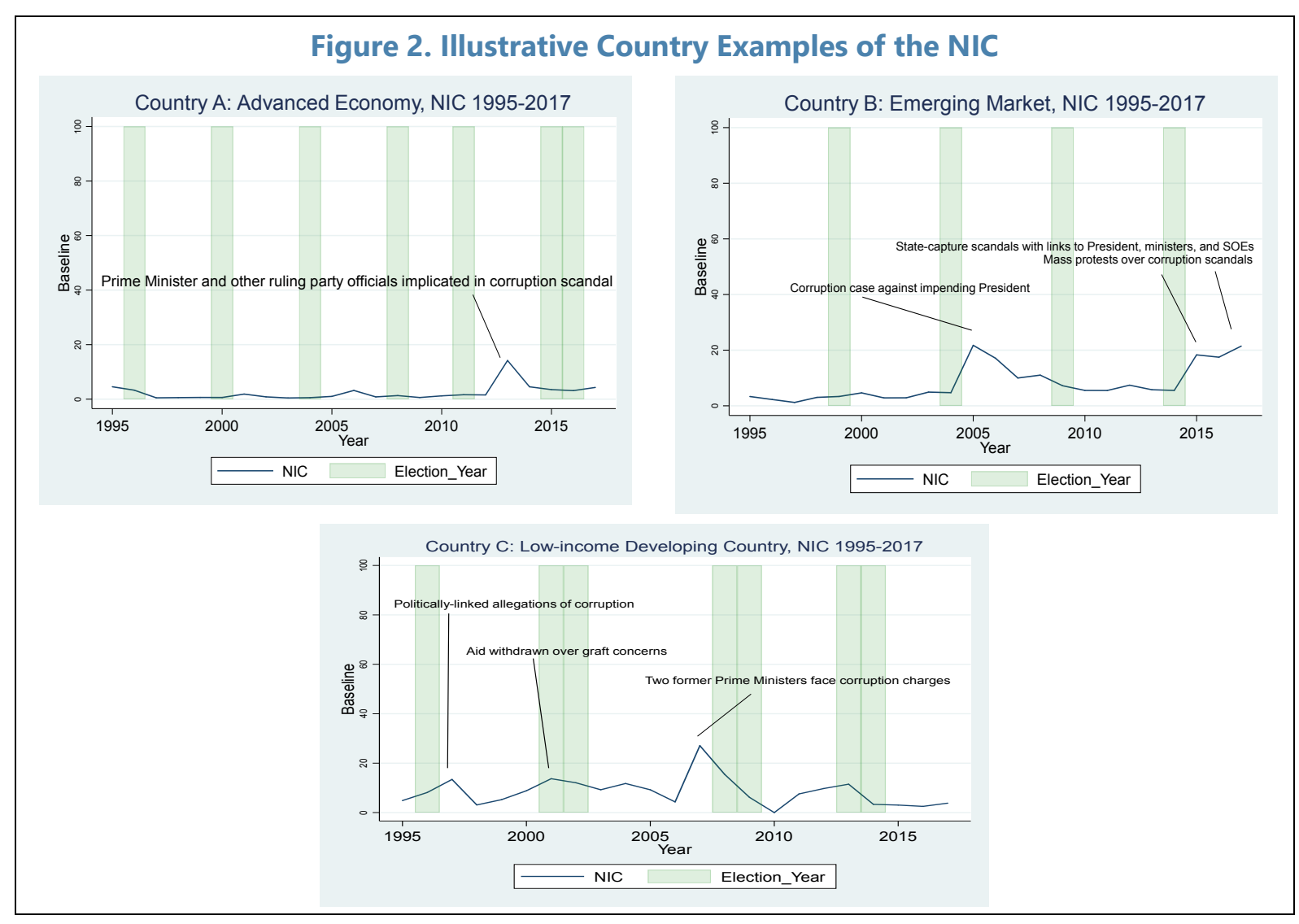




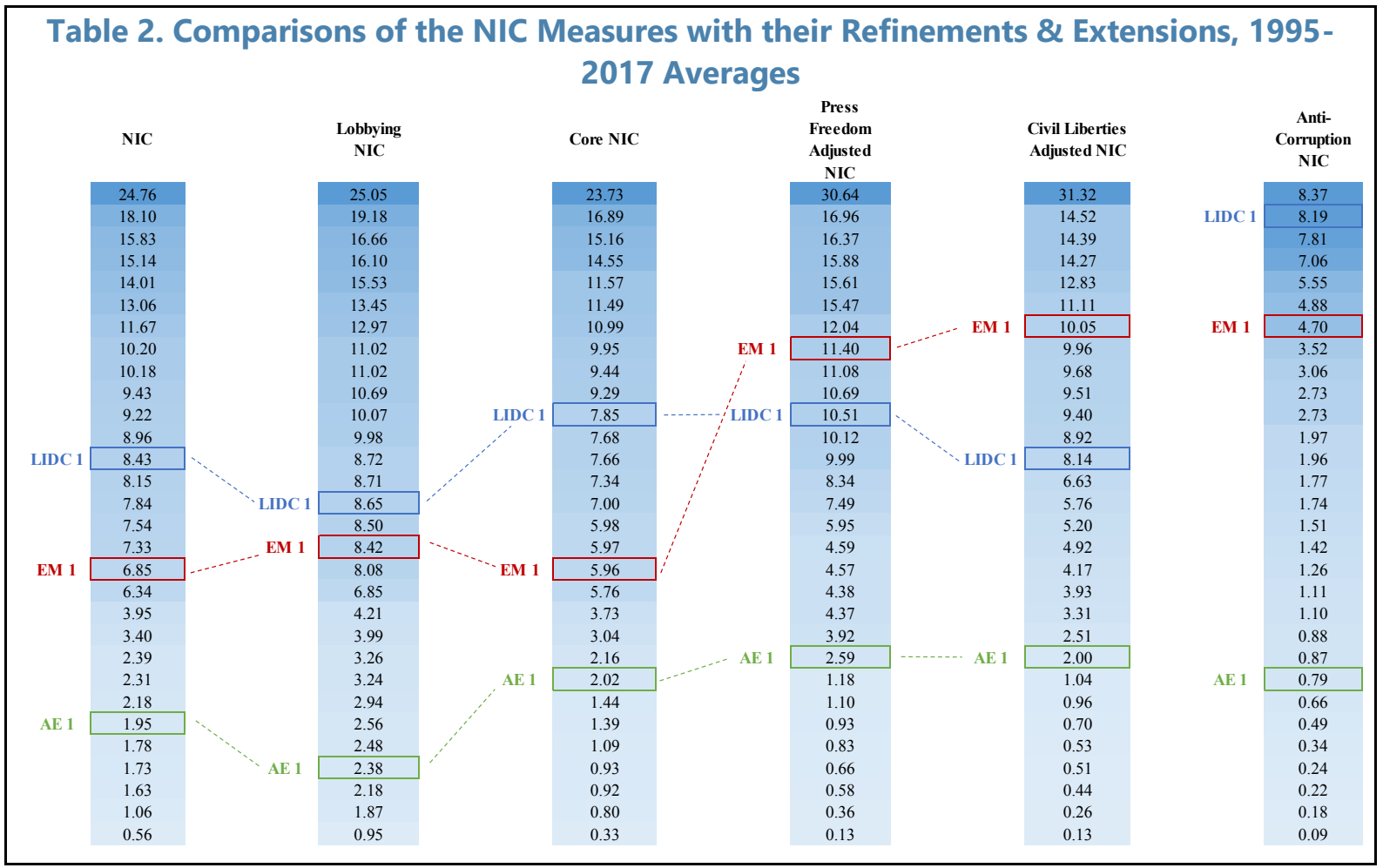

The NIC is also correlated with traditional indicators of corruption. As mentioned above, one concern we faced when constructing the measure was that journalists only tend to cover "new" news - major scandals. To the extent that a country faced long-standing systemic corruption we were unsure it would be fully reflected in the measure, suggesting that we could not make relative comparisons. But the NIC, when analyzed purely in level terms, appears to be highly correlated with traditional third-party indicators of corruption (see Figure 3). Comparing 5-year averages of the NIC and Transparency International's Corruption Perceptions Index (CPI) from 2012-16, we find a correlation of -0.69. ${ }^{19}$ A similar relationship is observed between the NIC and the WGI Control of Corruption (CoC) measure, also with a correlation of $-0.69 .{ }^{20}$ This tertiary finding buttresses such third-party indicators. ${ }^{21}$

\footnotetext{
${ }^{19}$ Corruption Perceptions Index scores range from 0 (country perceived as highly corrupt) to 100 (country perceived as very clean). Therefore, a higher score on the CPI signals lower perception of corruption. The 2012-16 average is constructed as a simple average of CPI scores across our 30 sample countries.

${ }^{20}$ Control of Corruption percentile ranks range from 0 (lowest rank) to 100 (highest rank). Therefore, a higher rank on the $\mathrm{CoC}$ signals lower perception of corruption. The 2012-16 average is constructed as a simple average of CoC ranks across our 30 sample countries.

${ }^{21}$ The NIC is also correlated with the World Bank's Bribery Incidence measure which measures the \% of firms experiencing at least one bribe payment request across 6 different standard public transactions. The correlation is .44 and is significant at the 10 percent level.
} 
Still, the NIC reflects far more variability across time relative to such measures. ${ }^{22}$
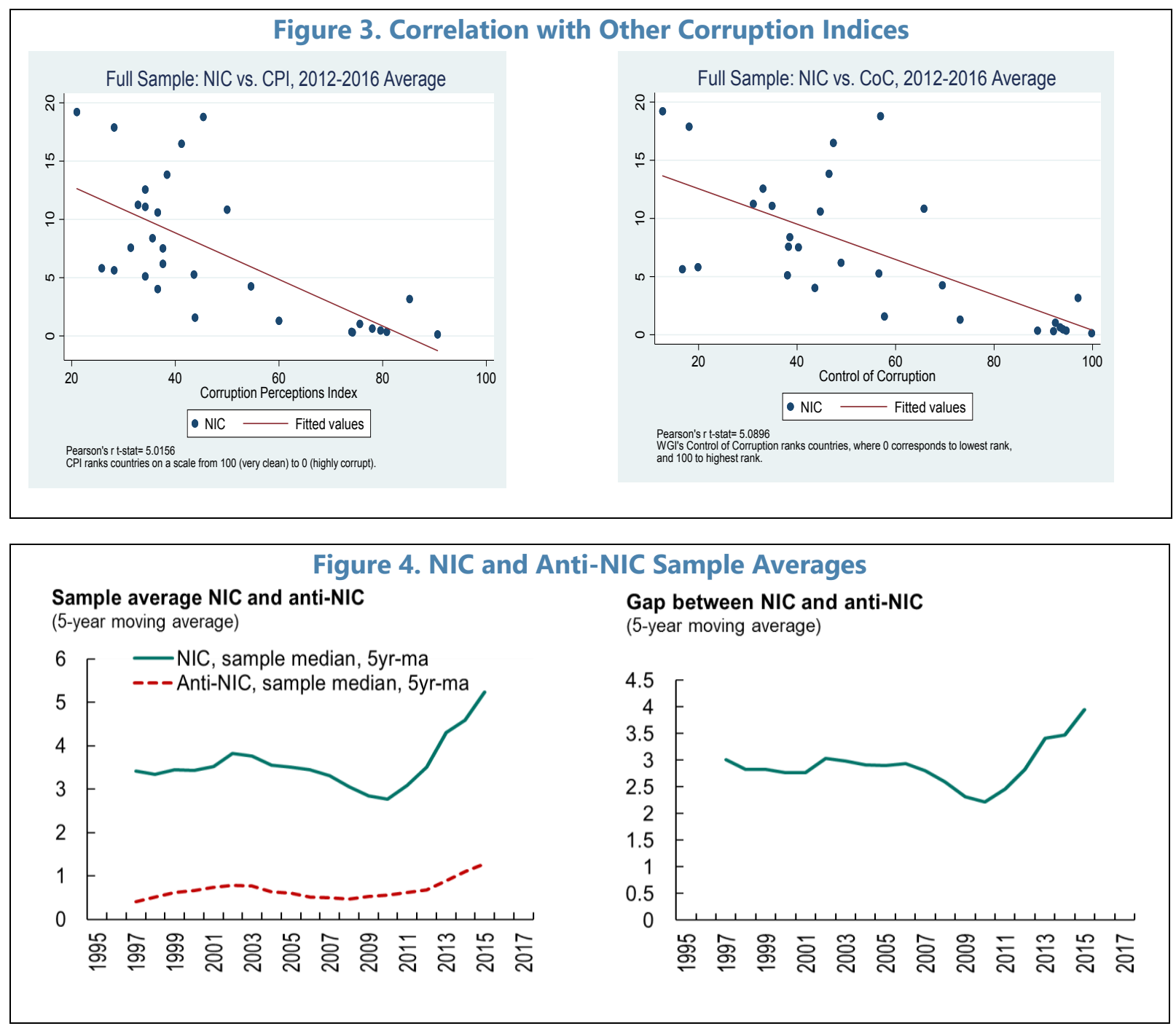

In summary, based on human audits, examination of the movements in the NIC across time and within countries, comparison of the NIC across its various extensions and refinements, and comparison of the NIC with other corruption-related measures, the measures are robust both with respect to relative levels as well as changes.

\footnotetext{
${ }^{22}$ In Appendix 3, Figure 4 shows that NIC captures more time variation relative to the CPI and CoC. While the average CPI and COC for the countries in our sample remains relatively consistent through 1995-2017, the NIC registers upward and downward shocks thus painting a more holistic picture. The NIC shows a marked increase in the later period (2012 onward) while the CPI remains constant and the COC falls. There is also heterogeneity across income groups in the behavior of the NIC relative to CPI and CoC over time (see Appendix 4). For AE's, the NIC rose in the last couple years, and while the CoC measure seemed to pick up a worsening in corruption perceptions, the CPI remained flat. In EM's, the CPI and the NIC diverge - while the CPI remained relatively flat over the past five years, the NIC rose during this period. For LIDC's, perceptions of corruption improved in the early 2000 s, but corruption-related news only dropped after 2010; the positive trends for LIDCs reversed in recent years for both CoC and the NIC.
} 


\section{Stylized Facts}

On average, the NIC has increased over the last decade (Figure 4). The anti-NIC has also trended upwards over recent years, suggesting an increase in anti-corruption efforts by countries in our sample. However, it has greatly lagged behind the corruption news flow, and the gap between the NIC and anti-NIC has widened.

On average, the NIC is higher in countries at lower levels of development, in line with a priori expectations. Figure 5 shows that the NIC is considerably lower in advanced economies (AEs) as compared to emerging markets (EMs) and low-income developing countries (LIDCs). ${ }^{23}$

Across income groups, the NIC displays heterogeneity in time variation, with LIDCs seeing large improvements in NIC levels in the recent period. AEs show a consistently low level of corruption-related news flow across our time-period, however, there has been a slight uptick in the AE's NIC starting in 2016. EMs have had a moderate amount of corruption-related news flow across the sample period, with two major spikes, from 19992002 and 2009-2015. LIDCs have shown a marked decrease in average NIC levels compared to the 1990s, hitting a 15 year low in 2016 - although there is a large degree of heterogeneity amongst LIDCs' performance. ${ }^{24}$

The NIC has been on an upward trend in EMs and commodity exporters (CEs) following the global financial crisis. Figure 5 shows an increase in the NIC for EMs (20092015), and the left panel in Figure 6 shows an increase for CEs (2009-2012). ${ }^{25}$ Interestingly, the increase in the NIC for EMs coincided with a period of large capital inflows into EMs.

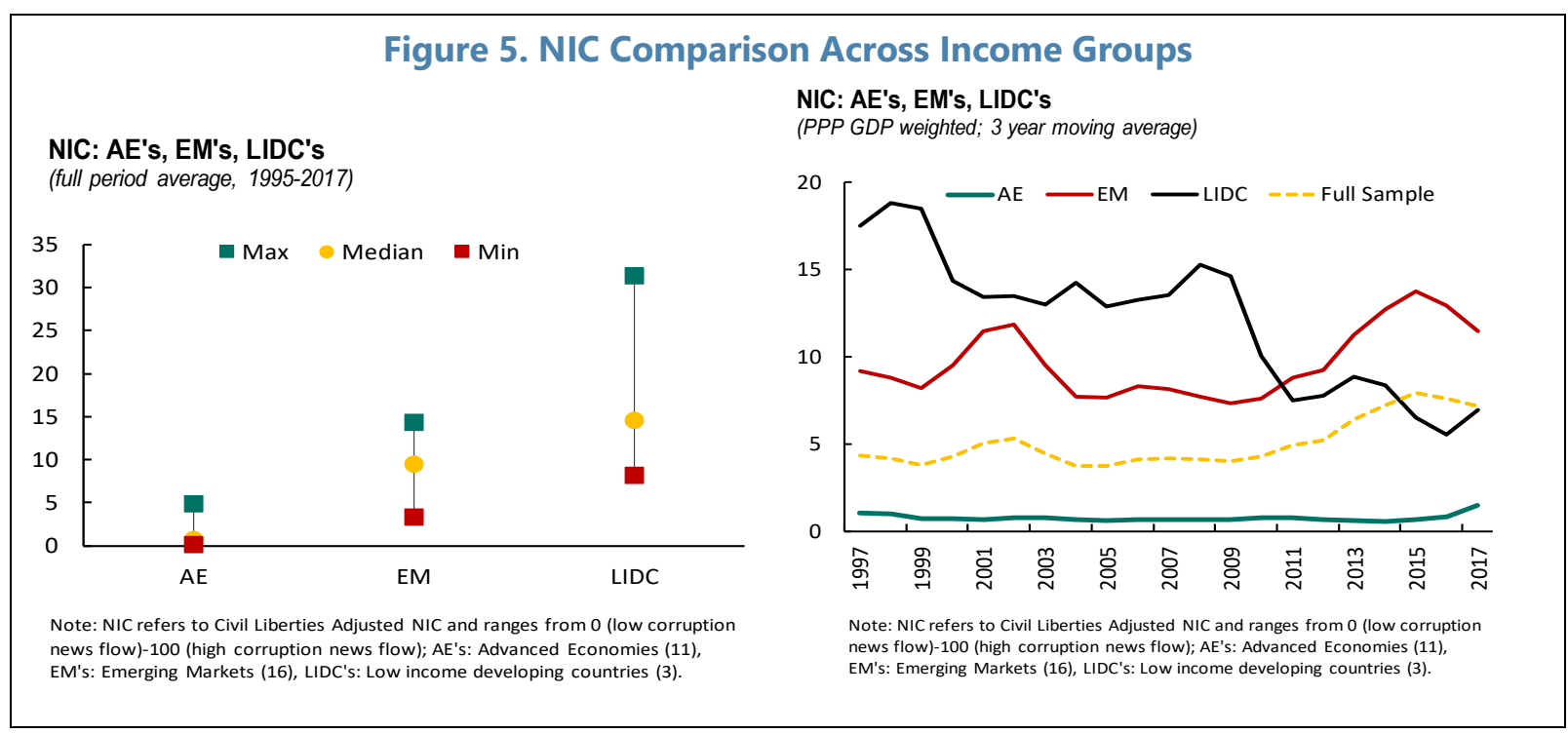

\footnotetext{
${ }^{23}$ Summary statistics for the NIC and Anti-NIC can be found in Appendix IV.

${ }^{24}$ The average of annual standard deviations over the sample period are 11.20 for LIDCs; 7.29 for EMs; and 1.79 for AEs.

${ }^{25}$ Commodity and non-commodity exporters have similar average annual standard deviations of 7.50 and 8.63 , respectively.
} 
Anti-NIC levels remain low across the sample period, irrespective of income levels. ${ }^{26}$ Figure 6 shows that anti-corruption related news flow has remained consistently low across time with the exception of a large uptick in the LIDC's between 2006-2008. The large uptick in LIDCs in 2006-2008 is driven primarily by one country's news flow on anti-corruption efforts that led to the arrest of thousands of officials across various political parties. News on anti-corruption efforts in EMs saw a slight increase between 2012 and 2016.

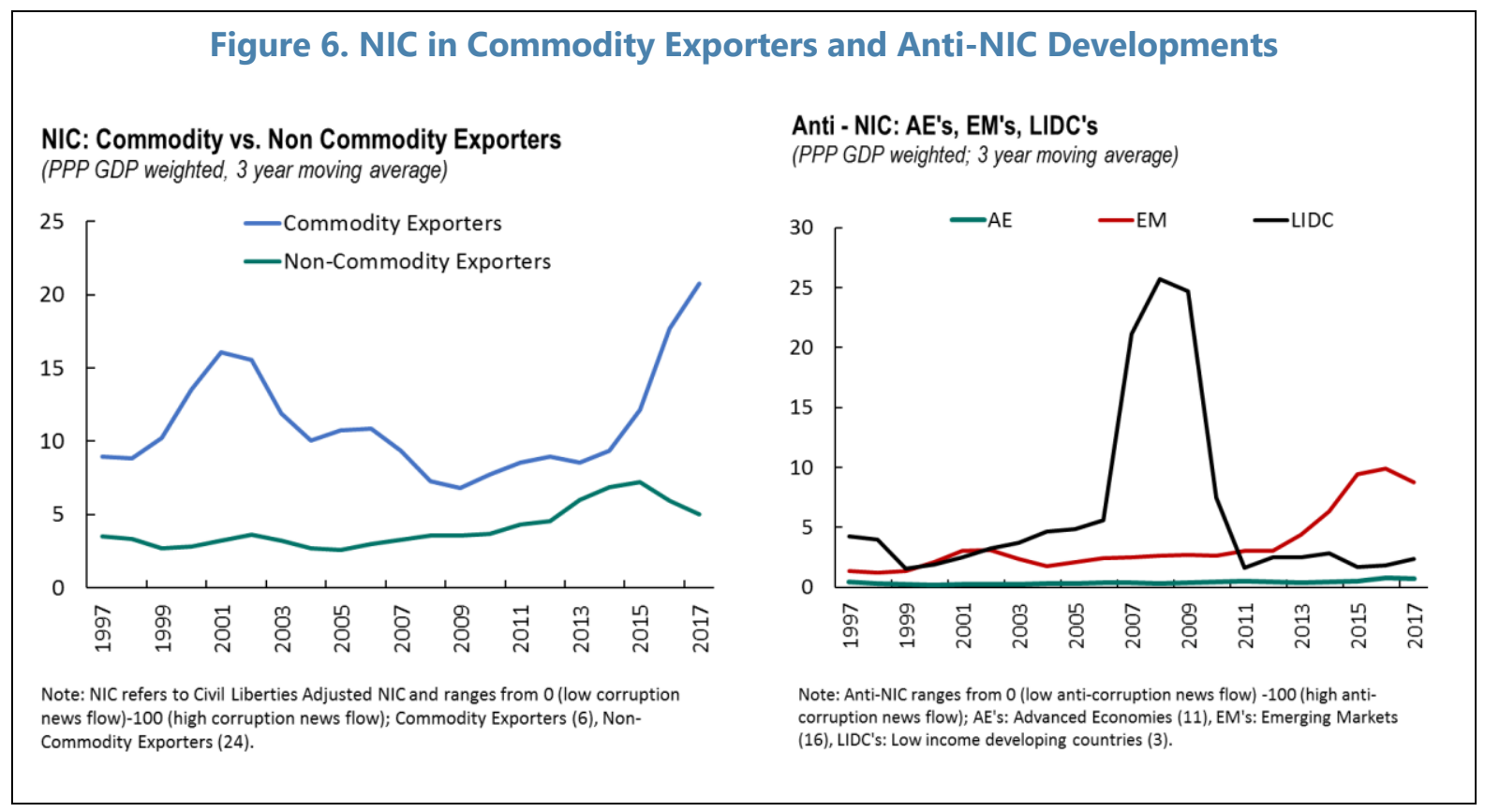

\section{The MaCro-ReleVANCE OF CORRUPTION-THEORETICAL FraMEWORK AND EMPIRICAL RESULTS}

\section{A. Theoretical Framework}

This section provides a theoretical framework for our news-based analytical approach. The framework underpins how our news-based measures of corruption and anti-corruption can drive changes in short-term fundamentals, shifts in longer-run beliefs, and eventually feed into macro-relevant outcomes. We draw on two strands of the theoretical literaturecorporate finance and macro-behavioral economics.

\footnotetext{
${ }^{26}$ There is also less variation across countries for the Anti-NIC, relative to the NIC - with an average annual standard deviation of 4.33 vs. 8.90 for the NIC.
} 


\section{The corporate finance literature has long relied on news shocks to conduct event} studies. The underlying theoretical foundation for this work is Fama's (1970) semi-strong efficient market hypothesis - a company's stock prices will respond to newly public and relevant information, with the appropriate magnitude. ${ }^{27}$ In using changes in news coverage to measure corruption, we are implicitly drawing on this theoretical foundation by assuming that economic actors will respond to newly available public coverage of corruption in the news media, just as they would respond to any newly relevant information. These expected price reponses to changes in the NIC can be summarized with the following expected return equation:

$$
E\left(\widetilde{p_{z, t+1}} \mid \theta_{t}, \Delta N I C_{t}\right)=\left[1+E\left(\widetilde{r_{z, t+1}} \mid \theta_{t}, \Delta N I C_{t}\right)\right] p_{z, t}
$$

Where $p_{z, t}$ is the price of a security $\mathrm{z}$ at time $\mathrm{t} ; \widetilde{r_{z, t+1}}$ us the one-period percentage return; $N I C_{t}$ is the news-based index of corruption; $\theta_{t}$ is all other publicly available information relevant to a stock's value; and tildes reflect random variables at time t. The conditional expectations imply that the information sets $\theta_{t}$ and $\Delta N I C_{t}$ are utilized in calculating expected returns and, thus, the information sets are also reflected in time $t$ for $p_{z, t} \cdot{ }^{28}$

The belief formation process assumes that large shocks have lasting effects. Empirical evidence from the behavioral economics literature shows that news media can have persistent impacts on everything from voting preferences to choices over family size (e.g., DellaVigna $\&$ Kaplan, 2007). We also find that the NIC Granger-causes the CPI and CoC (see Appendix 3 , Table 2), suggesting that changes in news flow about corruption shift perceptions about corruption. In any particular period, changes in the NIC will generate changes in prices; however large shifts in the NIC - for instance, due to a corruption scandal involving the leader of a country - are more likely than traditional news (e.g., a quarterly earnings report) to bias investors' opinions in a persistent manner. Alternatively stated, large corruption shocks are likely to change beliefs about the underlying prevalence of corruption in a country with large "level effects." This suggests that large shocks to the NIC may generate long-run changes to investor behavior. To formalize this belief formation process, let $\Delta N I C_{t}$ be i.i.d. corruption shocks for a country with a true, but unknown range of corruption (e.g., low, medium, high). Let $\sigma$ represent this true underlying density. ${ }^{29}$ Each agent has a history of all corruption shocks $\Delta N I C_{t}$ up to and including t. At each $\mathrm{t}$, agents construct a normal kernel density estimator of $\sigma$ :

\footnotetext{
${ }^{27}$ In semi-strong-form efficiency, it is implied that share prices adjust to publicly available new information very rapidly and in an unbiased fashion, such that no excess returns can be earned by trading on that information.

${ }^{28}$ While the NIC is a flow variable, changes in its rate of flow generate shifts in beliefs. Intuitively, if the same percentage of corruption-related articles each year does not change, then one's beliefs about the underlying nature of corruption would be unlikely to change.

${ }^{29}$ Corruption shocks in our setting can be considered i.i.d. given the hidden nature of corruption and the difficulty of uncovering corruption at any given moment.
} 


$$
\widehat{\sigma}_{t}(\Delta N I C)=\frac{1}{n_{t} \delta_{t}} \sum_{S=0}^{n_{t}-1} \Delta\left(\frac{\Delta N I C-\Delta N I C_{t-s}}{\delta_{t}}\right)
$$

Where $\Delta$ is the standard normal density function; $\delta$ is a smoothing parameter; and $n$ is the number of observations. Here, the larger and more rare the shock to the NIC, the more persistent the shock will be on beliefs. As agents commonly respond to the shift in beliefs en masse, there will be negative longer-term effects on real outcomes as illustrated below in Figure 7.

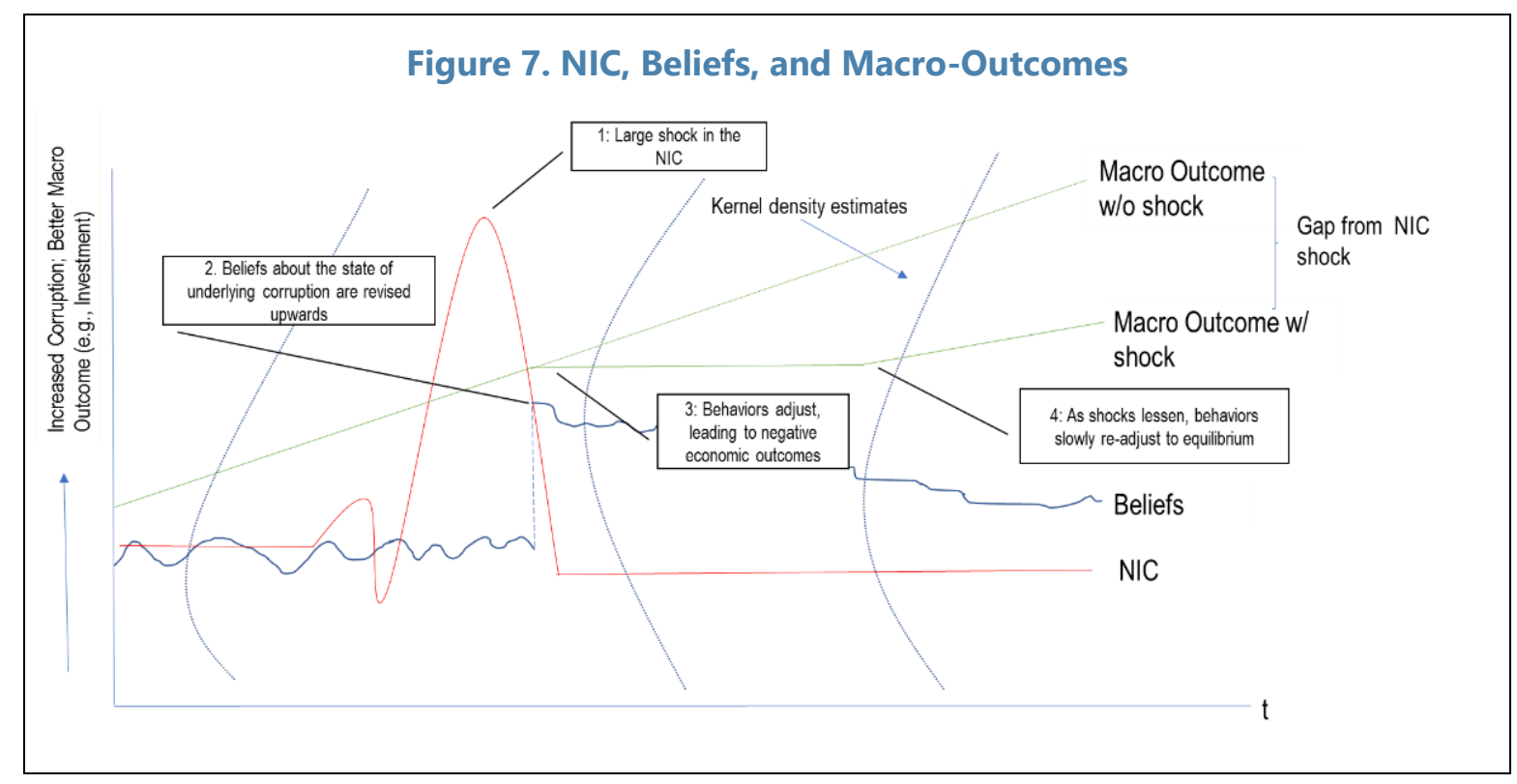

The connection between micro-models of belief formation like the one shown above and macroeconomic outcomes can be formalized by embedding this mechanism in a macromodel as in Kozlowski et al. (2017). Their paper explores how shocks like that of the Great Recession left scars in agents' behavior, irrespective of subsequent changes in macroeconomic fundamentals. In their paper, the authors model belief formation in a way that produces more persistent responses for more extreme shocks and based on the premise that "[n]o one knows the true distribution of shocks in the economy." This conceptualization is fitting for corruption, which — as mentioned before - is intrinsically difficult to assess due to its hidden or secretive nature.

\section{Together, these strands of literature can explain the link between our indirect} corruption measure and macro-relevant outcomes. Persistent belief formation and the semi-strong efficient market hypothesis suggest that there will be both short- and longer-term impacts of changes in measured corruption on outcomes. Figure 7 summarizes this process. 


\section{B. Empirical Approaches and Results}

Given the complex relationship between corruption and macro outcomes, the paper employs several analytical approaches to assess the macro relevance of corruption. These include correlations between the NIC and standard institutional variables (Stage 1) since corruption in many instances reflects broader institutional failures in the economy; event studies at different frequencies to assess the macro impact of shocks to the NIC (Stage 2); and panel estimations that control for a range of additional factors (Stage 3). While the first stage examines how the relative levels of the NIC line up with institutional and structural outcomes, the latter stages focus on how changes in beliefs about underlying corruption translate into changes in financial and macro outcomes. Throughout the remainder of the paper, we opt to use the civil-liberties adjusted measure as our preferred measure to address the concerns about outside media access in repressive regimes.

\section{Stage 1: NIC and Institutional Indicators}

We find the NIC to be significantly correlated with several measures of institutional quality. These measures include the World Economic Forum's Global Competitiveness Index; the World Governance Indicator's Regulatory Quality ranking; the World Bank's Ease of Doing Business Index; Linzer \& Staton's (2015) measure of judicial independence; and the Legatum Institute's Prosperity Index (i.e., a multi-pillar measure of prosperity that includes personal freedom, safety and security, environmental, economic, and other factors). Higher levels of the NIC are correlated with lower competitiveness, lower regulatory quality, lower ease of doing business, less judicial independence, and worse prosperity (see Figure 8). Based on Pearson's correlation test statistics, these relationships are significant. Even when controlling for income per capita, several retain their significance suggesting that these relationships are not just proxying for differences in development levels (see Appendix 3). The NIC is also negatively correlated with an IMF measure on tax collection efficiency ratio, but this relationship is not statistically significant.

\section{Stage 2: Event Studies}

\section{Following our theoretical framing, we construct a proxy for belief formation process} using the summation of changes in the NIC over time:

$$
\text { NIC Stock }{ }_{t}=\sum_{t_{0}}^{t} \Delta N I C
$$

In constructing the stock of changes in the NIC, we allow a 2-year lead-in for period 0 and the changes in the NIC are the first differences in logs. ${ }^{30}$ The same is done for the anti-NIC. Theoretically, we expect to see "scarring" from large shocks to the NIC Stock, not just

\footnotetext{
${ }^{30}$ For further clarification, we use 1995-96 as the lead-in period and use the sample period of 1997-2017 in our event studies and panels.
} 
marginal changes to the stock (i.e., the larger the change in t relative to the summation of changes up to $\mathrm{t}-1$, the larger the reassessment of beliefs about the state of underlying corruption in a country). In both the event studies and the panels, we proxy for such shocks using increases in economies' NIC Stocks that are more than two standard deviations above economy-specific means (NIC Shock $\left.{ }_{t}\right){ }^{31}$

\section{Event studies across different frequencies of the NIC suggest a negative impact of deteriorating corruption beliefs on several macro-outcomes. The below event studies} display the impact of the two standard deviation shocks, displaying period means in dots and three period moving averages in red lines, except for the annual figures where the red line tracks the period means. The data are balanced across the country-spells. ${ }^{32}$ Given the omitted variable bias inherent in such an exercise, causal interpretations cannot be made based solely on the event studies.

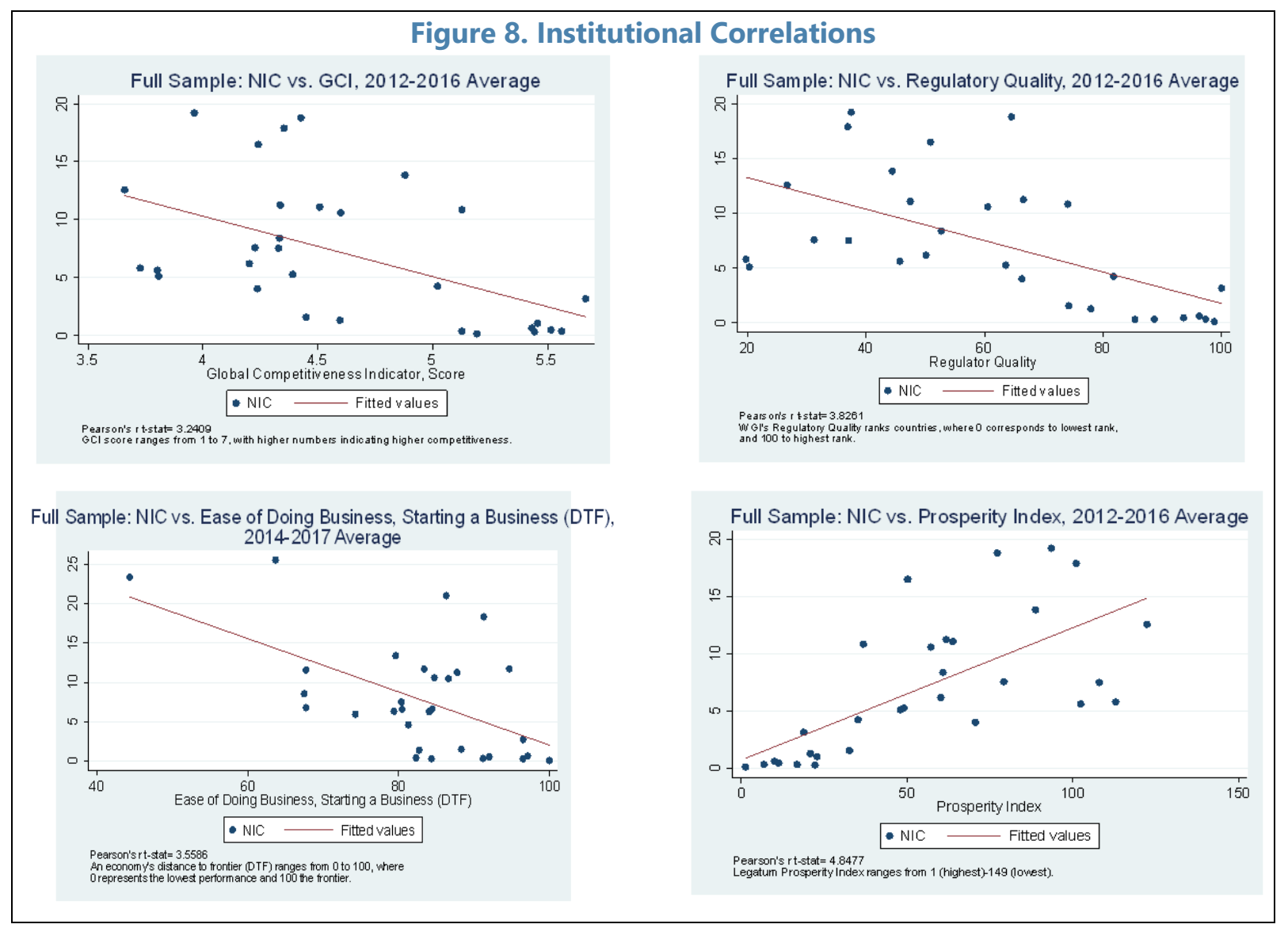

\footnotetext{
${ }^{31}$ While the monthly and quarterly shocks represent a broad range of scandals of varying magnitude; the annual shocks represent large-scale corruption scandals that would have been widely covered by international media for a prolonged period (e.g., the 1Malaysia Development Berhad scandal). In some instances, shock periods persist over multiple years. In these cases, the shock is identified as the first year. The annual shocks are distributed between both developing and advanced economies, including across Asia. Across the NIC and anti-NIC, there are 41 country-year shocks for the panels.

32 The above event study findings are qualitatively robust to using medians instead of country-spell sample means and there are 22 monthly, 33 quarterly, and 11 annual country-spells.
} 
Figure 8. Institutional Correlations (concluded)
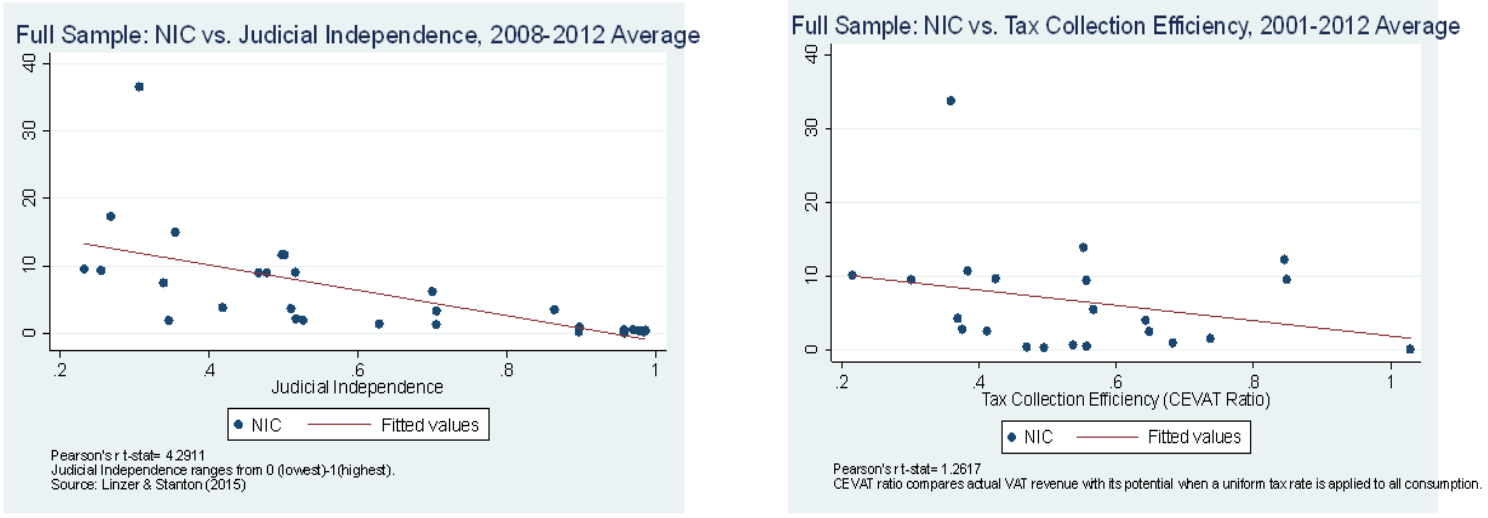

At a monthly frequency, stock market indicators point to a negative effect of deteriorating beliefs about the extent of corruption in a country. Abnormal returns are negative in the initial period before mean reversion to zero once the impact of the shock is priced in by investors (see Figure 9) ${ }^{33}$ Stock market volatility also significantly spikes in the aftermath of a NIC shock, remaining above the pre-period average for at least six months after the shock (see Figure 9). ${ }^{34}$ A likely channel for these effects is uncertainty. ${ }^{35}$ The fall in returns could also reflect lower expected future cash flows for firms, in line with Lee \& $\mathrm{Ng}$ (2009), who - adopting a firm-level analysis - show that firms in corrupt countries have lower expected profitability, and thus, lower corporate values than less corrupt countries.

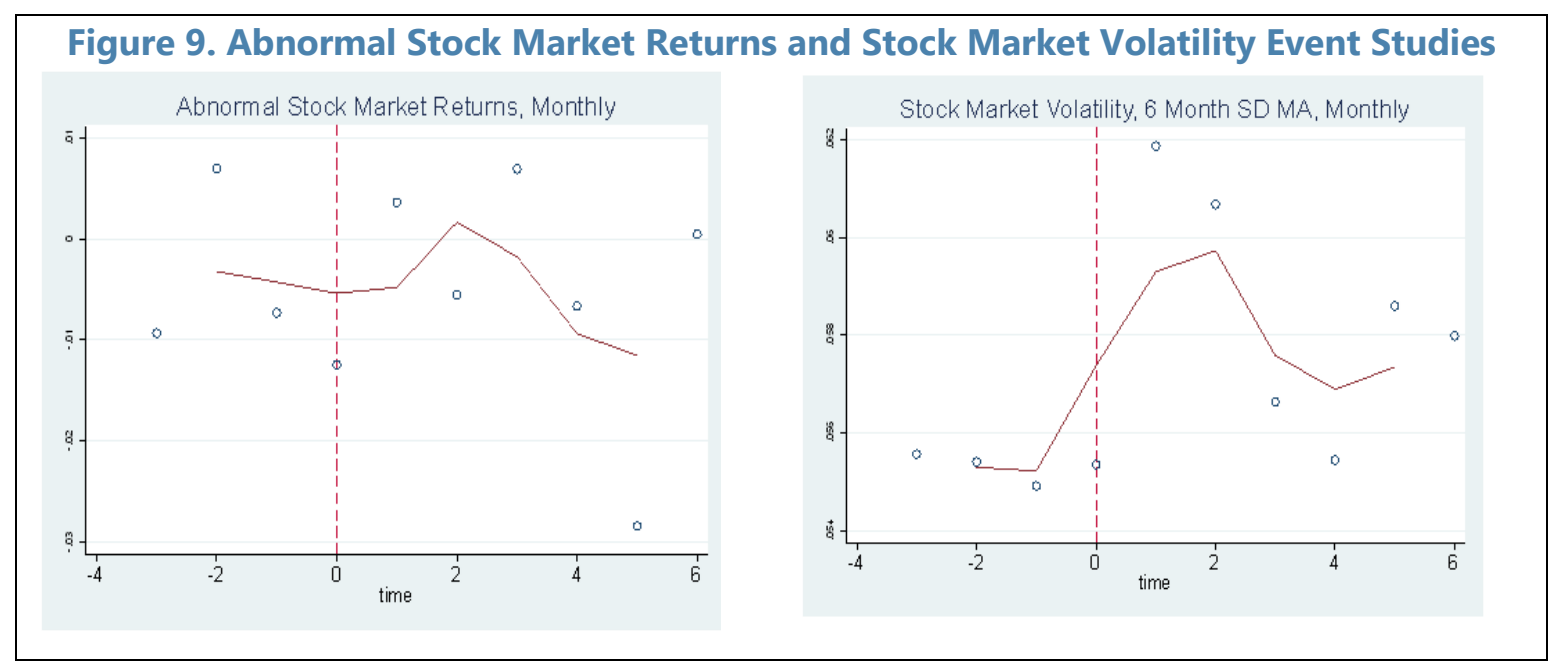

\footnotetext{
${ }^{33}$ Here abnormal returns are constructed using an adjusted constant mean approach where the estimation window is the entire sample period from 1995 to 2017.

${ }^{34} \mathrm{~T}$-tests comparing the pre- and post- period means are significant at the 10 percent level for stock market volatility ( $\mathrm{t}$-stat: 1.85), but not abnormal returns given the almost immediate mean reversion (as theoretically anticipated).

${ }^{35}$ For example, both Jeribi, et al. (2015) and Zaiane and Allita (2017) find that corruption-driven uncertainty shocks during the Arab Spring increased market volatility.
} 
Borrowing costs also tend to rise after a NIC shock, followed by considerable volatility (Figure 10) ${ }^{36}$ Ciocchini et al. (2002) show that more corruption translates into a higher risk premium in emerging markets; the same is likely to hold for news related shocks if the shock suggests more uncertainty and, thus, a higher risk premium. Recent anecdotal evidence in BRIC countries supports this literature.

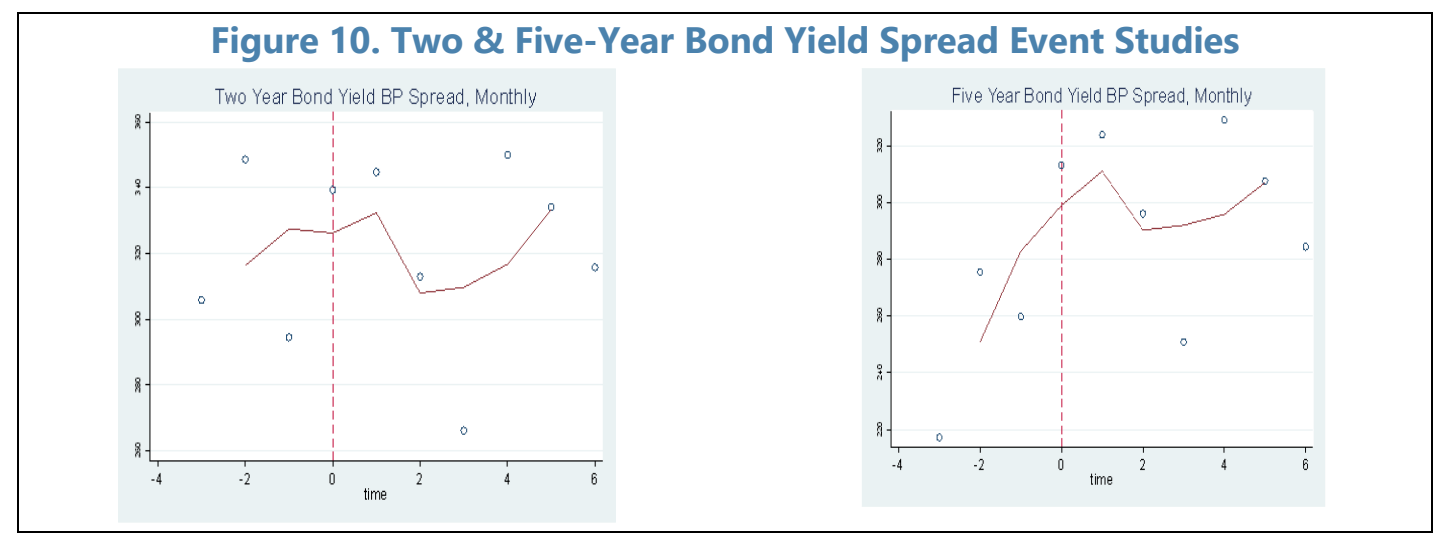

Nominal effective exchange rates tend to significantly depreciate (Figure 11). ${ }^{37}$ This could again relate to uncertainty, or to the expected impact of corruption on capital flows (Erhieyovwe and Onokero, 2013). Additionally, it could be driven by expectations - as Wei \& Wu (2001) find - that corruption evokes a portfolio shift towards riskier foreign bank lending as less foreign investment enters a country; this portfolio shift would put pressure on countries' currencies and increases the likelihood of a currency crisis. Expectations around a portfolio shift are aggravated by market expectations that international creditors are more likely to be bailed out than international direct investors, making banks more willing to do business in more corrupt countries than direct investors. ${ }^{38}$

\section{In our quarterly event studies, both} portfolio and FDI flows fall following NIC shocks, with a more negative level impact on portfolio flows and increased volatility for both outcomes (Figure 12). ${ }^{39}$ Based on Razin, et al.'s (1998) "pecking order of international capital flows," domestic investors have better information than international direct and portfolio investors, and international direct investors

\footnotetext{
${ }^{36}$ The pre/post t-test values are 0.35 and 2.61 for two- and five-year bond spread event studies, respectively.

37 The pre/post t-test value is 3.40 .

${ }^{38}$ Wei \& Wu (2002), p 467.

${ }^{39}$ While the pre/post test values are, respectively, 0.097 and 0.546 for portfolio flows and FDI, the pre/post t-stat for immediate period for portfolio flows is significantly lower (from $\mathrm{t}=0$ to 1 ). The same is not the case for FDI.
} 
have better information than international portfolio investors. In the context of this informational asymmetry, NIC shocks may have an outsized effect on the latter group, which is the most sensitive to news because it has the least information (as well as the most liquid assets).

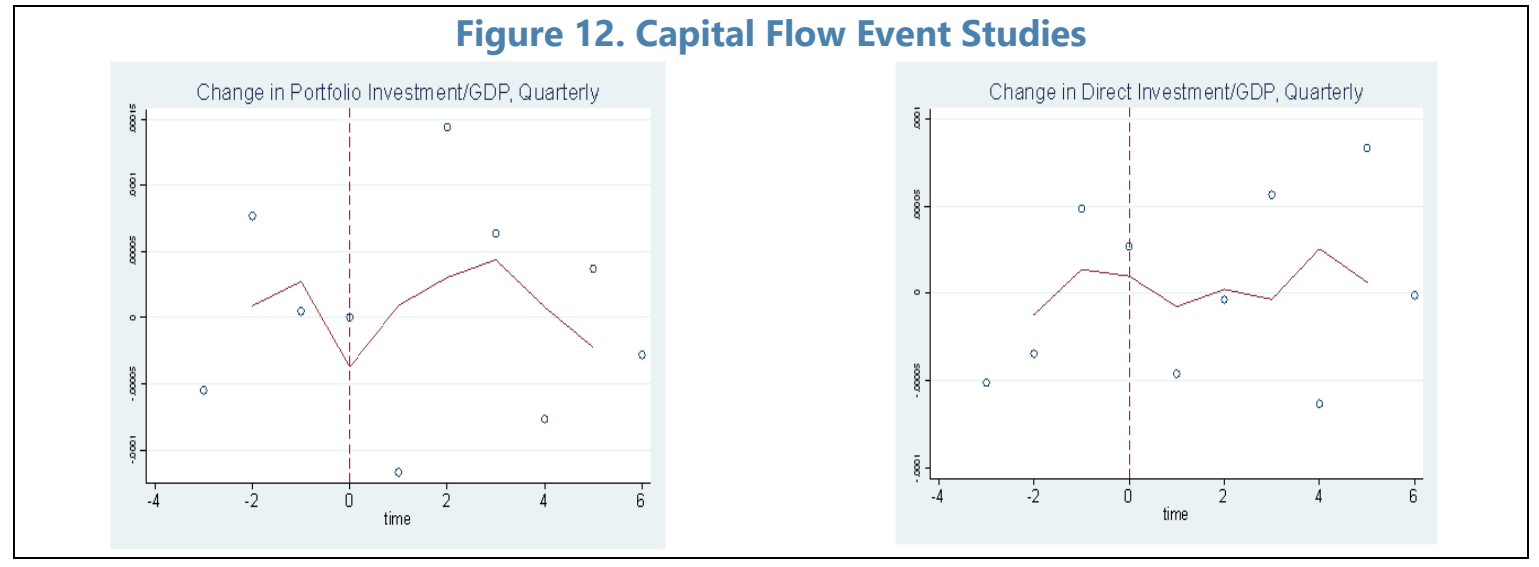

NIC shocks measured at annual frequency are correlated with a weakening of countries' fiscal positions (Figure 13) ${ }^{40}$ Following a corruption related news shock, tax compliance rates might drop, increasing tax evasion and resulting in lower tax revenues. Event studies on expenditure ratios do not show a structural break, suggesting that news could be of less importance to public expenditure. In contrast, corruption within public expenditure - such as in the context of large government procurement spending — constitutes an important and frequent source of news coverage as picked up by the NIC, i.e. not affected by, but triggering the analyzed NIC shocks.

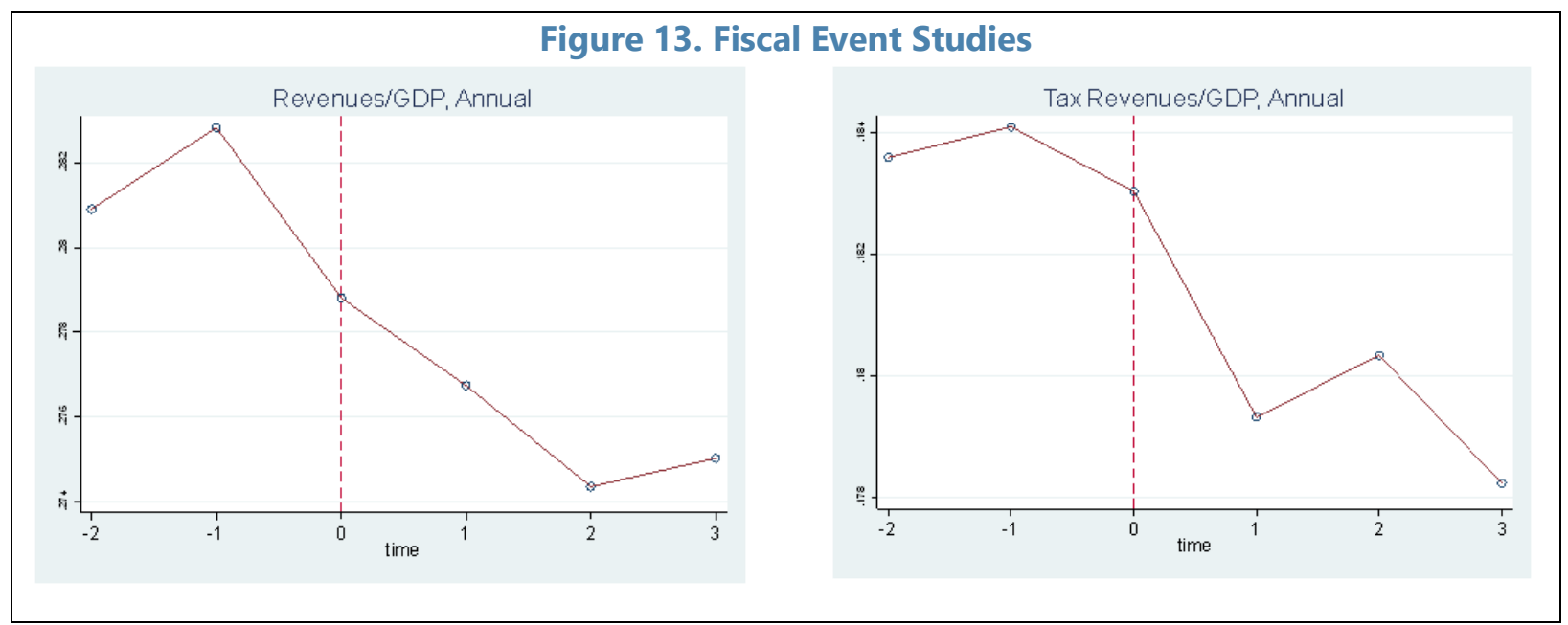

${ }^{40}$ The pre/post test values are all significant $(3.512,2.331,2.499$, and 2.888 for revenues, tax revenues, expenditures, and debt, respectively). 


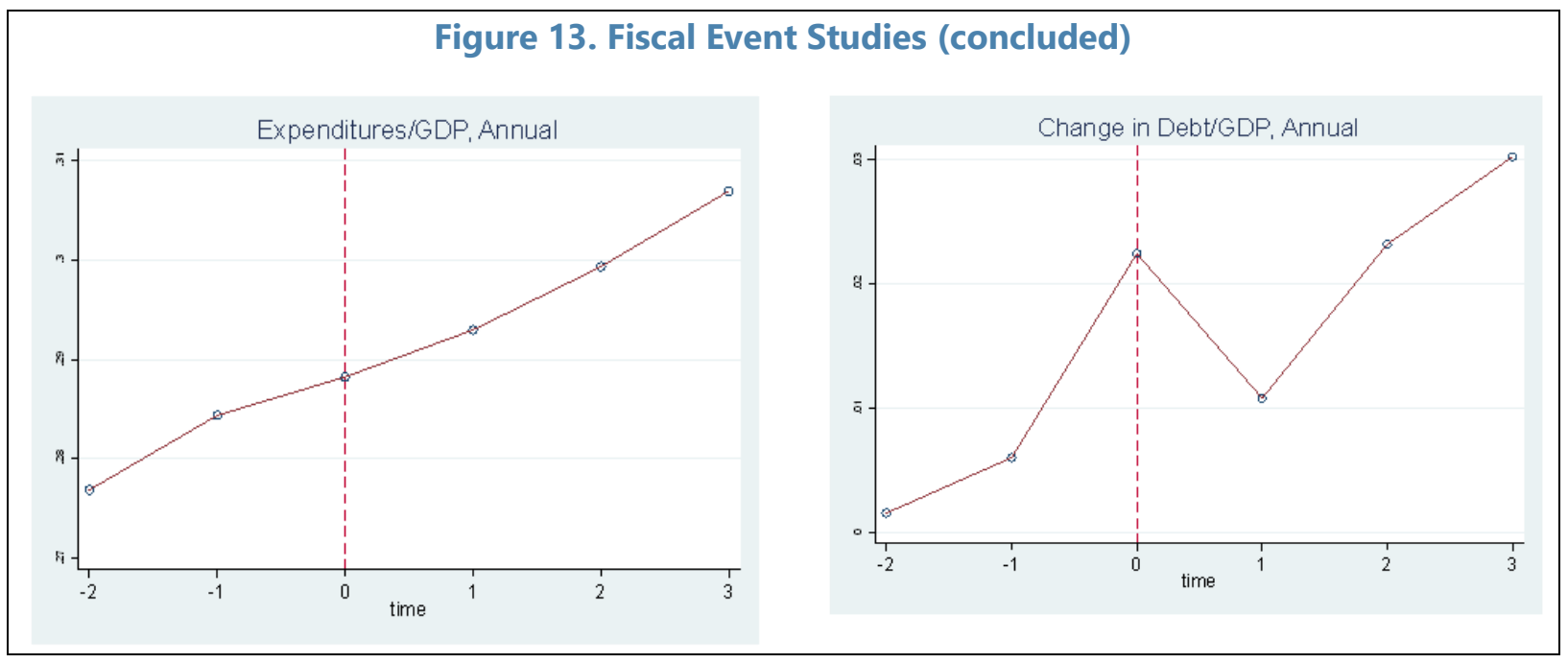

\section{Real GDP per capita growth is negative in the year following the shock and persistently} subdued thereafter (see Figure 14). ${ }^{41}$ As shown by the event studies, a news shock has the potential to impact many variables that could lead to lower growth; these include lower foreign direct investment, greater uncertainty, misallocation of resources, lower revenues, and many more.

Additionally, there may be longer run growth effects from feedback loops between the financial effects and real outcomes. For example, higher borrowing costs can lead to lower investment and growth; in turn, lower growth can increase the risk premium

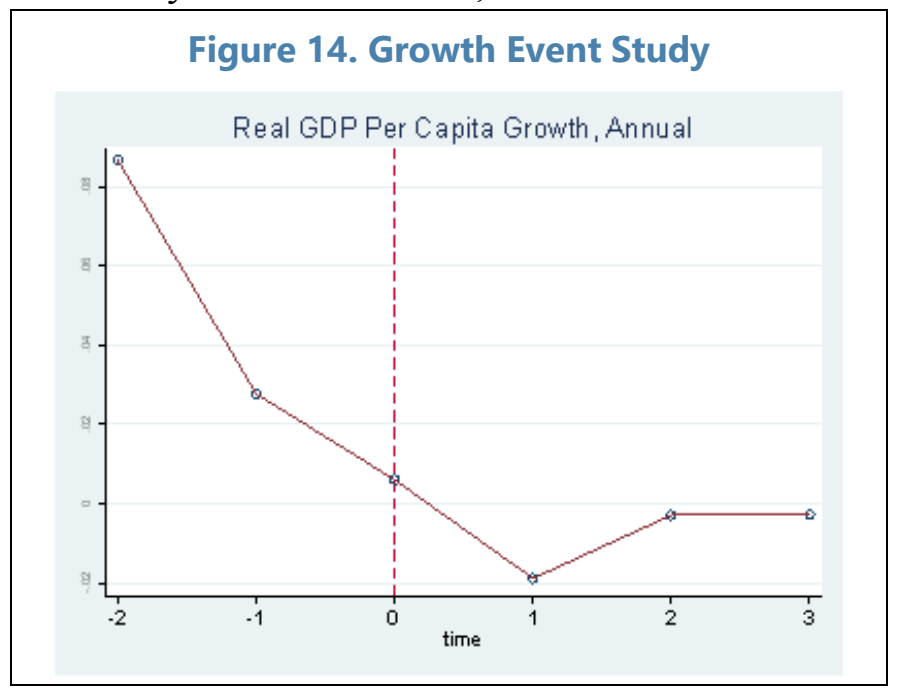
and lead to even higher borrowing costs. Suppressed growth following NIC shocks also helps explain the persistent deterioration in fiscal outcomes. ${ }^{42}$

\footnotetext{
${ }^{41}$ The pre/post t-test value is significant at 3.146.

42 As Sapienza \& Zingales (2012) noted: "One can bomb a country back to the Stone Age, destroy much of its human capital, and eliminate its political institution. But, if trust persists, the country may be able to right itself in just a few years, as in Germany and Japan after World War II. Conversely, you can endow a country with all the greatest natural resources but, if there is no trust, there is no progress."
} 


\section{Stage 3: Panel Estimations}

Panel estimations are a natural complement to the event studies and allow us to control for omitted variables, including the effect of anti-corruption campaigns. The above event studies, while suggestive, are far from conclusive evidence of the effects of changes in beliefs about corruption on macrorelevant outcomes. With panel estimations, we can control for several omitted variables (e.g., country and time fixed effects), in addition to addressing measurement error and other empirical hurdles. Moreover, the positive correlation between the NIC and antiNIC implies that at the same time as the NIC increases strongly, the anti-NIC tends to rise- - suggesting that authorities try to counter major corruption episodes (this is evidenced by the event study shown in Figure 15). ${ }^{43}$ To assess the

Figure 15. Anti-NIC Event Study

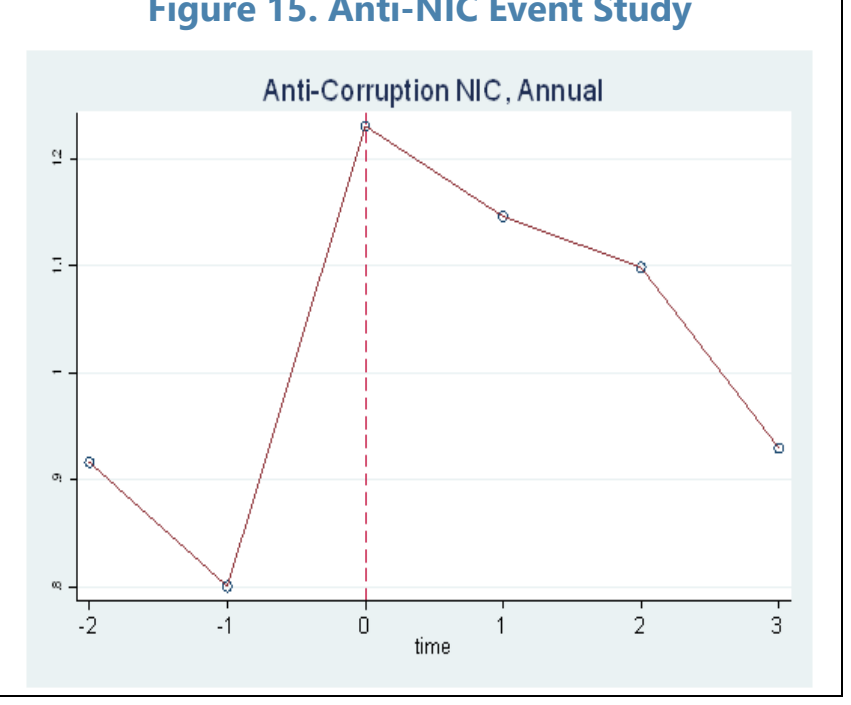
impact of NIC shocks, we also want to control for anti-NIC effects.

While panel estimations offer several benefits relative to event studies, concerns about measurement error, endogeneity, and other limitations may limit their usefulness. First, the NIC, while having a high signal-to-noise ratio based on the human audits, introduces measurement error. This would tend to attenuate our results, suggesting that our panel results are conservative estimates. Second, unlike other papers that tackle the empirical effects of corruption, we are less concerned about the endogeneity of the NIC measure. The underlying data is based on changes in news coverage and, as above-mentioned, one benefit of using a news-generated measure is that the industry is highly competitive and, to an extent, this raises the premium on accurate and timely reporting. This is especially true of international sources since they are less likely to be influenced by domestic political factions and less likely to be dependent on domestic resources for funding. ${ }^{44}$ Arguably, civil liberties could be a confounding variable that impacts both macro-outcomes and news coverage, but we adjust for that directly. ${ }^{45}$

In addition, dynamic panel equations introduce another source of endogeneity. Our panel specifications are dynamic panel fixed effects models (i.e., they call for the inclusion of lagged dependent variables), which introduce endogeneity via Nickell bias. The typical

\footnotetext{
${ }^{43}$ The pre/post t-test value is significant at 2.393 .

${ }^{44}$ To verify our prior, we also checked whether the NIC was correlated with elections and business cycles and did not find strong evidence of either relationship.

${ }^{45} \mathrm{We}$ also tried traditional instruments that are used in the corruption literature (e.g., measures of ethnic division, etc.) - and all were very weak in our setting (with insignificant first stage F-statistics) - they do not proxy news flow.
} 
prescription is to use Arellano-Bond GMM estimation and related techniques, however the number of countries is small in this case $(\mathrm{N}=30)$, making such approaches inappropriate. Thus, we run the OLS fixed effects models with and without the lagged dependent variable and assess the robustness of the results using both specifications.

In this section, we focus on the impact on growth. Paired with supportive evidence from the correlations and event studies, the panel results allow us to get a firmer sense of the macro-relevance of corruption across countries. Our generalized panel specification is as follows:

$$
y_{i t}=\alpha_{i}+\delta_{t}+\beta_{1} \text { NIC Shock } \text { Sht }+\beta_{2} \text { Anti-NIC Stock } \text { St }+\sum_{k \in K} \theta_{k} X_{i t}^{k}+\varepsilon_{i t}
$$

where:

- $y_{i t}$ is a macro-outcome;

- $\alpha_{i}$ are country fixed effects;

- $\delta_{t}$ are time fixed effects;

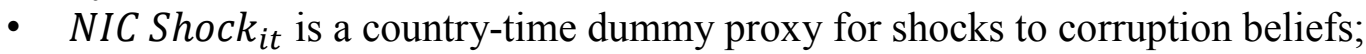

- Anti-NIC Stock it $_{\text {it }}$ is a country-time proxy for anti-corruption beliefs;

- $X_{i t}^{k}$ is a vector of standard logged control variables; ${ }^{46}$ and

- $\varepsilon_{i t}$ is the error term

Standard errors are clustered by country. ${ }^{47}$

NIC shocks have a significantly negative impact on real per capita growth. ${ }^{48}$ Negative NIC shocks lower real GDP per capita growth by roughly 2 percentage points concurrently and by 1 percentage point at a one-year lag, reflecting persistent effects from such shocks (see Table 3). ${ }^{49}$ The per capita growth results also hold when excluding the lagged dependent variables, controlling for changes in rule of law and government effectiveness, as well as controlling for level effects (the full panel results, as well as other robustness checks, can be found in Appendix 5). ${ }^{50}$ NIC shocks do not have significant effects on revenue/GDP and capital flows once we control for additional variables (see Appendix 5). Other studies have also failed to find strong relationships between corruption and FDI (e.g., Wheeler and Mody, 1992) and our event studies showed that capital flows were rather volatile following NIC

\footnotetext{
${ }^{46}$ Control variables (following the literature, e.g., Baunsgaard \& Keen, 2010 for Revenue/ GDP). For real per capita GDP growth estimations: inflation; change in openness; and change in exchange rate (also run with change in credit in robustness checks not shown). For revenue/GDP: inflation; GDP per capita; GDP per capita squared; and agricultural value-added share. For portfolio \& direct investment/GDP: inflation; exchange rate change; openness; and population growth.

${ }^{47}$ The main results are similarly significant if we use robust standard errors or cluster by time period instead.

${ }^{48}$ Using the simple NIC Stock as an alternative formulation in the panels produces insignificant results and confirms the theoretical lens - shifts in beliefs, with associated negative effects, occurs when there are large shocks, not simply marginal changes.

49 The magnitudes of these effects are adjusted for the ARDL structure of the specifications. Moreover, Jorda (2005) projection specifications (not shown here) also show significant results for two periods before the results become insignificant and trend towards zero. In such specification, the effect of NIC shocks is even larger, at -5 percentage points. ${ }^{50}$ Running the specifications without FE produced larger growth effects, suggesting that addressing omitted variable bias via the inclusion of FE is important.
} 
shocks. ${ }^{51}$ The coefficients on the anti-NIC stock variable are insignificant and likely reflect considerable heterogeneity in the size and quality of anti-corruption efforts across countries (which will be discussed in more depth below).

\begin{tabular}{|c|c|}
\hline \multicolumn{2}{|c|}{ Table 3. NIC Full Sample Results } \\
\hline & $\begin{array}{l}\text { Dependent Variable: } \\
\text { Real GDP Per Capita Growth }\end{array}$ \\
\hline \multirow[t]{2}{*}{ NIC Shock } & $-0.019 * \star$ \\
\hline & $(0.007)$ \\
\hline \multirow[t]{2}{*}{ NIC Shockt-1 } & $-0.011^{*}$ \\
\hline & $(0.005)$ \\
\hline \multirow[t]{2}{*}{ Anti-NIC Stock } & -0.001 \\
\hline & $(0.003)$ \\
\hline Observations & 596 \\
\hline Adjusted R-squared & 0.937 \\
\hline Country \& Year FE & Yes \\
\hline Full Set of Controls \& Lagged Dependent Variables & Yes \\
\hline
\end{tabular}

There is considerable heterogeneity in the impact of NIC shocks on real per capita GDP growth across advanced economies vs. emerging markets and developing economies (EMDEs) and high and low NIC economies. In Table 4, we run the specifications on subsamples. NIC shocks in advanced economies have a smaller and insignificant impact compared to EMDEs in our sample (columns (1)-(2), Table 4). The second comparison we explore is between high and low NIC economies to examine non-linearity in the effect of NIC shocks. Countries with a mean NIC above the sample's $75^{\text {th }}$ percentile level are classified as "high" and countries with a mean NIC below the $25^{\text {th }}$ percentile are classified as "low." The negative impact seen in the full panel are driven by countries that have high NIC averages; the impact of belief shocks on low NIC countries is insignificant (column (3)-(4), Table 4). ${ }^{52}$ Based on the institutional correlations in Figure 8, high NIC countries tend to have low institutional quality. In light of this, and based on the trust literature discussed in Section II, when shocks occur in high NIC countries, agents may have less trust that governments will successfully counter the issue leading to larger belief shifts and lingering

\footnotetext{
${ }^{51}$ We also ran the capital flow specifications on quarterly data; the results are similarly insignificant.

52 The standard errors in these specifications are computed based on seven clusters, which may introduce a "too few cluster" issue. However, using bootstrapped or jackknifed standard errors also produces significant results (at the 5 percent level).
} 
growth effects. However, in low NIC countries, agents might expect the authorities to efficiently and effectively address the outage. ${ }^{53}$ Finally, the shocks also differ in magnitude across advanced and EMDEs, with the latter group having larger standard deviations in their NIC Stocks. These results are robust to excluding the lagged dependent variable (see Appendix 5). ${ }^{54}$

\begin{tabular}{|c|c|c|c|c|}
\hline & (1) & (2) & (3) & (4) \\
\hline $\begin{array}{l}\text { Dependent Variable: Real GDP Per } \\
\text { Capita Growth }\end{array}$ & Advanced & EMDEs & $\begin{array}{l}\text { High NIC } \\
\quad\left(>75^{\text {th }}\right. \\
\text { Percentile })\end{array}$ & $\begin{array}{c}\text { Low NIC } \\
\quad\left(<25^{\text {th }}\right. \\
\text { Percentile })\end{array}$ \\
\hline \multirow[t]{2}{*}{ NIC Shock } & -0.009 & $-0.023^{*}$ & $-0.028^{* * *}$ & -0.002 \\
\hline & $(0.007)$ & $(0.012)$ & $(0.007)$ & $(0.006)$ \\
\hline \multirow[t]{2}{*}{ NIC Shockt ${ }_{t-1}$} & -0.007 & -0.012 & $-0.019 * *$ & -0.006 \\
\hline & $(0.007)$ & $(0.008)$ & $(0.007)$ & $(0.010)$ \\
\hline Observations & 220 & 376 & 140 & 140 \\
\hline Adjusted R-squared & 0.890 & 0.944 & 0.967 & 0.924 \\
\hline Country and Year FE & Yes & Yes & Yes & Yes \\
\hline $\begin{array}{l}\text { Full Set of Controls \& Lagged } \\
\text { Dependent Variables }\end{array}$ & Yes & Yes & Yes & Yes \\
\hline
\end{tabular}

\section{The findings suggest that corruption belief shocks are macro-relevant for growth} prospects in EMDEs and economies with corruption vulnerabilities. Advanced, low NIC economies do not appear to face sizable growth implications from country-specific shocks. There are several explanations for what might be driving this result. Such countries tend to have stronger and more resilient institutions, but economies' time invariant structural

\footnotetext{
${ }^{53}$ Ideally, one could control for this directly. However, the current databases of trust (e.g., the OECD's Trust Database) do not cover many of our sample countries.

${ }^{54} \mathrm{We}$ also examined the impact of NIC shocks on commodity-exporting countries relative to others. We find that NIC shocks significantly and negatively impact non-commodity exporters, while the result on commodity exporters is insignificant. This is an interesting juxtaposition; however, we do not place too much emphasis on the finding given the small set of commodity exporters within our broader sample country set.
} 
characteristics should be controlled for with the fixed effects. ${ }^{55}$ An alternative explanation may be that the frequency and size of NIC shocks in these countries are limited, and that anticorruption news flow counteracts the shift in belief formation (see next section). The insignificance of the capital flow results can likely be ascribed to the use of annual data in the panels; capital markets respond quickly to news shocks. However, use of the higher frequency NIC in a panel setting was limited by poor control data availability for the emerging and low-income countries in our sample at higher frequencies. More work is needed to empirically detect the channels through which belief changes - as proxied by NIC shocks - impact growth outcomes in EMDEs with higher NIC levels.

\section{Anti-Corruption EFForts-Selected Country CASE Studies, Use of TECHNOLOGY AND THE ROLE OF CAPACITY DEVELOPMENT}

In light of the negative effects of corruption belief shocks, this section takes a closer look at anti-corruption (AC) efforts and meaningful measures countries can take to address corruption. Given the findings of the previous sections of the paper, which show a negative impact of news flow on corruption on borrowing costs, exchange rates, stock market returns, capital flows, fiscal balances, and growth, one would expect that anti-corruption measures generate an orthogonal impact on macro outcomes; however, the panel results do not support this assertion. To gauge the effect of AC efforts, we present selected event studies, panel results, and case studies.

\section{A. Anti-Corruption in the Context of Belief Formation}

Like the NIC, the impact of anti-corruption news flow can be viewed through the lens of belief formation, via two different channels. By construction, a higher anti-NIC reflects relatively more news about anti-corruption efforts in a country. Within the belief formation process outlined earlier, large shocks to the NIC shift beliefs about the prevalence of corruption more persistently. Only over time, as the shock lessens, will behaviors re-adjust to equilibrium. News on anti-corruption, however, could affect this process and could help to accelerate the re-adjustment. So on the one hand, anti-corruption news could shift beliefs on the prevalence of corruption, particulary following a shock to the NIC, and could therefore yield positive economic outcomes. On the other hand, such news is usually associated with concrete actions being brought against individuals or institutions. Once AC efforts - as picked up by news - bear fruit and actually reduce corruption - possibly over the more medium- to long-term following persistent efforts - this could help to lower the levels of the NIC and could reduce the frequency or amplitude of shocks to the NIC. Persistent anticorruption news flow could therefore yield positive economic outcomes indirectly via its effects on the NIC.

\footnotetext{
${ }^{55}$ As discussed in the literature review, prior literature has found non-linear relationships between growth and corruption due to differences in institutional quality and type/setting (e.g., democratic vs. autocratic regimes or the level of economic freedom). For an example, see Heckelman and Powell (2010).
} 


\section{B. Effectiveness of Anti-Corruption Efforts}

Event study results show some positive impact from shocks to the anti-corruption news

flow on macro outcomes. Following shocks to the anti-NIC, our event studies show a positive impact on financial variables, such as decreasing stock market volatility and appreciating exchange rates (see Figure 16). ${ }^{56}$ However, longer-run responses, exemplified here by changes in portfolio investment-to-GDP or debt-to-GDP are more muted-and similar findings hold for other macro outcomes.

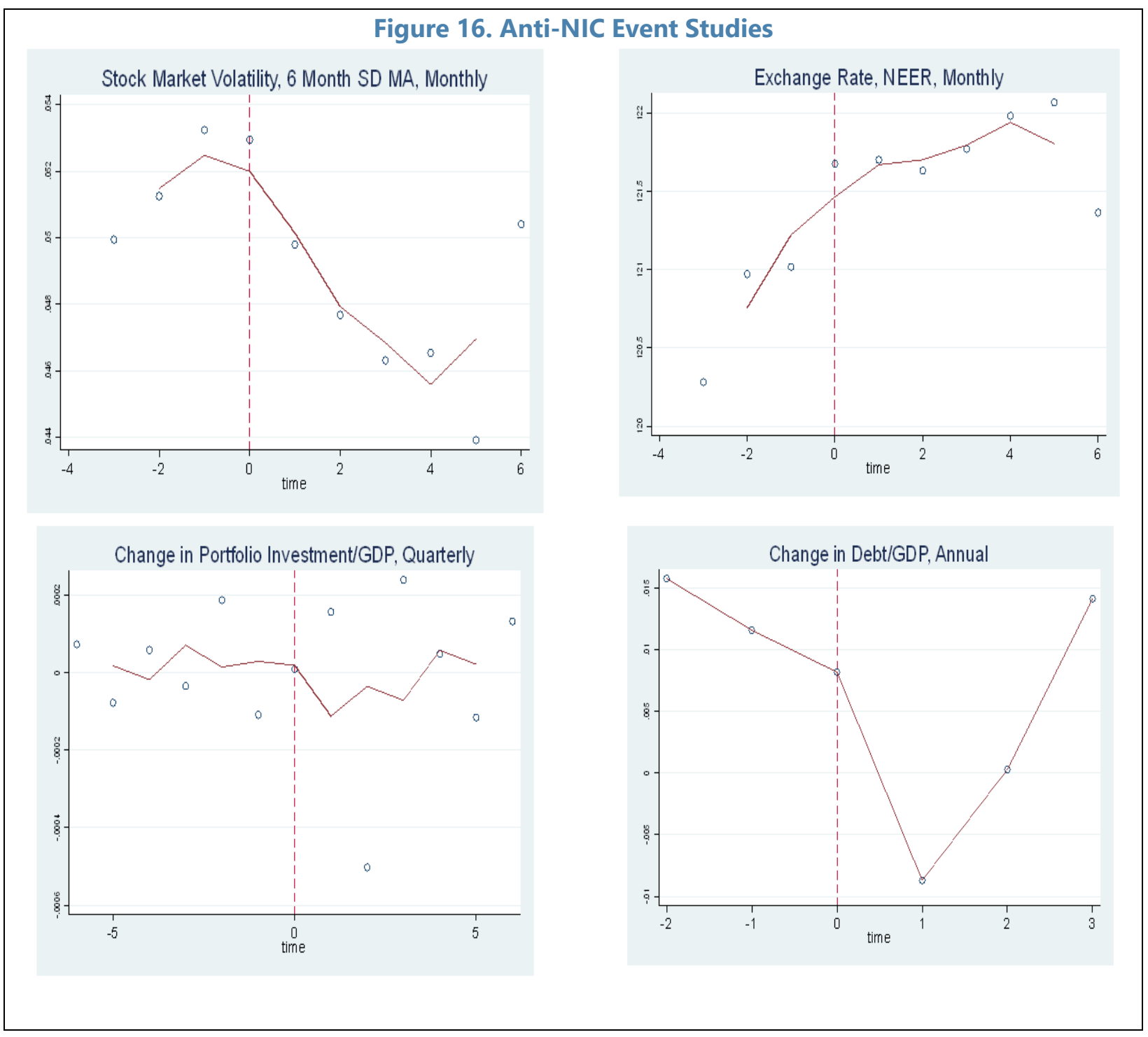

${ }^{56}$ For the construction of these event studies, see section IV. B. The pre/post t-test results for stock market volatility, exchange rate movements, and change in debt/GDP are significant at 4.946, 1.713, 1.352, respectively. Change in portfolio flows/GDP are insignificant, even when comparing the immediate post-shock period to the rest of the event window. 
In panel estimations, anti-NIC shocks have an insignifcant impact on real GDP per capita growth (Table 5). Moreover, the sign on the coefficent in the concurrent period runs counter to theoretical expectations..$^{57}$

\section{Table 5. Anti-NIC Full Sample Results}

\begin{tabular}{|c|c|}
\hline & $\begin{array}{l}\text { Dependent Variable: } \\
\text { Real GDP Per Capita Growth }\end{array}$ \\
\hline \multirow[t]{2}{*}{ Anti-NIC Shock } & -0.005 \\
\hline & $(0.008)$ \\
\hline \multirow[t]{2}{*}{ Anti-NIC Shockt-1 } & 0.002 \\
\hline & $(0.005)$ \\
\hline \multirow[t]{2}{*}{ NIC Stock } & -0.004 \\
\hline & $(0.004)$ \\
\hline Observations & 596 \\
\hline Adjusted R-squared & 0.936 \\
\hline Country \& Year FE & Yes \\
\hline Full Set of Controls \& Lagged Dependent Variables & Yes \\
\hline
\end{tabular}

\section{But persistent anti-corruption news flow} is correlated with lower NIC levels. We consider 3-year episodes of anti-corruption news flow, and split these episodes into quintiles from consistently lowest to consistently highest news flow (Figure 17). For the fourth and fifth quintiles - those country-episodes with the most persistent anti-corruption news flow-we find a reduction in the NIC five years later. ${ }^{58}$ Yet the magnitude of this reduction is relatively limited and does not give insight into longer-run trends. It also does not establish

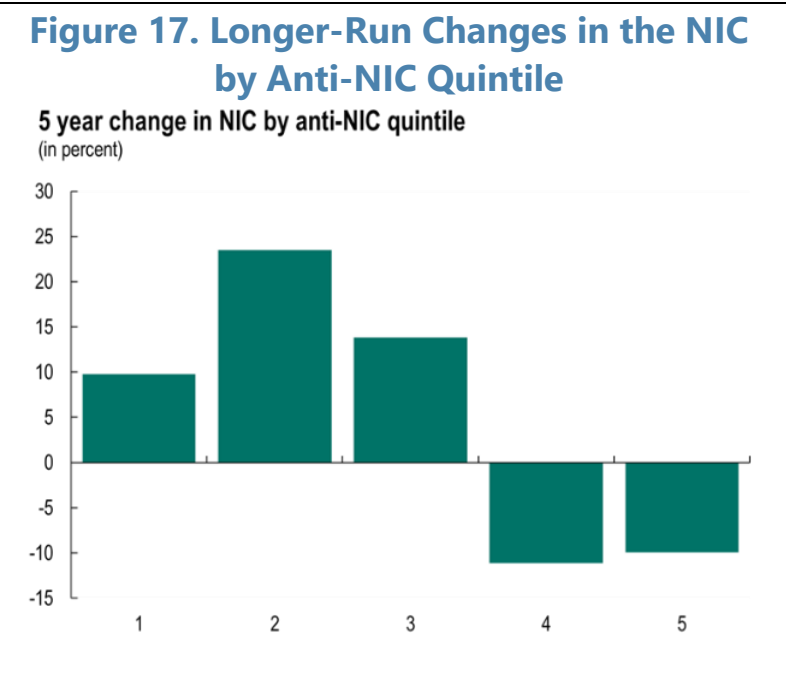

${ }^{57}$ This may reflect a lack of trust in authorities' efforts to combat corruption; Rizzica \& Tonello (2018) find evidence of this chanel in the Italian context.

${ }^{58}$ To test whether these results are driven by cases in which the NIC increased before the anti-NIC episode and the reduction in the NIC simply implies a move back to its original values, we drop these cases. The findings are broadly similar. 
any causal relationship, and the drop in the NIC could be driven by factors other than the anti-NIC. But the fact that the anti-NIC seems to be linked to a reduction of the NIC suggests an indirect impact from AC efforts on macro outcomes by reducing the NIC.

The mixed nature of the empirical findings on the anti-NIC suggests that the indirect channel-from persistent anti-corruption news flow based on steady AC efforts to lower corruption news flow - might be most relevant. Hence, the quality and duration of $\mathrm{AC}$ policies is of importance. While corruption scandals as picked up by the news tend to be rather homogenous in nature (i.e., they tend to be standard instances of high-ranking senior officials' abusing their posts for private gain), anti-corruption efforts and the related news flow vary greatly. In addition to the heterogenous nature of anti-corruption news and related $\mathrm{AC}$ policies, overall progress in combating corruption as measured by the news has been limited (as shown in Figure 4).

\section{Anti-Corruption Interventions}

The weak effects of the anti-NIC shocks suggest that for beliefs to shift, with associated economic gains, governments must do more than engage in cheap talk. Anti-corruption efforts must be supported by meaningful policy changes and governance vulnerabilities should be addressed in a holistic and sustainable manner. In addition, AC strategies should reflect the country specific context. How can countries set-up an anti-corruption framework? This section considers two avenues: the more traditional AC recommendations, as well as more recent ideas with promising potential to holistically address corruption: modern technology and capacity development.

\section{Traditional frameworks}

The first generation of AC frameworks has largely been focused on theoretical models such as the the principal-agent model of corruption - which was first formalized by Klitgaard (1988). It is built around asymmetric information between a principal and agent; the actions of the agent - based on microeconomic utility theory - lead to negative externalities for the principal. ${ }^{59}$ The implications of this model indicate that AC frameworks should focus on higher likelihood and higher penalties of getting caught, reducing discretion of agents, enhancing transparency, and other measures reducing the agent's utility of corruption. Other literature tends to view corruption as a collective action problem (see Persson et al., 2010, Marquette and Peiffer, 2015) or as a "greasing the wheel" second-best solution to economic and structural problems that arise either due to overregulation or weak institutional environments (Marquette and Peiffer, 2015). They necessitate providing solutions to these underlying economic, structural, or political problems.

\footnotetext{
${ }^{59}$ At least two different principal-agent relationships can be thought of: a political leader as the principal and a bureaucrat as agent; alternatively, citizens as the principal and political leaders as agents.
} 
Qualitative case studies may prove useful to show characteristics of successful anticorruption efforts. We examine the evolution of AC efforts in countries with some of the largest average anti-NICs in our sample_-Indonesia and Malaysia.

- In Indonesia, after the collapse of the Suharto regime, and amid domestic and international pressure, several anti-corruption measures were implemented from 2002 onwards. One of the cornerstones of the anti-corruption law was the founding of the AntiCorruption Commission (KPK) in 2003. The establishment of the Commission was also a structural benchmark in the IMF's 2000-03 EFF program with Indonesia. Transparency International and several other studies have mentioned the KPK as a best practice example for anti-corruption commissions (TI, 2013; Bolongaita, 2010).

- The KPK is a fully independent institution with strong powers and a broad mandate to investigate, prosecute, prevent, and educate. ${ }^{60}$ The agency's success — which includes many high-profile arrests - has made it one of the most credible and trusted institutions in Indonesia (Kuris, 2012). Its independence is enshrined in law and was in the past upheld by Indonesia's Constitutional Court; but there are recurring efforts to revise the KPK law (TI, 2013; Abbott, 2017).

- Over the last decade, compared to the sample average, Indonesia's anti-NIC measure has picked up a significantly higher anti-corruption news coverage (Figure 18). Following major gains made on AC efforts, the NIC has improved - after an initial steep rise-and the gap between Indonesia's NIC and the NIC sample average has narrowed.

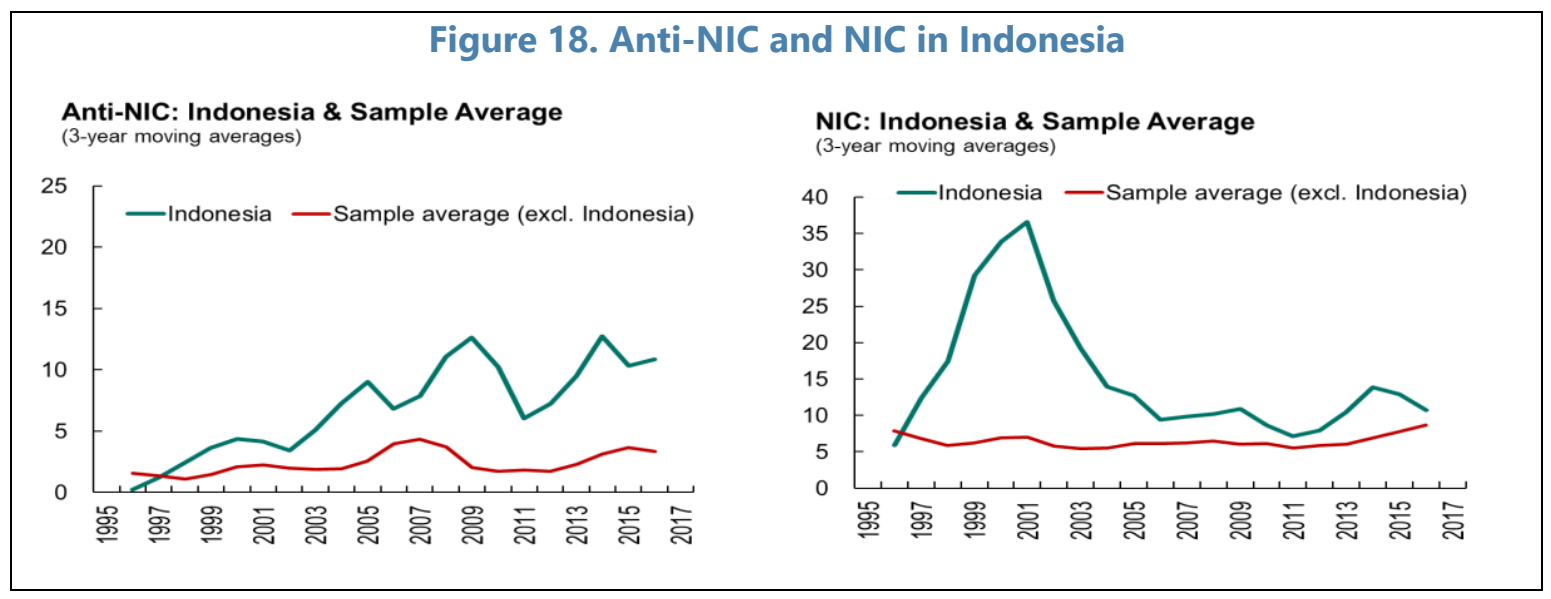

- Malaysia implemented anti-corruption laws and set-up an anti-corruption commission back in the 1960s, earlier than many other countries in the region. Qualitative analysis and agency performance data suggest the commission's work has been relatively

\footnotetext{
${ }^{60}$ The KPK has the authority to investigate corruption cases, including the right to tap communication lines, ban individuals from leaving the country, freeze bank assets, and conduct wealth checks of government officials. As part of its prosecution responsibilities, it can prosecute corruption cases and assume cases for prosecution by other law enforcement agencies. It offers anti-corruption education and promotes public awareness campaigns. To remain incorruptible, the KPK offers competitive salaries and has implemented a well-functioning performance measurement system (TI, 2013).
} 
successful (Meagher, 2005; Quah, 2001). The laws and the commission have been reformed over time; the current commission, the MACC, replaced its predecessors as part of the Malaysian Anti-Corruption Commission Act 2009. Compared to Indonesia's KPK, the MACC has investigative, preventive, and educational powers, but no independent prosecutorial power; the decision to prosecute is left to the politically-appointed Attorney General (TI Malaysia, 2014).

- In addition, the Malaysian government has continuously worked on anti-corruption efforts and initiatives beyond the scope of the commission, such as initiatives of clean, efficient, and trustworthy government, the introduction of e-government, the National Integrity Plan introduced in 2004, or the Government Transformation Program in 2009 which included features such as the introduction of the Whistleblower Protection Act 2010, Special Courts on Corruption, and the setup of the electronic "MyProcurement" portal (see Siddiquee, 2009 or Hershman, 2016 for more examples).

- Overall, Malaysia is regarded as one of the few countries in Asia that has over time managed to reduce corruption (Quah 2001; Siddiquee 2009). This also shows up in its NIC measure, which was lower than the sample average for most of the sample period. However recently, as the 1MDB scandal has dominated the news coverage, both the NIC and anti-NIC picked up (Figure 19). ${ }^{61}$

Figure 19. Anti-NIC and NIC in Malaysia
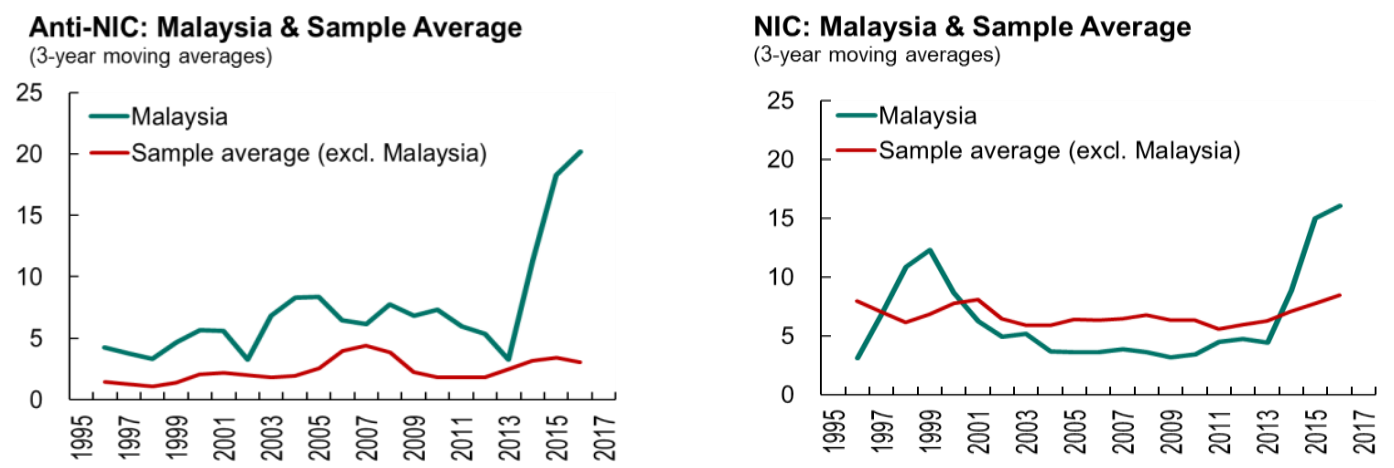

A strong and independent anti-corruption commission in Indonesia and a relatively comprehensive and long-lasting anti-corruption strategy in Malaysia have helped the countries to achieve relatively low levels of the NIC. Both cases exemplify how various country-specific anti-corruption measures can provide a successful starting point for an AC framework. In Indonesia, the implementation of the anti-corruption law was more likely given the specific circumstances at the time: a severe economic and political crisis, the commitment of reformers in the post-Suharto government, society's upheaval against corruption, and donors building in safeguards for their financial assistance, while providing

${ }^{61} 1$ Malaysia Development Berhad (1MDB), a state-owned investment fund, has faced corruption and mismanagement allegations, resulting in large-scale, ongoing local and global investigations. 
capacity development on drafting the anti-corruption law (Bolongaita, 2010; Klitgaard, 2015). Adding to these two cases, Singapore provides an example of a holistic AC framework (see Box 2).

\section{Box 2. Singapore: The Development of a Holistic Anti-Corruption Strategy}

Singapore's successful fight against corruption can be attributed to a stringent anti-corruption framework, supported by strong political will and the development of an anti-corruption culture over time. As shown by the NIC, Singapore has had considerably lower corruption than the sample average. But corruption was widespread during colonial times, and before an anti-corruption strategy was adopted in 1959 (see Koh, 2011). Besides the implementation of the anti-corruption framework, other factors were important on the road to low corruption. First, political will has been a key ingredient to success (see Quah, 1988). Second, the country developed a zero-tolerance philosophy and, over time, was able to create a culture that eschews corruption, with confidence that rules are transparent and applied fairly (Lee, 2016).

Singapore implemented a comprehensive anti-corruption framework with four main pillars: an independent judiciary, stringent laws, effective enforcement, and a responsive administration. An anti-corruption agency - the Corrupt Practices Investigation Bureau (CPIB) - was established in 1952; it is an independent agency which reports directly to the Prime Minister. It investigates and prosecutes corruption, and has considerable power to arrest and search people. Stringent laws, their enforcement, and an efficient administration ensure that corruption moved from a low risk, high reward activity to high risk, low reward.

Tough laws and effective enforcement increase the risk of being corrupt (i.e. risk of being caught and punished). The Prevention of Corruption Act (PCA) was enacted in 1960, and is revised regularly to ensure its effectiveness (CPIB, 2016). It allows the investigation of corruption in both the public and private sector, and from a bribe giver and receiver perspective. An accused must provide proof that wealth was acquired legally, and high penalties in the form of fines or prison terms assure that offenders do not enjoy any gains from corruption. The independent and well-resourced anti-corruption agency CPIB is the only agency empowered to investigate corruption, and has not shied away from investigating senior officials.

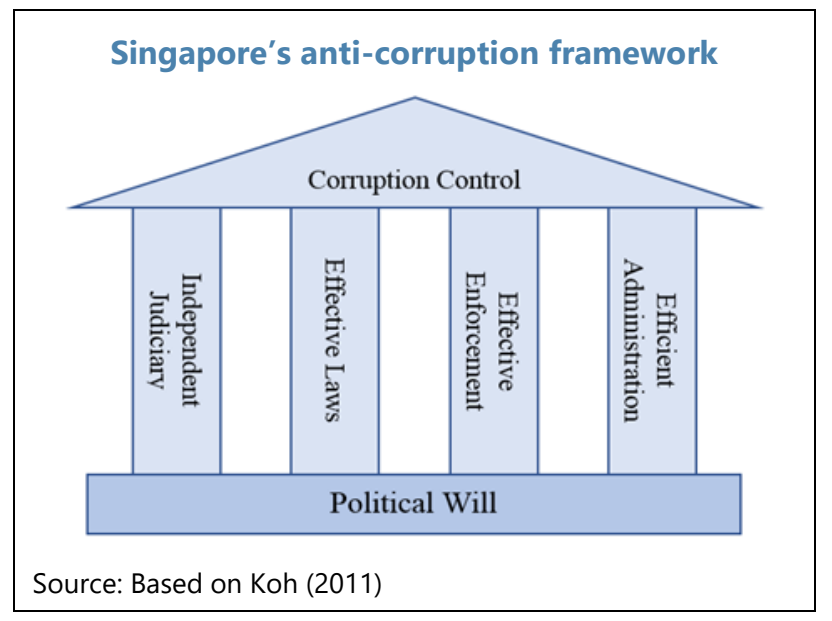

Some of the main sources of corruption in the public sector-low salaries and ample opportunitieshave been addressed to ensure an efficient administration and good governance. Salaries of politicians and civil servants in Singapore are high and benchmarked to the private sector to reduce the economic incentive for corruption, and to attract and retain a talented and honest public workforce (Berlinger, 2012). There are strict regulations governing the conduct of the public administration, including regular mandatory declarations of assets for each public officer, caps on an officer's unsecured debt and liabilities, and required approval for engaging in any trade or business. Administrative procedures have been streamlined and red tape removed to ensure transparent and quick procedures that do not require corrupt civil servants to make decisions (Koh, 2011). In addition, the CPIB conducts public outreach to influence social norms and to raise awareness, set up a Complaints Evaluation Committee, and whistle-blowing policies in many public and private entities promote disclosure. 
Box 2. Singapore: The Development of a Holistic Anti-Corruption Strategy (concluded)

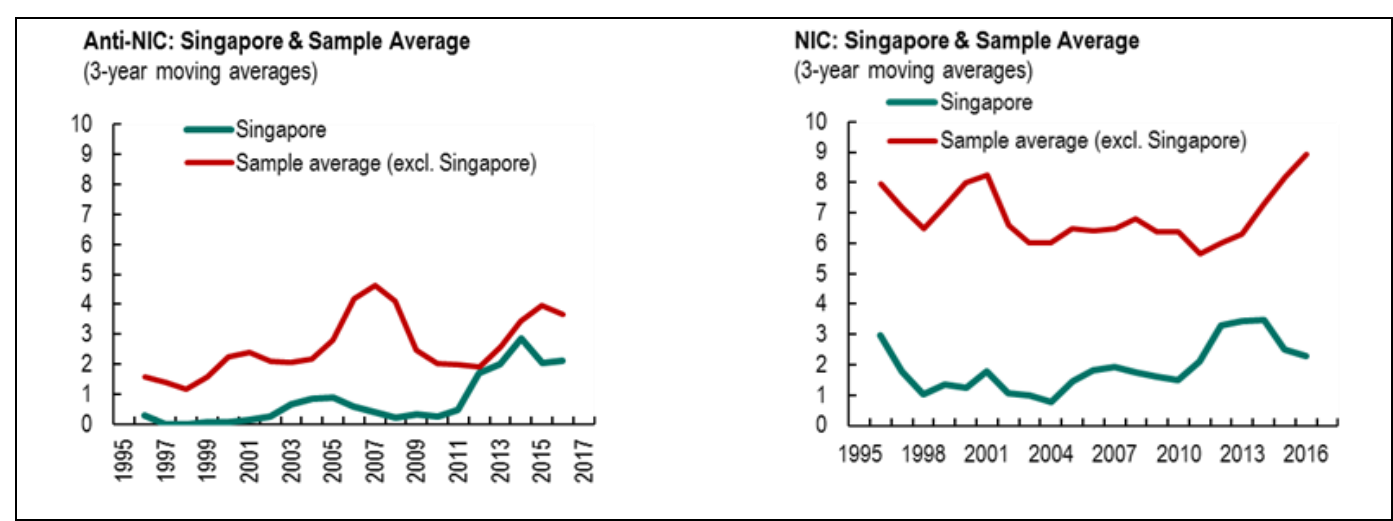

Key Lessons: Any AC framework requires constant effort and ongoing refinements of the anti-corruption strategy to keep corruption low and develop an anti-corruption culture within society. Singapore's specific characteristics-colonial institutions, its small size, independence from Britain and a new Constitution at the time of implementation of first anti-corruption measures, and a conservative culture-limit the transferability of their reform efforts to other countries, but rather point to the necessity of country-specific tailored measures. Addressing petty corruption within the civil service by paying fair salaries and removing red tape could be relatively low-hanging fruits that might not only reduce corruption, but could also improve the overall business environment; modern technology could provide support.

\section{Closing the Gap: 21st Century Anti-Corruption Interventions}

\section{Among further AC measures, governments have recently begun using modern} technology to support anti-corruption efforts. Information technology is increasingly viewed as the new frontier for a successful AC framework. Profound transformations powered by IT are expected to address corruption in many ways. The introduction of digitalization in a broader sense in the public sector is an innovative solution to make it more efficient, modern and provide more dynamic working methods that could potentially prove to be a major force in the global war on corruption (see Box 3).

\section{Secondly, ongoing work on capacity development (CD) could be an important support} element of AC frameworks. CD can help to focus countries' development agendas on institutional strengthening which could help minimize governance and corruption problems. To proxy for capacity development initiatives, we consider CD as provided by the IMF. Although the IMF's CD is not directly designed to address corruption, it intervenes in areas that are relevant for anti-corruption efforts such as fiscal governance, AML/CFT and financial sector supervision. 
Improvement in these areas can help usher in more strengthened and inclusive institutions and thereby contribute to minimizing tendencies toward corruption and encouraging growth (see Box 4). ${ }^{62}$

There is a positive correlation between the amount of IMF CD that countries have received in the last decade and the improvement in the news flow of corruption (Figure 20). Our three case studies (Indonesia, Philippines and Nepal) where IMF CD has been intensive over the last decade show that $\mathrm{CD}$ intervention is closely associated with improvements in their broad macroeconomic aggregates as well as other indicators that measure institutional strength and perceptions of corruption.

\section{To explore the impact of CD efforts on growth and how such efforts interact} with the anti-NIC, we run panel estimations using a constructed IMF dataset of Technical Assistance Field Time Estimates (FTEs) ${ }^{63}$ for our sample countries over the period 2007-17. Panel estimates show that when anti-NIC shocks are coupled with $\mathrm{CD}$, they reinforce one another leading to large gains (see Table 6). At a 1-year lag, an additional FTE of CD increases growth by an average of 0.8 percentage points; at a 2 -year lag, the growth increases by 3 percentage points if additional CD is coupled with anti-corruption efforts. ${ }^{64}$ While encouraging, these results are not conclusive; the measure used here does not distinguish between the quality of CD and the results are sensitive to specification. Future research might explore more nuanced measures of CD. Still, there is support evidence in the literature that CD can impact growth through its ability to strengthen institutions. Improving institutional quality in developing countries to the average level of advanced economies increased annual growth in GDP per capita by 1.5 percentage points, on average, based on a 2003 IMF analysis. ${ }^{65}$

\footnotetext{
${ }^{62}$ Panel estimates confirm that IMF CD has had positive effects on growth outcomes, but it must be holistic in nature (See Appendix 5). The effect is large and significant when CD has intervened simultaneously in different areas. Additional results not shown here also suggest that larger commitments to $\mathrm{CD}$ yield greater gains to growth than small, one-off $\mathrm{CD}$ efforts.

${ }^{63}$ TA FTEs is a measure of the amount of time all IMF technical assistance mission members work in a country within a year. $1 \mathrm{FTE}$ is equal to 1 full time employment over one year.

64 These results are robust to excluding the lagged dependent variable; available upon request from the authors.

${ }^{65} \mathrm{IMF}, 2003$. The paper measures institutional quality by aggregating the six Worldwide Governance Indicators dimensions, as well as measures on property rights and on "constraint on the executive."
} 


\begin{tabular}{|c|c|}
\hline & $\begin{array}{c}\text { Dependent Variable: } \\
\text { Real GDP Per Capita } \\
\text { Growth }\end{array}$ \\
\hline \multirow[t]{2}{*}{ Total FTEs } & $0.008^{* *}$ \\
\hline & $(0.004)$ \\
\hline \multirow[t]{2}{*}{ Total FTEs $s_{t-2}$} & -0.004 \\
\hline & $(0.004)$ \\
\hline \multirow[t]{2}{*}{ Total FTEs x Anti-NIC Shock } & -0.012 \\
\hline & $(0.008)$ \\
\hline \multirow[t]{2}{*}{ Total FTEs x Anti-NIC Shock t-2 } & $0.031^{*}$ \\
\hline & $(0.018)$ \\
\hline Observations & 229 \\
\hline Adjusted R-squared & 0.899 \\
\hline Country \& Year FE & Yes \\
\hline $\begin{array}{l}\text { Full Set of Controls, including Anti-NIC Shocks \& Lagged Dependent } \\
\text { Variables }\end{array}$ & Yes \\
\hline
\end{tabular}

The results suggest that capacity development, with the consistent commitment of the authorities, can have a positive impact on AC efforts if it is part of a broader package of mutually reinforcing reforms. This includes a role for the IMF or other international organizations to act as a catalyst to improve fiscal transparency, market regulation, financial sector oversight, central banking governance, rule of law and ultimately by helping to build more inclusive and transparent institutions in member countries.

Overall, our analysis finds that there is no silver bullet to a successful AC strategy. Whether large or small, single instrument strategies - including anti-corruption laws, the creation of anti-corruption agencies, the use of technology and e-government, and support from capacity development - have had some positive impact. The sparse news on anticorruption across our sample suggests much more room for AC efforts in many cases. Even small measures can be an important step towards addressing corruption, and incorporating the AC framework as part of a broader and comprehensive package of mutually reinforcing reforms is key to reducing corruption and its associated news flow on a sustained basis. 


\section{Conclusions}

This paper constructs the first cross-country news flow measure of corruption and anticorruption, and evaluates their effects through the lens of belief formation. The measures' advantages include a higher frequency and more observed variation across time within countries; the ability to capture both corruption-related scandals and longer-term relative levels; and non-reliance on local experts. Leveraging corporate finance and macrobehavioral economics, our analysis looks at how "new" corruption-related news impacts economic agents' assessments of the nature and extent of underlying corruption and how these revised assessments change beliefs in a persistent manner that filters through to financial and real macro-outcomes.

Our findings show evidence of the macro-relevance of the news flow on corruption and anti-corruption measures. In line with our theoretical priors, NIC shocks negatively impact financial outcomes as well as longer-term real outcomes, namely growth, in a persistent manner. Our results also suggest that the macro impact of news flow on corruption is much more pronounced in EMDEs where capacity weaknesses tend to be more prevalent. With respect to anti-corruption efforts, anti-NIC shocks are insufficient to engender sustained positive outcomes on their own. However, persistent anti-NIC news flow might have a positive impact on the NIC. In addition, when coupled with capacity development efforts, anti-corruption campaigns may positively reinforce such efforts and yield larger gains to growth.

The paper also provides lessons for policymakers that are attempting to combat corruption through anti-corruption strategies. The negative effects of NIC shocks and the correlation between strong anti-NIC efforts and falling NIC levels underscore the need for policy makers to construct robust anti-corruption frameworks. When it comes to designing such programs, and as highlighted in IMF (2016) and our case studies and analysis, there is no silver bullet when it comes to addressing corruption, and anti-corruption plans must be paired with meaningful institutional reform. Our findings suggest that capacity development for EMDEs, especially fragile states, should be anchored within a longer-term framework to tackle governance and corruption vulnerabilities. Both modern technology and technical assistance, if tailored well, can provide supporting roles.

There are several avenues for future research. More empirical work is needed to causally identify the specific channels between corruption-related belief shocks and growth outcomes. Additionally, country-specific NICs and anti-NICs could be used to identify firms and sectors within countries that are particularly vulnerable to corruption-related shocks. Moreover, in this paper, we abstract from examining the underlying characteristics of corruption-related news shocks. For example, some cases may be shocking, but involve only minor financial amounts. With respect to the anti-NIC, anti-corruption campaigns may feature a number of judicial cases, a single case, or a plethora of reforms. Future research should seek to classify the different types of NIC and anti-NIC shocks to explore 
heterogeneity in their effects. Finally, data on technological improvements is improving over time; future research could focus on uncovering more empirical evidence of the role of technological breakthroughs as well as of social media on anti-corruption efforts in an increasingly digital world. 


\section{Box 3. The Role of Digitalization in Combatting Corruption}

Advances in ICT can offer a suitable alternative for anti-corruption frameworks. Anti-corruption efforts by countries have traditionally relied on law enforcement and judicial processes to discourage, identify and prosecute corrupt actors. Information and communication technology (ICT) is increasingly viewed as the new frontier for AC efforts.

\section{Recent profound transformations powered by information technology are expected to address} corruption in many ways. Digital tools can be harnessed to modernize public sector processes and improve service delivery. Examples include e-filing of taxes, and e-governance. ${ }^{1}$ While the relationship between corruption and digitalization has not been studied in detail, several papers study the channels through which digitalization could prevent and reduce corruption exists. These include:

- Enhancing accountability in the public sector (Aucoin et al., 2000; MOJ, Estonia, 2006-2014; Pina et al., $2007)^{2}$

- Increasing transparency in dealing with the public sector (Bailur and Gigler, 2014)

- Removing the role of the "middleman" of a public officer (World Bank, 2016; Dupuy and Serrat, 2014; Zinnbauer, 2012)

- Enhancing faster detection of corruption through open data techniques (Srivastava, 2016)

- Improving public service delivery (Giannakopoulos et al., 2009)

- Enhancing financial access and inclusion (ADB, 2016)

ICT has the potential to positively impact various domains of the public sector: taxation, procurement, human resource management, data management, among others. ${ }^{3}$ Successful examples include Estonia in applying e-governance to all frontiers of public finance and public service domains; Tanzania as well as Kenya with its money-transfer system M-Pesa (that originated a revolution in tax policy and administration). It included a web-enabled application for tax administration (the iTax System) and the possibility for taxpayers to pay taxes and access their tax information through their mobile phones (the M-service platform). Others include: Bangladesh with its programs to digitalize land services and the its introduction of electronic and mobile ticketing in the Bangladesh Railway; India with its many e-governance projects including the corruption reporting platform, increased citizen's participation in the "Smartcards" and "Aadhaar" programs, Bhoomi project on open data, among others; Indonesia and South Korea with improved procurement systems; and Russia with digitalization of legal and law enforcement systems.

${ }^{1}$ Oxford Dictionaries (2016) define digitalization as: "The conversion of text, pictures, or sound into a digital form that can be processed by a computer", while the academic concept is much broader. Khan (2016) describes three different concepts which are closely linked: digitization, digitalization, and digital transformation. And there are other definitions such as e-governance, Information and Communication Technologies (ICTs), automation and artificial intelligence. In this box, we treat all terms to serve the same purpose of affecting corruption and thus having the same conceptual meaning.

${ }^{2}$ To measure the accountability of Estonia, the Worldwide Governance Indicator for voice and accountability was used. Generally, accountability refers to the ability of citizens (by facilitating audits, preventive checks, and ongoing investigation of corrupt acts already detected) to track activities and monitor and control government employees (Shim \& Eom 2008: 303).

${ }^{3}$ See Araki and Claus (2014), Githinji, et al. (2014) and Chatama (2013) on taxation; USAID (2016) on procurement; Chêne (2015) and Tursunbayeva et al. (2015) on human resource management; and Anderson (2009) on public sector data management and public-sector service delivery. 


\section{Box 3. The Role of Digitalization in Combatting Corruption (concluded)}

\section{However, digitalization should not be viewed as a panacea for corruption or a perfect substitute for} fundamental policy and institutional problems. ${ }^{4}$ Evidence from Estonia has shown that even with increased transparency and improved public service delivery, accountability has remained constant; and in India's Aadhaar program case, may have gotten worse. Finally, to limit the negative social and economic impact of technological change, it is critical to (i) ensure equal public access to technology and active citizen engagement; (ii) increase citizens' technological literacy and social and technology readiness (Bertot et al., 2010); (iii) enhance citizens' broader participation in e-government services and (iv) improve legal frameworks, organizational processes, leadership and campaign strategies (Davies and Fumega, 2014).

We analyze the technological impact on the NIC. We precisely document the dates of technological initiatives, their adoption, implementation and operational stages for five countries (Bangladesh 2010, India 2001; 2011, Indonesia 2012, Korea 1997) and analyze their respective impact on the NIC. As can be seen from the charts, after an initial drop in the NIC it rises again after a few periods. ${ }^{5}$ Though uncertainty with respect to other unexplained factors exists, it is possible that the rise in the NIC reflects the tendency of corruption to find its way around anti-corruption efforts, even technological ones. One could also argue that in the short run in most technology-adopting countries the necessary conditions are not yet fully satisfiedaccess to technology, technological literacy, social and technology readiness, citizens' broader participation in e-government services and the existence of legal frameworks, organizational processes, and leadership and campaign strategies. The corrupt agents could use holes in these areas to continue corrupt behavior, explaining why the drop in NIC is not sustainable in the longer-run. More generally however, we observe a positive relationship between a "government usage" sub-index of the networked readiness indicator (NRI) and the NIC. ${ }^{6}$ Once technological advances in providing government services are rooted in and necessary conditions satisfied, the reflection in the NIC becomes more visible and sustainable.
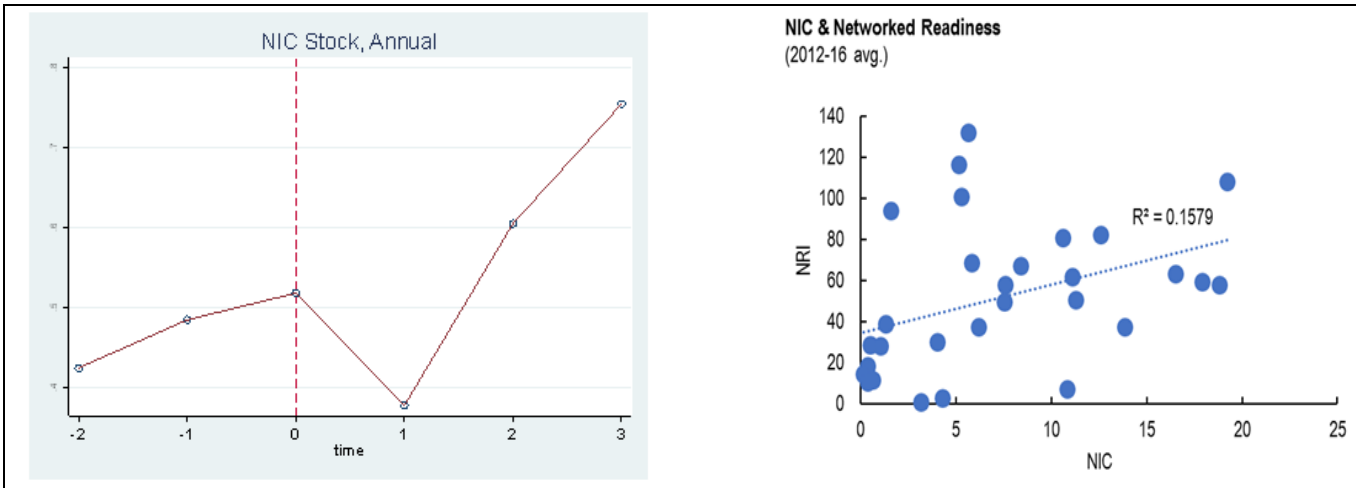

${ }^{4}$ Gupta, Sanjeev, Michael Keen, Alpa Shah and Geneviève Verdier, Forthcoming in 2017, Digital Revolutions in Public Finance International Monetary Fund (supported by the Bill and Melinda Gates Foundation).

${ }^{5}$ The pre/post $\mathrm{t}$-test statistic is significant (t-stat: 2.186$)$.

${ }^{6}$ The "government usage" sub-index of the NRI is defined as a combination of three variables: government efforts in carrying out ICT policies for competitiveness and wellbeing, efforts in implementing ICT development strategies, and the number of government services provided online. A lower NRI score implies more readiness. 


\section{Box 4. IMF's Capacity Development Work and Anti-Corruption Efforts}

The IMF's capacity development (CD) work in the Philippines, Indonesia and Nepal provides important policy lessons on the role $C D$ can play in contributing to anti-corruption efforts.

\section{Philippines:}

In 2010, the Philippines elected President Aquino on an anti-corruption platform "where there is no corruption, there will be no poverty". His government initiated a large amount of reform programs, some of them supported by TA from the IMF's Fiscal Affair (FAD) department (in particular, a 5-year Revenue Administration reform program and a Public Financial Management (PFM) program). In addition, the IMF's Monetary and Capital Markets (MCM) department provided a fair amount of TA on banking supervision. The Revenue Administration reform program is particularly relevant because one of its main objective was, as stated by the authorities, to tackle public sector corruption by reducing discretion of revenue collection officers and improving the predictability impartiality of revenue laws and regulation. To do so, priorities were set, consisting of institutionalizing new procedures in the arrears management and VAT audits pilots, enhancing taxpayer compliance and integrating new IT systems. Several assessments (Fiscal Transparency Evaluation (FTE), Tax Administration Diagnostic Assessment Tool (TADAT)) conducted around the end of the program noted improvements in tax administration efforts (increase tax base, collection performance), VAT audit, arrears management and strengthening of cash flow management and fiscal framework. In 2016, 5 years after the reform programs were initiated, tax revenue had increased back to its pre-GFC level, and the C-efficiency ratio was improved. The fiscal TA had a positive impact on fiscal outcome, since the reforms that were realized aimed at enhancing collection performance. However, other projects originally planned to improve fiscal governance and transparency had yet to be implemented. Overall, the reform programs seem to have had little direct effect on the perception of corruption and institutional strength based on the selected measures. The NIC and anti-NIC measures also show little improvement over time.
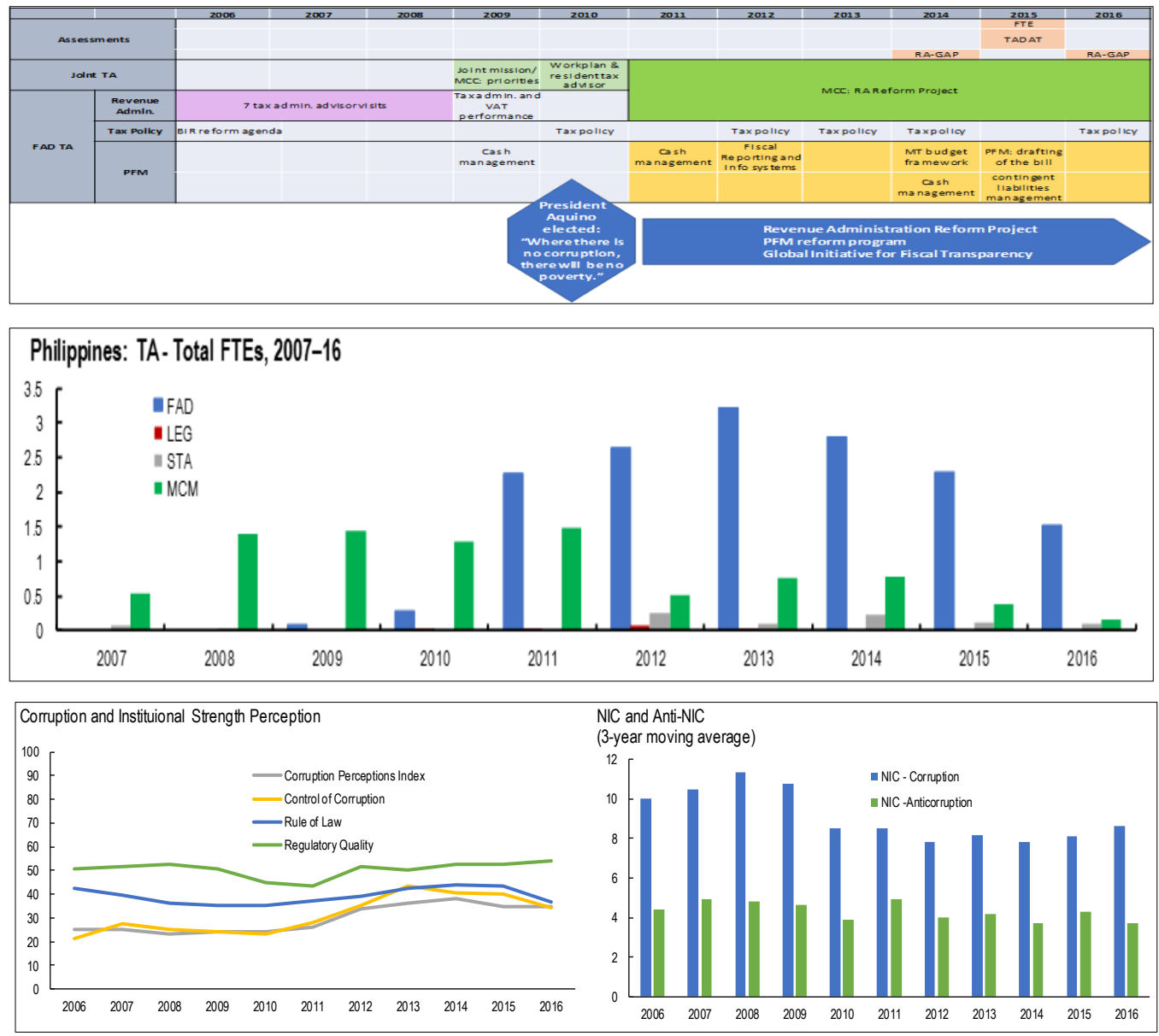


\section{Box 4. IMF's Capacity Development Work and Anti-Corruption Efforts (concluded)}

\section{Indonesia}

Indonesia also received a large amount of TA from the IMF's FAD (revenue administration and PFM) and MCM (banking supervision). Fiscal reforms had ambitious objectives: (i) improving the legal framework for tax administration (seeking appropriate balance of power for tax agencies, enforce tax law while protecting taxpayers), (ii) enhancing VAT compliance, improving governance: (setting a code of conduct for tax officers, special compensation package, and a hotline to receive complaints), (iii) implementing taxpayer services IT systems and; (iv) improving audit function. In addition, Indonesia is the country in the region that was provided the most amount of TA from the IMF's Legal department (LEG) in the last 10 years. Between 2008 and 2011, Indonesia, with the help of the IMF, designed and implemented the AML/CFT framework as well as a National Legal Reforms program. Over the 2010-16 period, and despite a large amount of fiscal TA (from the IMF and other organizations), non-oil tax revenue continued to decline. However, unlike in the case of the Philippines, measures of institutional strength and corruption perception improved significantly and the NIC measure declined over the period.

\section{IMF Fiscal and Legal TA}

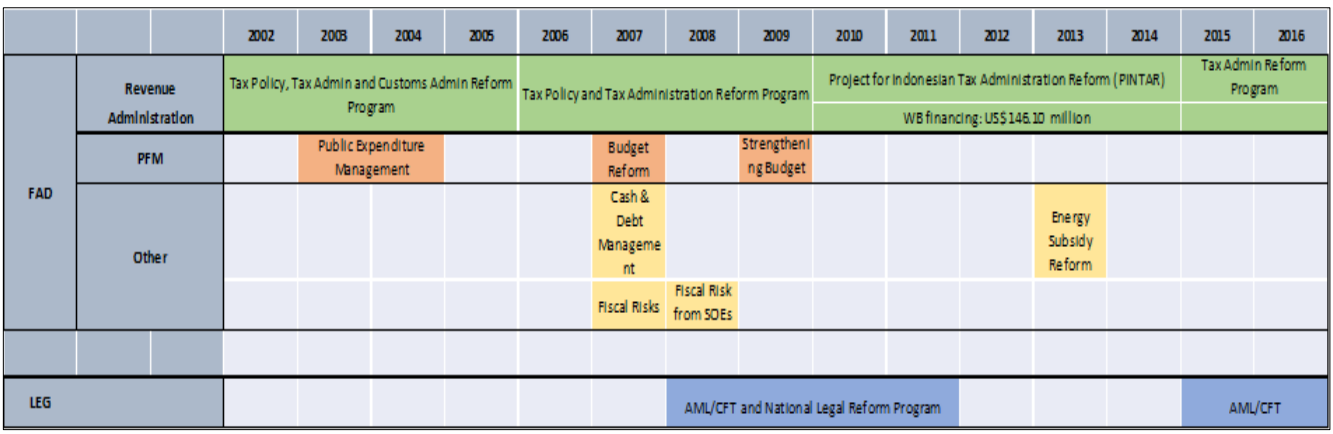
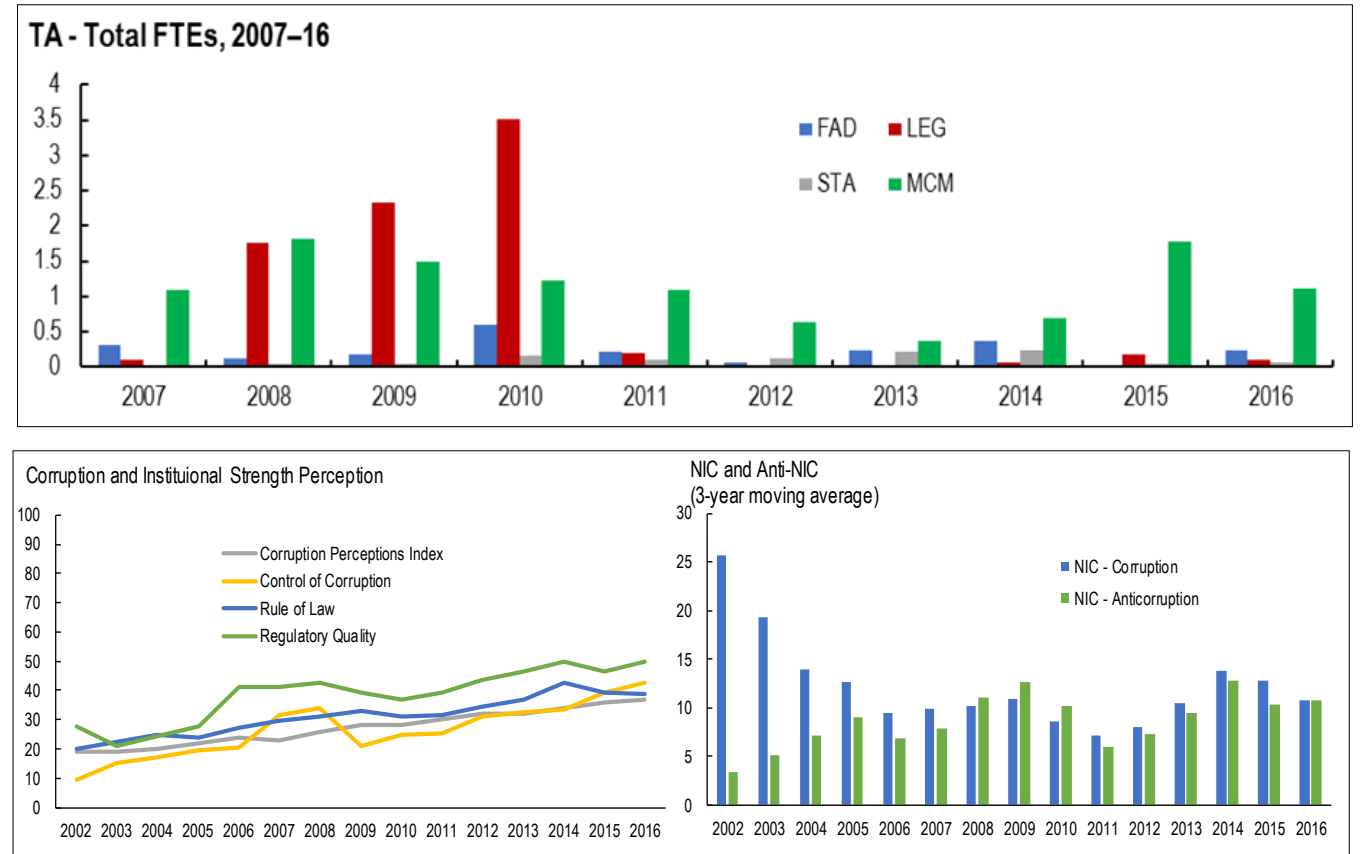

\section{Nepal}

The case of Nepal is very similar to the one of the Philippines. A large amount of FAD TA in tax and customs administration reforms have helped improved the tax revenue from 8.9 percent of GDP in 2006 to 18.9 in 2016 . The IMF also provided TA for implementing the AML/CFT framework. However, over the period, measures of institutional strength have remained low and perception of corruption was unchanged at a high level. 


\section{Appendix I. Search Algorithm Dictionaries}

Baseline Corruption Algorithm

\begin{tabular}{|c|c|c|c|c|}
\hline Corruption Term: & Within 8 words of: & Within 8 words of: & $\begin{array}{l}\text { Not mentioning anti- } \\
\text { corruption } \\
\text { campaigns: }\end{array}$ & Limited to: \\
\hline $\begin{array}{c}\text { corrupt* } \\
\text { kleptoc* } \\
\text { nepotism } \\
\text { favoritism } \\
\text { rent-seeking } \\
\text { bribe* } \\
\text { graft } \\
\text { extortion } \\
\text { kickback* } \\
\text { grease payment* } \\
\text { facilitation payment* } \\
\text { facilitation fee* } \\
\text { illegal pact } \\
\text { solicitation } \\
\text { double-dealing } \\
\text { siphon* near2 funds } \\
\text { crony* } \\
\text { scam* }\end{array}$ & $\begin{array}{l}\text { [COUNTRY NAME } \\
\text { or DEMONYM] }\end{array}$ & $\begin{array}{c}\text { government } \\
\text { regime } \\
\text { authorities } \\
\text { public sector } \\
\text { bureaucra* } \\
\text { agenc* } \\
\text { ministr* } \\
\text { public off* } \\
\text { administrat* } \\
\text { civil service } \\
\text { bureau or committee } \\
\text { cabinet } \\
\text { president } \\
\text { minister* } \\
\text { military } \\
\text { state-owned } \\
\text { SOE } \\
\text { parliament* } \\
\text { legislature } \\
\text { assembly } \\
\text { central bank } \\
\text { reserve bank }\end{array}$ & $\begin{array}{c}\text { anti-corrupt* } \\
\text { anti-graft } \\
\text { lower or decreas* or } \\
\text { improv* or crack* } \\
\text { down or crackdown or } \\
\text { control of curb* or } \\
\text { fight* or battl* or war } \\
\text { or combat* or tackl* } \\
\text { or root out or end to or } \\
\text { counter* } \\
\text { near2 } \\
\text { corrupt* or graft }\end{array}$ & $\begin{array}{l}\text { Articles over } 99 \\
\text { words (removes } \\
\text { ticker articles) } \\
\text { Major news } \\
\text { sources } \\
\text { Articles about the } \\
\text { country (as } \\
\text { characterized by } \\
\text { news aggregator) }\end{array}$ \\
\hline
\end{tabular}

Core Corruption Algorithm

\begin{tabular}{|c|c|c|c|c|}
\hline Corruption Term: & Within 8 words of: & Within 8 words of: & $\begin{array}{c}\text { Not mentioning anti- } \\
\text { corruption } \\
\text { campaigns: }\end{array}$ & Limited to: \\
\hline $\begin{array}{l}\text { corrupt* } \\
\text { kleptoc* } \\
\text { nepotism } \\
\text { graft }\end{array}$ & $\begin{array}{l}\text { [COUNTRY NAME } \\
\text { or DEMONYM] }\end{array}$ & $\begin{array}{c}\text { government } \\
\text { regime } \\
\text { authorities } \\
\text { public sector } \\
\text { bureaucra* } \\
\text { agenc* } \\
\text { ministr* } \\
\text { public off* } \\
\text { administrat* } \\
\text { civil service } \\
\text { bureau or committee } \\
\text { cabinet } \\
\text { president } \\
\text { minister* } \\
\text { military } \\
\text { state-owned } \\
\text { SOE } \\
\text { parliament* } \\
\text { legislature } \\
\text { assembly } \\
\text { central bank } \\
\text { reserve bank }\end{array}$ & $\begin{array}{c}\text { anti-corrupt* } \\
\text { anti-graft } \\
\text { lower or decreas* or } \\
\text { improv* or crack* } \\
\text { down or crackdown or } \\
\text { control of curb* or } \\
\text { fight* or battl* or war } \\
\text { or combat* or tackl* } \\
\text { or root out or end to or } \\
\text { counter* } \\
\text { near2 } \\
\text { corrupt* or graft }\end{array}$ & $\begin{array}{l}\text { Articles over } 99 \\
\text { words (removes } \\
\text { ticker articles) } \\
\text { Major news } \\
\text { sources } \\
\text { Articles about the } \\
\text { country (as } \\
\text { characterized by } \\
\text { news aggregator) }\end{array}$ \\
\hline
\end{tabular}


Anti-Corruption Algorithm

\begin{tabular}{|c|c|c|c|}
\hline Anti-corruption: & Within 8 words of: & Within 8 words of: & Limited to: \\
\hline $\begin{array}{c}\text { anti-corrupt* } \\
\text { anti-graft } \\
\text { lower or decreas* or } \\
\text { improv* or crack* down or } \\
\text { crackdown or control of } \\
\text { curb* or fight* or battl* or } \\
\text { war or combat* or tackl* or } \\
\text { root out or end to or } \\
\text { counter* } \\
\text { near2 } \\
\text { corrupt* or graft }\end{array}$ & $\begin{array}{c}\text { [COUNTRY NAME or } \\
\text { DEMONYM] }\end{array}$ & $\begin{array}{c}\text { government } \\
\text { regime } \\
\text { authorities } \\
\text { public sector } \\
\text { bureaucra* } \\
\text { agenc* } \\
\text { ministr* } \\
\text { public off* } \\
\text { administrat* } \\
\text { civil service } \\
\text { bureau or committee } \\
\text { cabinet } \\
\text { president } \\
\text { minister* } \\
\text { military } \\
\text { state-owned } \\
\text { SOE } \\
\text { parliament* } \\
\text { legislature } \\
\text { assembly } \\
\text { central bank } \\
\text { reserve bank }\end{array}$ & $\begin{array}{l}\text { Articles over } 99 \text { words } \\
\text { (removes ticker articles) } \\
\text { Major news sources } \\
\text { Articles about the country } \\
\text { (as characterized by news } \\
\text { aggregator) }\end{array}$ \\
\hline
\end{tabular}

+ Lobbying Algorithm (Bolded Terms)

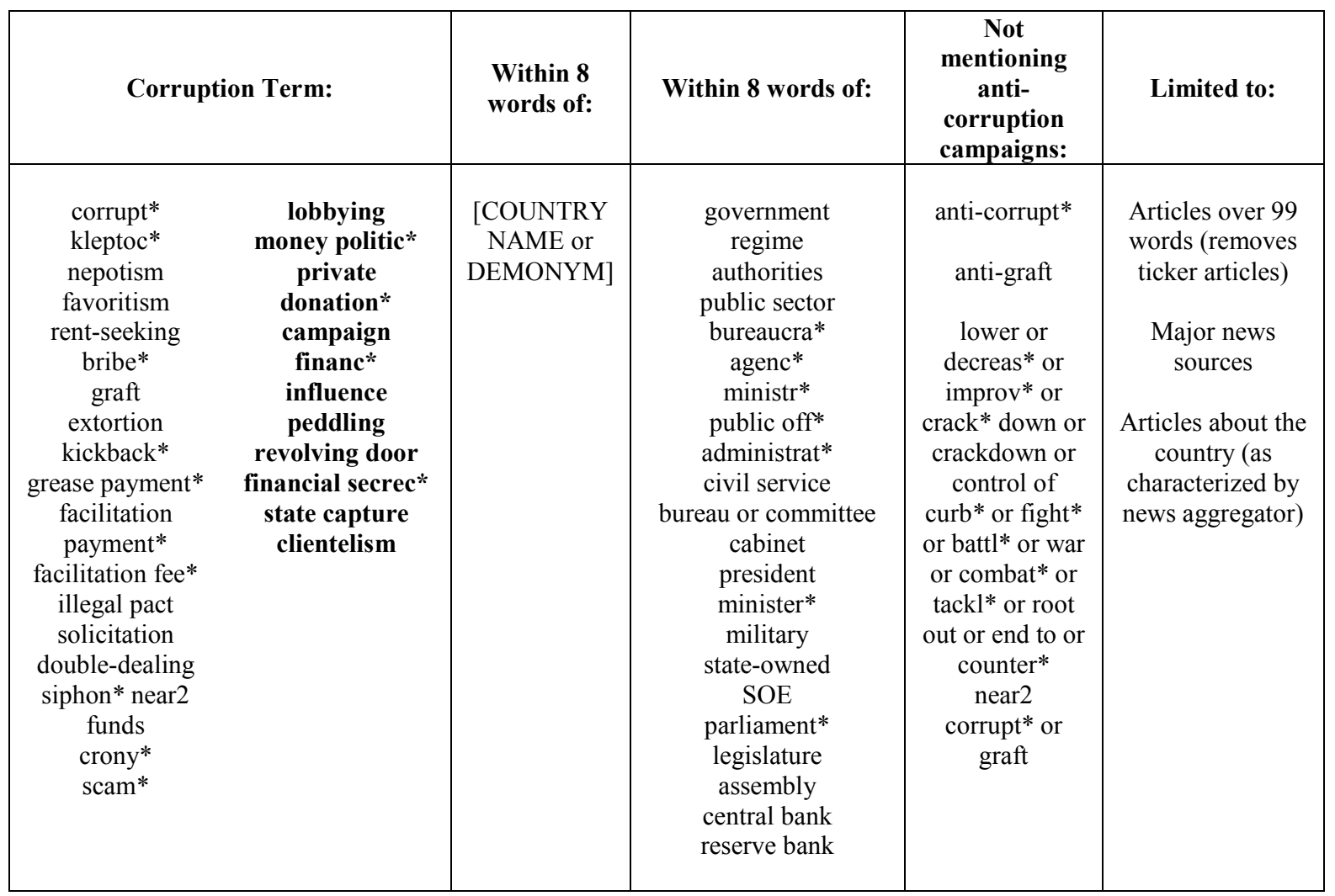




\section{Appendix II. Construction of the News Flow Measure of Corruption}

1. Country-specific search algorithms that count the number of articles that meet a 5-part metric:

- mention of the country within 8 words of corruption-related term

- mention of government-related term within 8 words

- no mention of anti-corruption efforts

- a length of at least 99 words

- limited to major newspapers and no own-country sources

2. Indexation:

- Normalization by total news coverage of the country over time

- Index from $[0,100]$, with higher levels implying more corruption news flow

3. Extensions: Anti-corruption, lobbying and core indices

4. Algorithms are run on Factiva:

- $\quad 36,000$ sources in 28 languages

- The Wall Street Journal, The New York Times, Washington Post, The Financial Times, The Globe and Mail, the Guardian, etc.

- Over 450 continuously updated newswires / 700 wires (e.g., Associated Press and Reuters)

- Website Publications: e.g., The NYT Online Edition

- $665+$ million articles in English 


\section{Appendix III. NIC Robustness Checks}

For the human audits, with each article we answered the following questions for the corruption human audit:

1. Is the reference about the intended country?

2. Is the reference about corruption ("public abuse for private gain")?

3. If the article is about corruption, is the reference about an increase or decrease in corruption, or is it ambiguous?

4. Is this a current (within year) episode of corruption?

5. What is the source of corruption?

6. Are we picking up petty or grand corruption?

7. Is it a perception of corruption (e.g., opinions of possible corruption) or actual/real corruption?

8. Is the reference associated with a political purge?

For the anti-corruption human audit, we answered the following questions:

1. Is the reference about the intended country?

2. Is the reference about anti-corruption efforts?

3 . Is this a current (within year) episode of anti-corruption?

4. Is it targeted at petty or grand corruption?

5. Is it perception of anti-corruption or actual anti-corruption efforts?

6. Is the reference associated with a political purge?

7. Is this about a specific case (e.g., a trial) or about general anti-corruption efforts?

\begin{tabular}{|lc|}
\hline \multicolumn{2}{|c|}{ Table 1. Anti-NIC Search Algorithm Results Audit } \\
\hline Correct Country? & 92.4 \\
About Anti-Corruption? & 82.0 \\
\multicolumn{1}{|c|}{ Of correct country \& } & about anti-corruption... \\
Actual (vs. Perceptions)? & 87.9 \\
Specific (vs. General Efforts)? & 49.3 \\
Related to a Political Purge? & 3.1 \\
\hline $\begin{array}{l}\text { Note: In percent. Based on a random sampling of } 290 \text { articles; } 95 \% \text { confidence } \\
\text { level with }+/-5 \text { confidence interval. }\end{array}$ \\
\hline
\end{tabular}




\begin{tabular}{|c|c|c|c|c|c|c|}
\hline \multicolumn{7}{|c|}{ Table 2. Pearson's Correlation Coefficients } \\
\hline & NIC & $\begin{array}{l}\text { Anti- } \\
\text { NIC }\end{array}$ & $\begin{array}{l}\text { Lobbying } \\
\text { NIC }\end{array}$ & $\begin{array}{l}\text { Core } \\
\text { NIC }\end{array}$ & $\begin{array}{c}\text { Civil } \\
\text { Liberties } \\
\text { Adjusted } \\
\text { NIC }\end{array}$ & $\begin{array}{l}\text { Press Freedom } \\
\text { Adjusted NIC }\end{array}$ \\
\hline NIC & 1 & & & & & \\
\hline Anti-NIC & $0.325^{*}$ & 1 & & & & \\
\hline Lobbying NIC & $0.996 *$ & $0.313^{*}$ & 1 & & & \\
\hline Core NIC & $0.973 *$ & $0.348^{*}$ & $0.969^{*}$ & 1 & & \\
\hline Civil Liberties Adjusted NIC & $0.888^{*}$ & $0.373^{*}$ & $0.884^{*}$ & $0.886^{*}$ & 1 & \\
\hline Press Freedom Adjusted NIC & $0.951 *$ & $0.402 *$ & $0.947 *$ & $0.936^{*}$ & $0.965^{*}$ & 1 \\
\hline
\end{tabular}

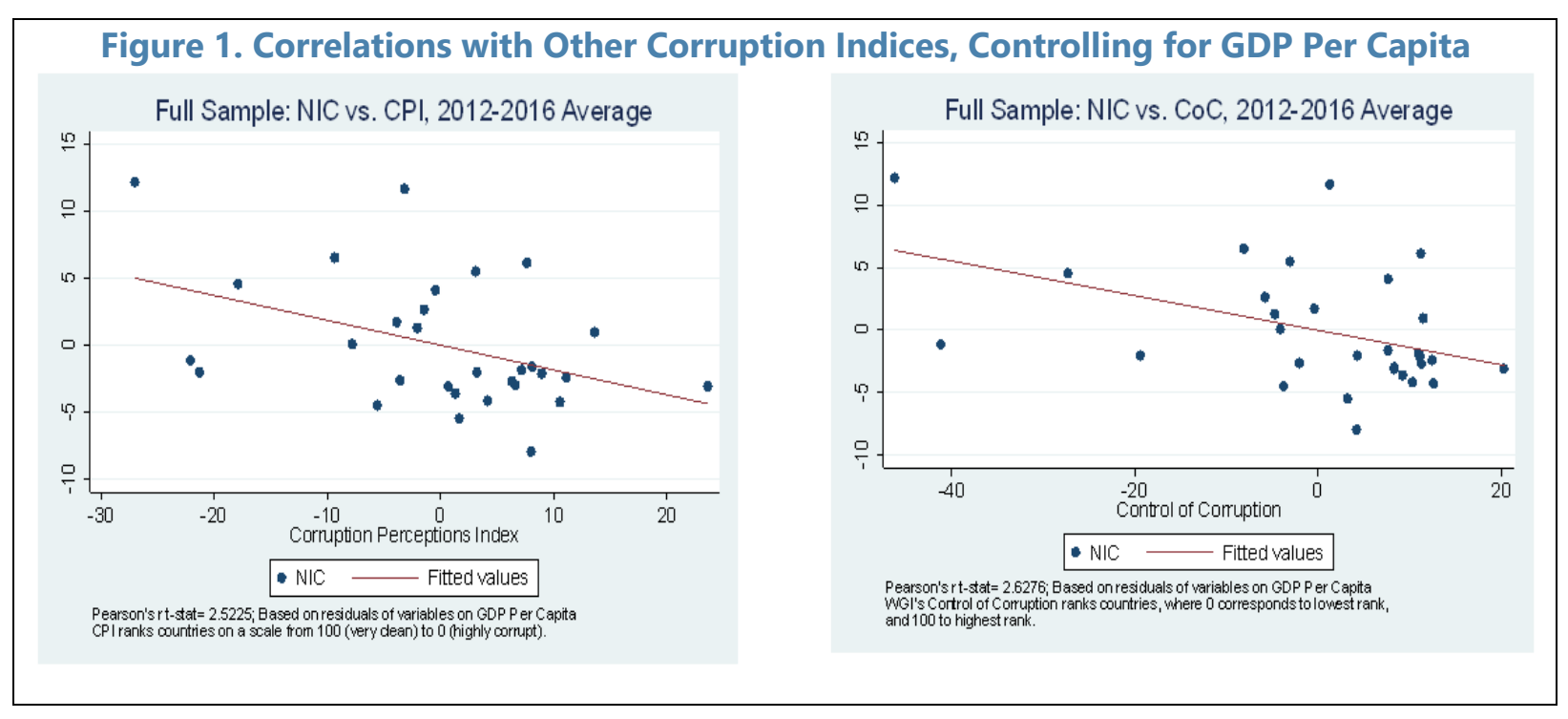




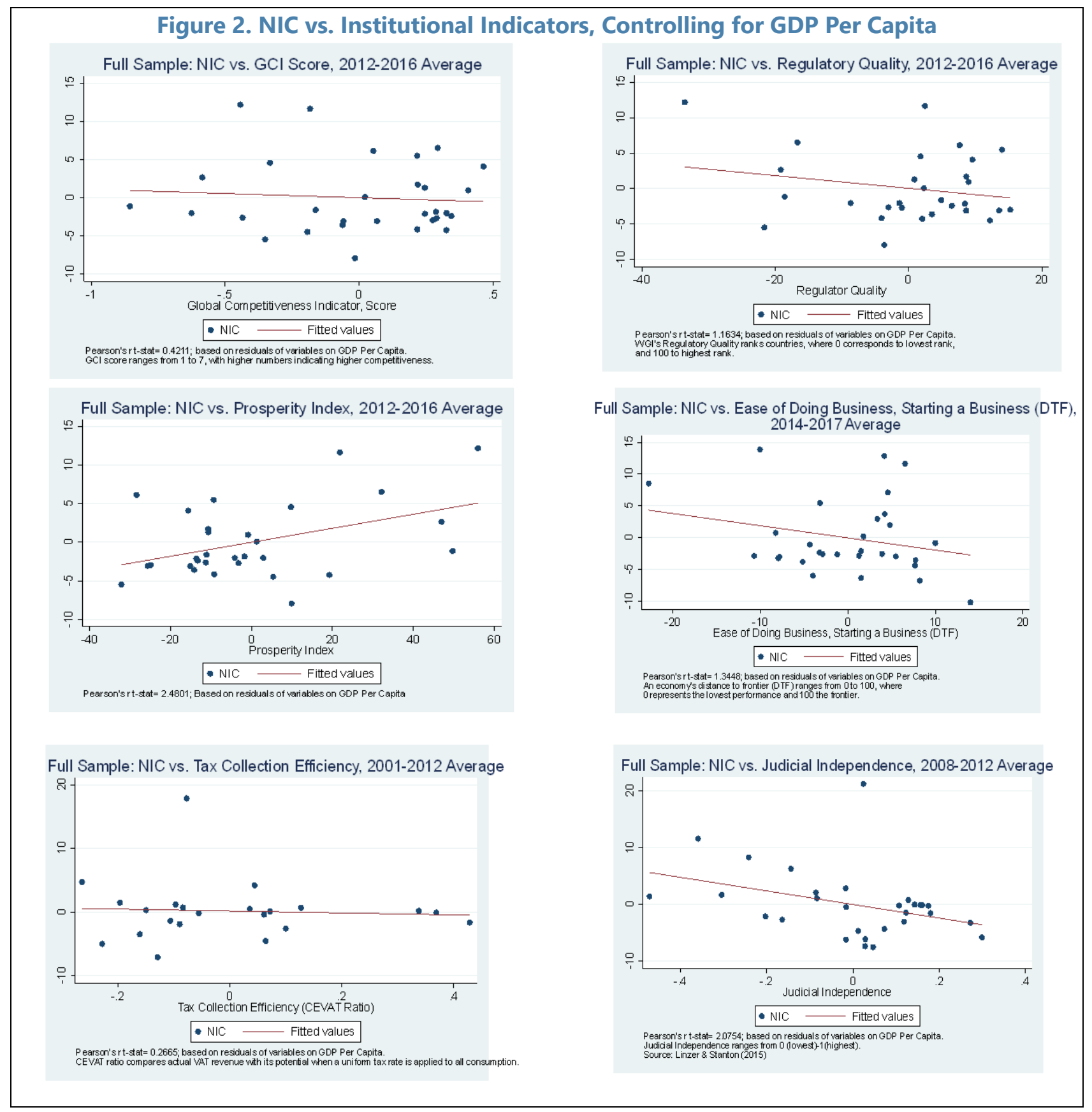

CInternational Monetary Fund. Not for Redistribution 


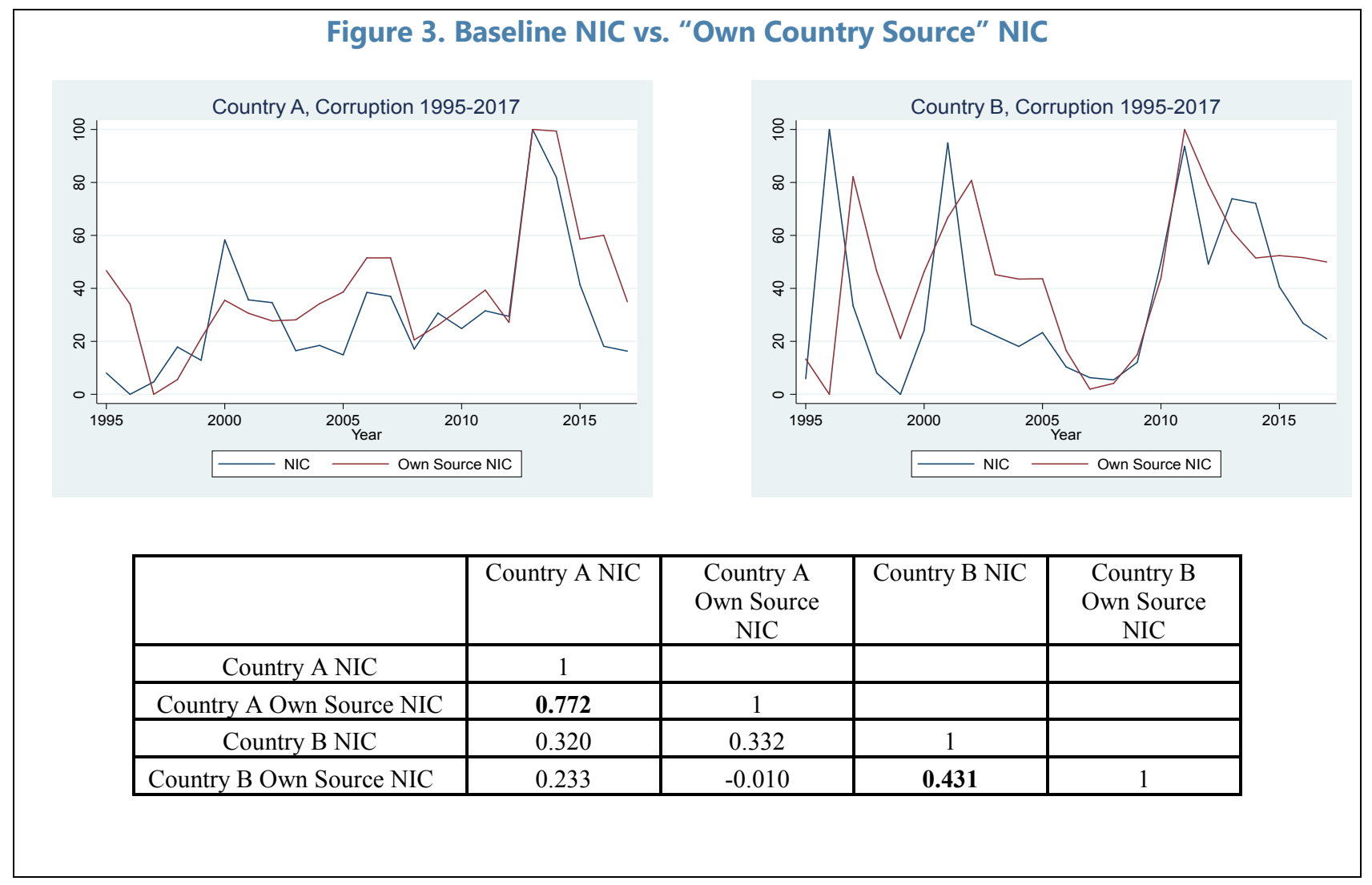

\begin{tabular}{|c|c|c|}
\hline Null Hypothesis & Chi-Squared & Prob $>$ Chi-Squared \\
\hline CPI does not Granger cause NIC & $5.135^{* *}$ & 0.023 \\
\hline CoC does not Granger cause NIC & $2.713^{*}$ & 0.100 \\
\hline NIC does not Granger cause CPI & 0.009 & 0.924 \\
\hline NIC does not Granger cause CoC & 0.001 & 0.977 \\
\hline
\end{tabular}

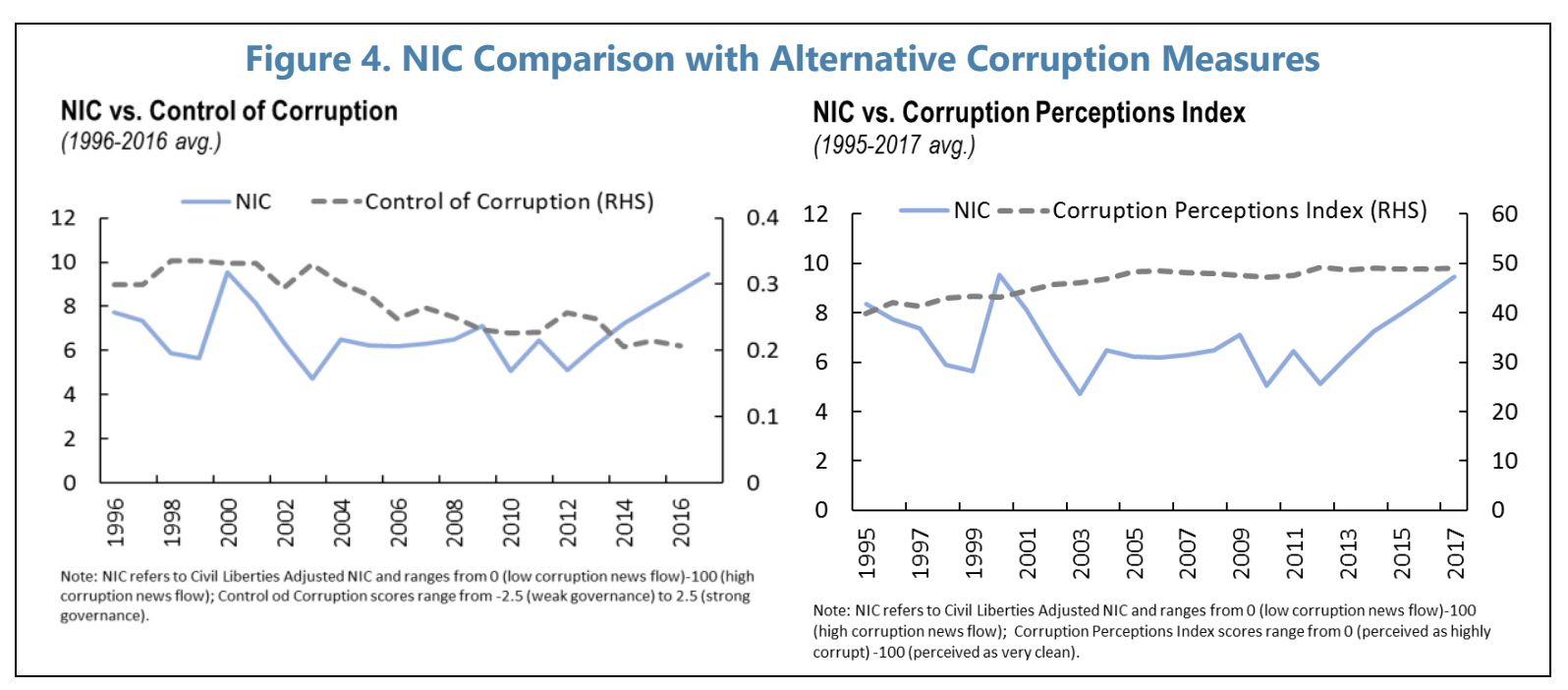

CInternational Monetary Fund. Not for Redistribution 


\section{Appendix IV. Stylized Facts: NIC and Anti-NIC}

\begin{tabular}{|c|c|c|c|c|c|}
\hline & \multicolumn{5}{|c|}{ Summary Statistics } \\
\hline & & Overall & AE's & EM's & LIDC's \\
\hline \multirow{5}{*}{ NIC } & Mean & 7.9 & 3.0 & 10.0 & 14.5 \\
\hline & Median & 7.7 & 1.9 & 9.1 & 10.2 \\
\hline & Std. Deviation & 5.8 & 3.0 & 4.3 & 9.0 \\
\hline & Maximum & 24.8 & 10.2 & 18.1 & 24.8 \\
\hline & Minimum & 0.6 & 0.6 & 3.4 & 8.4 \\
\hline \multirow{5}{*}{$\begin{array}{l}\text { Lobbying } \\
\text { NIC }\end{array}$} & Mean & 8.7 & 3.7 & 10.9 & 14.9 \\
\hline & Median & 8.6 & 2.6 & 10.0 & 11.0 \\
\hline & Std. Deviation & 5.9 & 3.0 & 4.4 & 8.9 \\
\hline & Maximum & 25.0 & 11.0 & 19.2 & 25.0 \\
\hline & Minimum & 1.0 & 1.0 & 4.0 & 8.7 \\
\hline \multirow{5}{*}{ Core NIC } & Mean & 7.1 & 2.2 & 9.2 & 13.8 \\
\hline & Median & 6.5 & 1.4 & 8.5 & 9.9 \\
\hline & Std. Deviation & 5.6 & 2.2 & 4.0 & 8.6 \\
\hline & Maximum & 23.7 & 7.0 & 16.9 & 23.7 \\
\hline & Minimum & 0.3 & 0.3 & 3.0 & 7.8 \\
\hline \multirow{5}{*}{$\begin{array}{l}\text { Press Freedom } \\
\text { Adjusted NIC }\end{array}$} & Mean & 8.0 & 1.5 & 10.3 & 18.9 \\
\hline & Median & 6.7 & 0.9 & 10.4 & 15.6 \\
\hline & Std. Deviation & 7.0 & 1.5 & 4.3 & 10.5 \\
\hline & Maximum & 30.6 & 4.6 & 17.0 & 30.6 \\
\hline & Minimum & 0.1 & 0.1 & 4.4 & 10.5 \\
\hline \multirow{5}{*}{$\begin{array}{l}\text { Civil Liberties } \\
\text { Adjusted NIC }\end{array}$} & Mean & 6.9 & 1.3 & 8.7 & 18.0 \\
\hline & Median & 5.5 & 0.7 & 9.5 & 14.5 \\
\hline & Std. Deviation & 6.6 & 1.4 & 3.6 & 12.0 \\
\hline & Maximum & 31.3 & 4.9 & 14.4 & 31.3 \\
\hline & Minimum & 0.1 & 0.1 & 3.3 & 8.1 \\
\hline \multirow{5}{*}{$\begin{array}{c}\text { Anti-Corruption } \\
\text { NIC }\end{array}$} & Mean & 2.6 & 0.7 & 3.1 & 6.7 \\
\hline & Median & 1.6 & 0.5 & 2.0 & 8.2 \\
\hline & Std. Deviation & 2.5 & 0.8 & 2.2 & 2.7 \\
\hline & Maximum & 8.4 & 3.1 & 7.8 & 8.4 \\
\hline & Minimum & 0.1 & 0.1 & 0.9 & 3.5 \\
\hline
\end{tabular}


Figure 1. NIC Comparisons with Alternative Corruption Measures, by income level

NIC vs. Control of Corruption - AE's

(1996-2016 avg.)

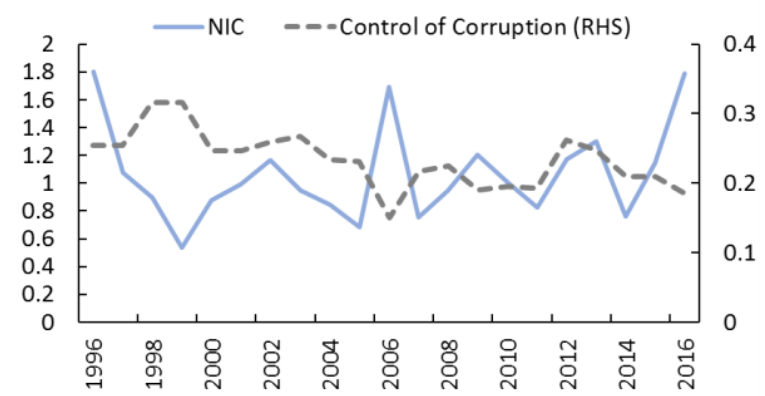

Note: NIC refers to Civil Liberties Adjusted NIC and ranges from 0 (low corruption news flow)-100 (high corruption news flow); Control od Corruption scores range from - 2.5 (weak governance) to 2.5 (strong
governance).

NIC vs. Control of Corruption - EM's

(1996-2016 avg.)

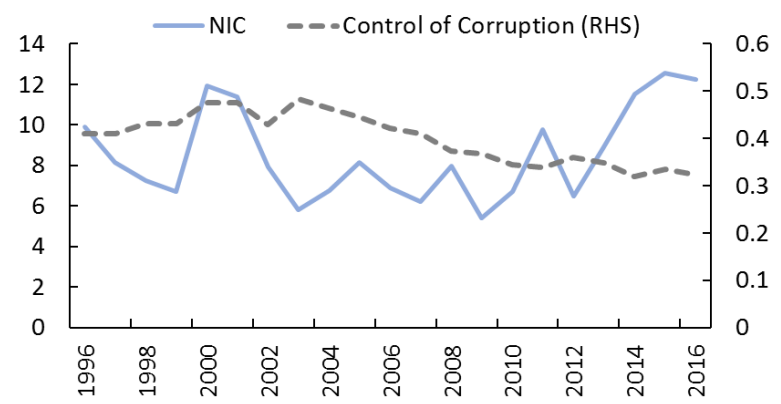

Note: NIC refers to Civil Liberties Adjusted NIC and ranges from 0 (low corruption news flow)-100 (high corruption news flow); Control od Corruption scores range from - 2.5 (weak governance) to 2.5 (strong governance).

\section{NIC vs. Control of Corruption - LIDC's}

(1996-2016 avg.)

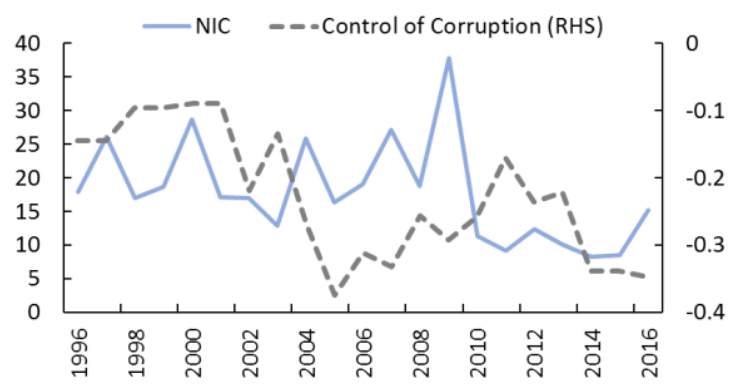

Note: NIC refers to Civil Liberties Adjusted NIC and ranges from 0 (low corruption news flow)-100 (high corruption news flow); Control od Corruption scores range from - 2.5 (weak governance) to 2.5 (strong governance).

\section{NIC vs. Corruption Perceptions Index - AE's} (1995-2017 avg.)

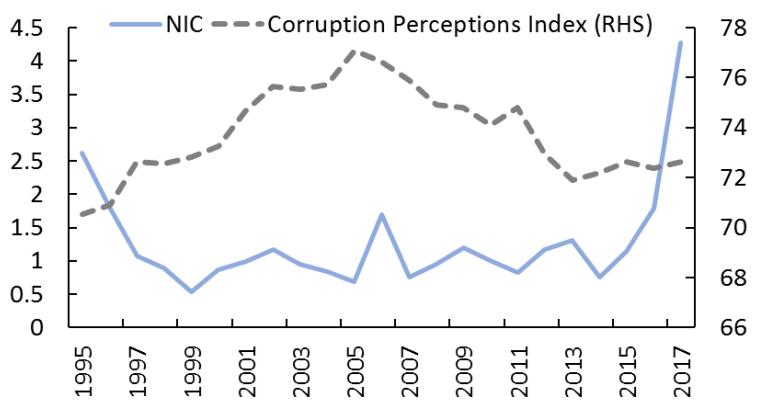

Note: NIC refers to Civil Liberties Adjusted NIC and ranges from 0 (low corruption news flow)-100 (high corruption news flow); Corruption Perceptions Index scores range from 0 (perceived as highly corrupt) -100 (perceived as very clean).

NIC vs. Corruption Perceptions Index - EM's (1995-2017 avg.)

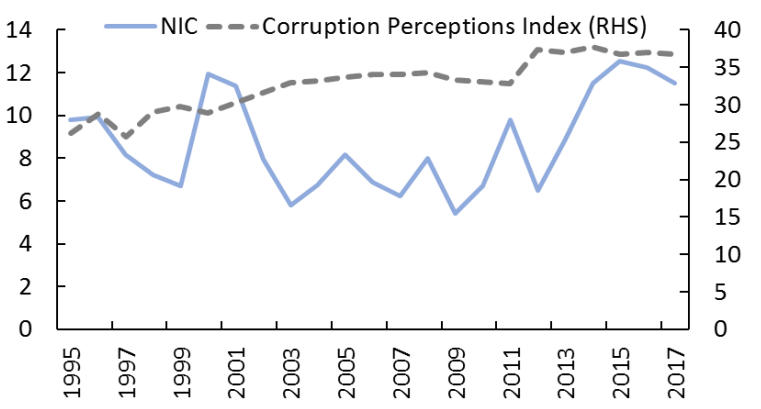

Note: NIC refers to Civil Liberties Adjusted NIC and ranges from 0 (low corruption news flow)-100 (high corruption news flow); Corruption Perceptions Index scores range from 0 (perceived as highly corrupt) - 100 (perceived as very clean

\section{NIC vs. Corruption Perceptions Index - LIDC's} (1995-2017 avg.)

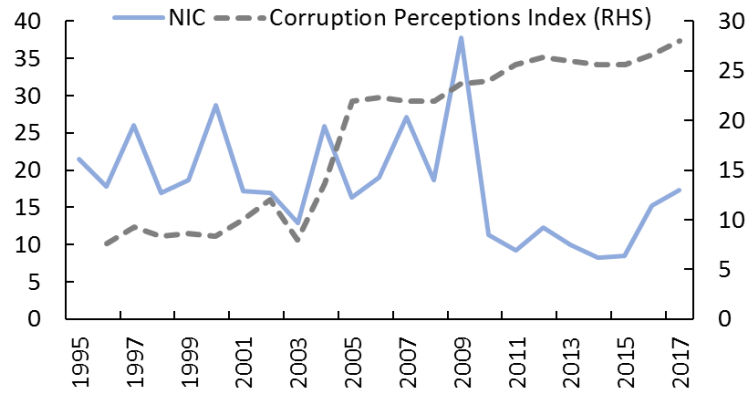

Note: NIC refers to Civil Liberties Adjusted NIC and ranges from 0 (low corruption news flow)-100 (high corruption news flow); Corruption Perceptions Index scores range from 0 (perceived as highly corrupt) -100 (perceived as very clean). 


\section{Appendix V. Additional Panels Estimations Results}

\begin{tabular}{|c|c|c|c|c|}
\hline \multicolumn{5}{|c|}{ Table 1. Full Sample } \\
\hline $\begin{array}{l}\text { Full Results with Lagged } \\
\text { Dependent Variables }\end{array}$ & $\begin{array}{c}\text { (1) } \\
\text { Real GDP Per } \\
\text { Capita Growth }\end{array}$ & $\begin{array}{c}\text { (2) } \\
\text { Revenues/ } \\
\text { GDP }\end{array}$ & $\begin{array}{c}\text { (3) } \\
\text { Portfolio } \\
\text { Investment/ } \\
\text { GDP }\end{array}$ & $\begin{array}{l}\text { (4) } \\
\text { Direct Investment/ } \\
\text { GDP }\end{array}$ \\
\hline NIC Shock & $\begin{array}{l}-0.0187^{* *} \\
(0.00740)\end{array}$ & $\begin{array}{l}-0.00308 \\
(0.00408)\end{array}$ & $\begin{array}{l}0.0337 \\
(0.0798)\end{array}$ & $\begin{array}{l}-0.0318 \\
(0.0665)\end{array}$ \\
\hline NIC Shockt-1 & $\begin{array}{l}-0.0110^{*} \\
(0.00541)\end{array}$ & $\begin{array}{c}0.00107 \\
(0.00184)\end{array}$ & $\begin{array}{l}-0.0629 \\
(0.0744)\end{array}$ & $\begin{array}{l}-0.0235 \\
(0.0375)\end{array}$ \\
\hline Anti-NIC Stock & $\begin{array}{l}-0.00112 \\
(0.00310)\end{array}$ & $\begin{array}{l}-0.000531 \\
(0.000875)\end{array}$ & $\begin{array}{l}0.00508 \\
(0.0242)\end{array}$ & $\begin{array}{l}-0.0145 \\
(0.0195)\end{array}$ \\
\hline Inflation & $\begin{array}{c}0.0319 \\
(0.0368)\end{array}$ & $\begin{array}{l}-0.0145^{\star} \\
(0.00840)\end{array}$ & $\begin{array}{l}-0.502^{*} \\
(0.282)\end{array}$ & $\begin{array}{l}-0.0196 \\
(0.156)\end{array}$ \\
\hline Change in Openness & $\begin{array}{c}5.10 \mathrm{e}-09^{\star * *} \\
(1.12 \mathrm{e}-09)\end{array}$ & & & \\
\hline Change in Exchange Rate & $\begin{array}{l}1.093^{* * *} \\
(0.0275)\end{array}$ & & $\begin{array}{l}-0.157 \\
(0.168)\end{array}$ & $\begin{array}{l}-0.0533 \\
(0.0789)\end{array}$ \\
\hline GDP Per Capita & & $\begin{array}{l}0.0512^{* *} \\
(0.0201)\end{array}$ & & \\
\hline GDP Per Capita Squared & & $\begin{array}{c}-0.00276^{* *} \\
(0.00114)\end{array}$ & & \\
\hline Agricultural Share of VA & & $\begin{array}{c}0.0112 \\
(0.0290)\end{array}$ & & \\
\hline Openness & & & $\begin{array}{l}-1.55 e-09 \\
(1.14 e-08)\end{array}$ & $\begin{array}{c}2.88 \mathrm{e}-09 \\
(5.35 \mathrm{e}-09)\end{array}$ \\
\hline Population Growth & & & $\begin{array}{c}0.193 \\
(4.158)\end{array}$ & $\begin{array}{c}-7.835^{\star \star} \\
(3.304)\end{array}$ \\
\hline $\begin{array}{l}\text { Real GDP Per Capita } \\
\text { Growth }_{\mathrm{t}-1}\end{array}$ & $\begin{array}{c}0.0192 \\
(0.0188)\end{array}$ & & & \\
\hline Revenue/GDP $\mathrm{t}_{\mathrm{t}-1}$ & & $\begin{array}{l}0.796^{* * *} \\
(0.0372)\end{array}$ & & \\
\hline Portfolio Investment/GDP & & & $\begin{array}{l}0.221^{* *} \\
(0.104)\end{array}$ & \\
\hline Direct Investment/GDP $\mathrm{t}_{\mathrm{t}-1}$ & & & & $\begin{array}{l}0.466^{* * *} \\
(0.0925)\end{array}$ \\
\hline Observations & 596 & 545 & 555 & 584 \\
\hline Adjusted R-squared & 0.937 & 0.984 & 0.351 & 0.818 \\
\hline Country \& Year FE? & Yes & Yes & Yes & Yes \\
\hline
\end{tabular}




\section{Table 2. Full Sample, without Lagged Dependent Variables}

\begin{tabular}{|c|c|c|c|c|}
\hline $\begin{array}{c}\text { Full Results without } \\
\text { Lagged Dependent } \\
\text { Variables }\end{array}$ & $\begin{array}{l}\text { (1) } \\
\text { Real GDP Per Capita } \\
\text { Growth }\end{array}$ & $\begin{array}{c}\text { (2) } \\
\text { Revenues/GDP }\end{array}$ & $\begin{array}{c}\text { (3) } \\
\text { Portfolio } \\
\text { Investment/GDP }\end{array}$ & $\begin{array}{c}\text { (4) } \\
\text { Direct } \\
\text { Investment/ GDP }\end{array}$ \\
\hline NIC Shock & $\begin{array}{l}-0.0187^{\star *} \\
(0.00759)\end{array}$ & $\begin{array}{l}0.00131 \\
(0.00492)\end{array}$ & $\begin{array}{l}0.0272 \\
(0.0783)\end{array}$ & $\begin{array}{l}-0.0379 \\
(0.0582)\end{array}$ \\
\hline NIC Shock ${ }_{t-1}$ & $\begin{array}{l}-0.0109 * \\
(0.00546)\end{array}$ & $\begin{array}{l}0.00586 \\
(0.00641)\end{array}$ & $\begin{array}{l}-0.0548 \\
(0.0692)\end{array}$ & $\begin{array}{l}-0.0379 \\
(0.0682)\end{array}$ \\
\hline Anti-NIC & $\begin{array}{l}-0.00129 \\
(0.00311)\end{array}$ & $\begin{array}{l}-0.00584^{* *} \\
(0.00256)\end{array}$ & $\begin{array}{l}0.00300 \\
(0.0249)\end{array}$ & $\begin{array}{l}-0.0334 \\
(0.0354)\end{array}$ \\
\hline Inflation & $\begin{array}{l}0.0163 \\
(0.0329)\end{array}$ & $\begin{array}{l}0.000161 \\
(0.0266)\end{array}$ & $\begin{array}{l}-0.567^{*} \\
(0.297)\end{array}$ & $\begin{array}{l}0.166 \\
(0.342)\end{array}$ \\
\hline Change in Openness & $\begin{array}{l}5.15 \mathrm{e}-09^{\star \star \star} \\
(1.15 \mathrm{e}-09)\end{array}$ & & & \\
\hline Change in Exchange Rate & $\begin{array}{l}1.089^{\star \star \star} \\
(0.0259)\end{array}$ & & $\begin{array}{l}-0.198 \\
(0.193)\end{array}$ & $\begin{array}{l}0.0449 \\
(0.152)\end{array}$ \\
\hline GDP Per Capita & & $\begin{array}{l}0.296 * \star \star \\
(0.0714)\end{array}$ & & \\
\hline GDP Per Capita Squared & & $\begin{array}{l}-0.0162^{\star * \star} \\
(0.00344)\end{array}$ & & \\
\hline Agricultural Share of VA & & $\begin{array}{l}0.0849 \\
(0.131)\end{array}$ & & \\
\hline Openness & & & $\begin{array}{l}1.29 e-09 \\
(1.08 e-08)\end{array}$ & $\begin{array}{l}8.93 e-09 \\
(1.26 e-08)\end{array}$ \\
\hline Population Growth & & & $\begin{array}{l}0.977 \\
(5.300)\end{array}$ & $\begin{array}{l}-6.424^{*} \\
(3.737)\end{array}$ \\
\hline Observations & 596 & 550 & 559 & 587 \\
\hline Adjusted R-squared & 0.936 & 0.952 & 0.310 & 0.751 \\
\hline Country \& Year FE? & Yes & Yes & Yes & Yes \\
\hline
\end{tabular}


Table 3. Full Sample, Additional Robustness Checks

\begin{tabular}{|c|c|c|c|c|}
\hline $\begin{array}{c}\text { Dependent Variable: Real GDP } \\
\text { Per Capita Growth }\end{array}$ & $\begin{array}{c}(1) \\
\text { Level }\end{array}$ & $\begin{array}{c}\text { (2) } \\
\text { Level }\end{array}$ & $\begin{array}{c}\text { (3) } \\
\text { Rule of Law }\end{array}$ & $\begin{array}{c}(4) \\
\text { Government } \\
\text { Effectiveness }\end{array}$ \\
\hline NIC Shock & $\begin{array}{l}-0.0167^{*} \\
(0.00867)\end{array}$ & $\begin{array}{l}-.0182^{* *} \\
(0.00723)\end{array}$ & $\begin{array}{l}-.01790^{* *} \\
(0.00769)\end{array}$ & $\begin{array}{l}-.01796^{\star *} \\
(0.00769)\end{array}$ \\
\hline NIC Shock $k_{t-1}$ & $\begin{array}{l}-0.0106^{*} \\
(0.00541)\end{array}$ & $\begin{array}{l}-.012227^{*} \\
(0.006660)\end{array}$ & $\begin{array}{l}-.00934^{*} \\
(0.00550)\end{array}$ & $\begin{array}{c}-.0090 \\
(0.00560)\end{array}$ \\
\hline NIC Level Effect & $\begin{array}{c}-.0020 \\
(.00437)\end{array}$ & & & \\
\hline Control of Corruption Level Effect & & $\begin{array}{c}.0002529 \\
(.0004749)\end{array}$ & & \\
\hline Change in Rule of Law & & & $\begin{array}{l}-.000113 \\
(.005944)\end{array}$ & \\
\hline $\begin{array}{l}\text { Change in Government } \\
\text { Effectiveness }\end{array}$ & & & & $\begin{array}{l}.0093341 \\
(.009377)\end{array}$ \\
\hline Observations & 596 & 507 & 576 & 576 \\
\hline $\begin{array}{l}\text { Adjusted R-squared } \\
\text { Baseline Controls, LDV, and }\end{array}$ & 0.937 & 0.934 & 0.936 & 0.937 \\
\hline Constant? & Yes & Yes & Yes & Yes \\
\hline Country \& Year FE? & Yes & Yes & Yes & Yes \\
\hline \multicolumn{5}{|c|}{$\begin{array}{l}\text { Standard errors clustered by country in parentheses; constant included; * } \mathrm{p}<.10, * * \mathrm{p}<.05 \text {, and } * * * \mathrm{p}<.01 \text {. Rule of law (law and order) and } \\
\text { government effectiveness (bureaucratic quality) are sourced from ICRG's database and are scores ranging from } 0-6 \text { and } 0-4 \text {, respectively, with } \\
\text { higher values representing better scores. For more information, see https://www.prsgroup.com/wp- } \\
\text { content/uploads/2012/11/icrgmethodology.pdf. }\end{array}$} \\
\hline
\end{tabular}

Table 4. Sub-sample, Without Lagged Dependent Variables

\begin{tabular}{|lcccc|}
\hline \multicolumn{4}{|c|}{ Table 4. Sub-sample, Without Lagged Dependent Variables } \\
\hline $\begin{array}{c}\text { Dependent Variable: Real GDP Per } \\
\text { Capita Growth without Lagged } \\
\text { Dependent Variables }\end{array}$ & $(1)$ & $(2)$ & $\begin{array}{c}(3) \\
\text { High NIC } \\
\left(>75^{\text {th }}\right. \\
\text { Percentile })\end{array}$ & $\begin{array}{c}\text { Low NIC } \\
\left(<25^{\text {th }}\right. \\
\text { Percentile })\end{array}$ \\
\hline NIC Shock & Advanced & EMDCs & -0.0181 & -0.00423 \\
& -0.00756 & $-0.0230^{*}$ & $(0.0179)$ & $(0.00527)$ \\
NIC Shockt-1 & $(0.00768)$ & $(0.0126)$ & & -0.00372 \\
& -0.00887 & -0.0116 & $-0.0192^{* *}$ & $(0.0103)$ \\
\hline Observations & $(0.00691)$ & $(0.00842)$ & $(0.00740)$ & 140 \\
Adjusted R-squared & 220 & 376 & 140 & 0.924 \\
Country and Year FE? & 0.889 & 0.944 & 0.967 & Yes \\
Full Set of Controls? & Yes & Yes & Yes & Yes \\
\hline Standard errors clustered by country in parentheses; constant included; ${ }^{*} p<.10,{ }^{* *} p<.05$, and ${ }^{* * *} p<.01$. & \\
\hline
\end{tabular}


60

\begin{tabular}{|c|c|c|c|c|c|}
\hline & (1) & (2) & (3) & (4) & (5) \\
\hline Dependent Variable: Real GDP Per Capita Growth & FAD FTES & MCM FTES & STA FTES & LEG FTES & All FTEs \\
\hline FTEs, by Type $t-1$ & $\begin{array}{c}0.00259 \\
(0.00438)\end{array}$ & $\begin{array}{c}0.00639 \\
(0.0105)\end{array}$ & $\begin{array}{c}0.0777 \\
(0.0550)\end{array}$ & $\begin{array}{c}0.00579 * \\
(0.00303)\end{array}$ & $\begin{array}{l}0.00817^{* *} \\
(0.00366)\end{array}$ \\
\hline FTEs, by Type $t_{-2}$ & $\begin{array}{l}0.00334 \\
(0.00473)\end{array}$ & $\begin{array}{c}0.0186 \\
(0.0148)\end{array}$ & $\begin{array}{c}0.0351 \\
(0.0243)\end{array}$ & $\begin{array}{l}-0.00564^{*} \\
(0.00312)\end{array}$ & $\begin{array}{l}-0.00408 \\
(0.00398)\end{array}$ \\
\hline Observations & 229 & 229 & 229 & 229 & 229 \\
\hline Adjusted R-squared & 0.898 & 0.900 & 0.907 & 0.898 & 0.899 \\
\hline Country and Year FE? & Yes & Yes & Yes & Yes & Yes \\
\hline Full Set of Controls \& Lagged Dependent Variables? & Yes & Yes & Yes & Yes & Yes \\
\hline
\end{tabular}




\section{Appendix VI. Data Description and Sources}

\begin{tabular}{|c|c|c|}
\hline Variable & Definition & Source \\
\hline Real GDP & Gross domestic product, constant prices, USD & IMF \\
\hline Nominal GDP & Gross domestic product, current prices, USD & IMF \\
\hline Real GDP per capita & Gross domestic product, constant prices, per capita & IMF \\
\hline PPP GDP & Nominal GDP in PPP\$ & IMF \\
\hline $\begin{array}{l}\text { Consumer Price } \\
\text { Index }\end{array}$ & Consumer Prices, period average & IMF \\
\hline Inflation & Consumer Prices, period average, percent change & IMF \\
\hline Exports & Exports of goods and services, constant prices & IMF \\
\hline Imports & Imports of goods and services, constant prices & IMF \\
\hline Terms of Trade & Terms of trade, total, US Dollars, percent change & IMF \\
\hline Revenue/GDP & General government revenue, percent of fiscal year GDP & IMF \\
\hline Tax Revenue/GDP & General government taxes, percent of fiscal year GDP & IMF \\
\hline Expenditure/GDP & $\begin{array}{l}\text { General government total expenditure, percent of Fiscal year } \\
\text { GDP }\end{array}$ & IMF \\
\hline Fiscal Balance/GDP & $\begin{array}{l}\text { General government net lending/borrowing, percent of fiscal } \\
\text { year GDP }\end{array}$ & IMF \\
\hline Debt/GDP & General government gross debt, percent of Fiscal year GDP & IMF \\
\hline Investment & Gross fixed capital formation, constant prices & IMF \\
\hline Unemployment & Unemployment rate & IMF \\
\hline Broad Money & Broad money & IMF \\
\hline NEER & $\begin{array}{l}\text { Nominal Effective Exchange Rate, Trade Partners by } \\
\text { Consumer Price Index, Index }\end{array}$ & IMF \\
\hline $\begin{array}{l}\text { Bilateral Exchange } \\
\text { Rate }\end{array}$ & US Dollar per National Currency, Period Average, Rate & IMF \\
\hline Oil Price & Brent & IMF \\
\hline Direct Investment & $\begin{array}{l}\text { Financial Account, Direct Investment, Net Incurrence of } \\
\text { Liabilities, US Dollars }\end{array}$ & IMF \\
\hline Portfolio Investment & $\begin{array}{l}\text { Financial Account, Portfolio Investment, Net Incurrence of } \\
\text { Liabilities, US Dollars }\end{array}$ & IMF \\
\hline $\begin{array}{l}\text { Nominal Interest } \\
\text { Rate }\end{array}$ & Financial, Interest Rates, Lending Rate, Percent per annum & IMF \\
\hline Real Interest Rate & Real interest rate & World Bank \\
\hline $\begin{array}{l}\text { Money Market } \\
\text { Rates }\end{array}$ & Money Market Rates & IMF, CEIC, OECD \\
\hline
\end{tabular}




\begin{tabular}{|c|c|c|}
\hline C-efficiency ratio & Proxy for tax-collection efficiency & IMF \\
\hline $\begin{array}{l}\text { Portfolio Equity } \\
\text { Assets }\end{array}$ & Portfolio Equity Assets (stock) & $\begin{array}{l}\text { External Wealth of } \\
\text { Nations Mark II }\end{array}$ \\
\hline $\begin{array}{l}\text { Portfolio Equity } \\
\text { Liabilities }\end{array}$ & Portfolio Equity Liabilities (stock) & $\begin{array}{l}\text { External Wealth of } \\
\text { Nations Mark II }\end{array}$ \\
\hline FDI Assets & FDI Assets (stock) & $\begin{array}{l}\text { External Wealth of } \\
\text { Nations Mark II }\end{array}$ \\
\hline FDI Liabilities & FDI Liabilities (stock) & $\begin{array}{l}\text { External Wealth of } \\
\text { Nations Mark II }\end{array}$ \\
\hline Debt Assets & Debt Assets (stock) & $\begin{array}{l}\text { External Wealth of } \\
\text { Nations Mark II }\end{array}$ \\
\hline Debt Liabilities & Debt Liabilities (stock) & $\begin{array}{l}\text { External Wealth of } \\
\text { Nations Mark II }\end{array}$ \\
\hline FX Reserves & FX Reserves (- gold) & $\begin{array}{l}\text { External Wealth of } \\
\text { Nations Mark II }\end{array}$ \\
\hline Credit/GDP & $\begin{array}{l}\text { Credit to non-financial sector from All sectors at Market value } \\
\text { - Percentage of GDP - Adjusted for breaks }\end{array}$ & BIS \\
\hline Private Credit/GDP & $\begin{array}{l}\text { Credit to Private non-financial sector from All sectors at } \\
\text { Market value - Percentage of GDP - Adjusted for breaks }\end{array}$ & BIS \\
\hline Population & Population, total & World Bank \\
\hline Population Growth & Population growth (annual \%) & World Bank \\
\hline Primary Education & Gross enrollment ratio, primary, both sexes (\%) & World Bank \\
\hline Tertiary Education & Gross enrolment ratio, tertiary, both sexes (\%) & World Bank \\
\hline International Aid & $\begin{array}{l}\text { Net official development assistance and official aid received } \\
\text { (constant } 2013 \text { US\$) }\end{array}$ & World Bank \\
\hline $\begin{array}{l}\text { Public Expenditure } \\
\text { on Education }\end{array}$ & $\begin{array}{l}\text { Expenditure on education as \% of total government } \\
\text { expenditure }(\%)\end{array}$ & World Bank \\
\hline $\begin{array}{l}\text { Agriculture Value } \\
\text { Added }\end{array}$ & Agriculture value added & World Bank \\
\hline Inequality & Gini Index (WB estimate) & World Bank \\
\hline $\begin{array}{l}\text { Institutional } \\
\text { Variable I }\end{array}$ & $\begin{array}{l}\text { Government Effectiveness Measure - higher score indicates } \\
\text { better bureaucratic quality }\end{array}$ & ICRG \\
\hline $\begin{array}{l}\text { Institutional } \\
\text { Variable II }\end{array}$ & $\begin{array}{l}\text { Rule of Law Measure - higher score indicates better law and } \\
\text { order }\end{array}$ & ICRG \\
\hline $\begin{array}{l}\text { Institutional } \\
\text { Variable III }\end{array}$ & $\begin{array}{l}\text { Corruption Measure - higher score indicates better control of } \\
\text { corruption }\end{array}$ & ICRG \\
\hline $\begin{array}{l}\text { Institutional } \\
\text { Variable IV }\end{array}$ & $\begin{array}{l}\text { Control of Corruption - higher rank indicates better control of } \\
\text { corruption }\end{array}$ & World Bank \\
\hline $\begin{array}{l}\text { Institutional } \\
\text { Variable V }\end{array}$ & $\begin{array}{l}\text { Corruption Perceptions Index - higher rank indicates lower } \\
\text { perception of corruption }\end{array}$ & $\begin{array}{l}\text { Transparency } \\
\text { International }\end{array}$ \\
\hline
\end{tabular}




\begin{tabular}{|lll|}
\hline $\begin{array}{l}\text { Institutional } \\
\text { Variable VI }\end{array}$ & $\begin{array}{l}\text { Human Development Index - higher rank indicates higher } \\
\text { human development }\end{array}$ & UNDP \\
Variable VII & $\begin{array}{l}\text { Proxy for regime (democracy to autocracy) - higher score } \\
\text { indicates a more democratic regime }\end{array}$ & $\begin{array}{l}\text { Polity IV: Center for } \\
\text { Systemic Peace }\end{array}$ \\
$\begin{array}{l}\text { Institutional } \\
\text { Variable VIII }\end{array}$ & $\begin{array}{l}\text { Proxy for ethnic/civil conflict - higher score indicates more } \\
\text { domestic conflict }\end{array}$ & $\begin{array}{l}\text { Major Episodes of } \\
\text { Political Violence: } \\
\text { Center for Systemic } \\
\text { Institutional }\end{array}$ \\
$\begin{array}{l}\text { Variable IX } \\
\text { Stock Market Price }\end{array}$ & $\begin{array}{l}\text { Proxy for language diversity - higher score indicates greater } \\
\text { language diversity }\end{array}$ & Ethnologue \\
$\begin{array}{l}\text { Sovereign Bond } \\
\text { spreads }-5 \mathrm{Y}\end{array}$ & Sovereign bond spreads vs US Treasuries - 5 yr & Bloomberg \\
$\begin{array}{l}\text { Sovereign Bond } \\
\text { spreads - 2Y }\end{array}$ & Sovereign bond spreads vs US Treasuries - 2yr & Bloomberg \\
\hline
\end{tabular}




\section{REFERENCES}

Acemoglu, D., S. Johnson, J. Robinson, and Y. Thaicharoen, 2003, "Institutional causes, macroeconomic symptoms: volatility, crises and growth." Journal of Monetary Economics, Vol. 50 pp. 49-123.

Akitoby, B., and Stratmann, T., 2010, "The Value of Institutions for Financial Markets: Evidence from Emerging Markets," Review of World Economics, Vol. 146 (4), 78197.

Allita, A. B., and Zaiane, S., 2017, "The Impact of News Events on the Tunisian Stock Market Volatility: A Post-Revolutionary Study," Corporate Ownership and Control, Vol. 14 (2), pp. 230-237

Alonso-Terme, R., Davoodi, H., and Gupta, S., 2002, "Does corruption affect income inequality and poverty?" Economics of Governance, Vol. 3 (1), pp. 23-45.

Amano, S., Giannakopoulos, A., and Maras, K., 2009, "Party Financing in Germany and Japan: Comparative Perspectives on Political Corruption," Electronic Journal of Contemporary Japanese Studies, Article IV, October.

Andersen, T. B., 2009, "E-Government as an Anti-corruption Strategy," Information Economics and Policy, Vol. 21 (3), pp. 201-210.

Anderson, J. H., and Gray, C. W., 2007, "Policies and Corruption Outcomes," in Anticorruption in Transition 3. Who is Succeeding... and Why?, No. 37089, pp. 43-77 (Washington, DC: The World Bank).

Araki, S., and Claus, I., 2014, “A Comparative Analysis of Tax Administration in Asia and the Pacific" (New York: Cornell University ILR School).

Arbatli, E. C., Davis, S. J., Ito, A., Miake, N., and Saito, I., 2017, "Policy Uncertainty in Japan,” NBER Working Paper No. 23411, May (Massachusetts: National Bureau of Economic Research).

Asian Development Bank, 2016, Annual Report (Manila).

Aucoin, P., and Heintzman, R., 2000, “The Dialectics of Accountability for Performance in Public Management Reform."

Baker, S. R., Bloom, N., and Davis, S. J., 2016, "Measuring Economic Policy Uncertainty," The Quarterly Journal of Economics, Vol. 131 (4), pp. 1593-1636.

Berlinger, J., 2012, "Why China Should Study Singapore's Anti-Corruption Strategy," Business Insider (December). Available at http://www.businessinsider.com/whycKoha-should-study-singapores-anti-corruption-strategy-2012-12. 
Bertot, J. C., Grimes, J. M., and Jaeger, P. T., 2010, "Using ICTs to create a culture of transparency: E-government and social media as openness and anti-corruption tools for societies," Government Information Quarterly, Vol. 98 (July), pp. 264-271.

Bold, T., Kimenyi, M., Mwabu, G., and Sandefur, J., 2011, "Why Did Abolishing Fees Not Increase Public School Enrollment in Kenya?,” Working Paper No. 271 (Washington, DC: Center for Global Development).

Bolongaita, E. P., 2010, “An Exception to the Rule? Why Indonesia’s Anti-Corruption Commission succeeds when others don't - a comparison with the Philippines' Ombudsman," U4 Anti-Corruption Resource Centre, U4 Issue No. 4, August (Chr. Michelsen Institute (CMI), Anti-Corruption Resource Center).

Brogaard, J., and Detzel, A., 2015, “The Asset-Pricing Implications of Government Economic Policy Uncertainty," Management Science, Vol. 61 (1), pp. 3-18.

Bunduchi, R., Franco, M., Pagliari, C., and Tursunbayeva, A., 2015,'Human Resource Information Systems in Health Care: Protocol for a Systematic Review," JMIR Research Protocol, Vol. 4 (4).

Cameron, L., Chaudhuri, A., Erkal, N., and Gangadharan, L., 2009, "Propensities to Engage In and Punish Corrupt Behavior: Experimental Evidence from Australia, India, Indonesia and Singapore," Journal of Public Economics 93 (7-9), pp. 843-851.

Campos, J. E., Lien, D., and Pradhan, S., 1999, “The Impact of Corruption on Investment: Predictability matters," World development, Vol. 27, No. 6, pp. 1059-1067.

Campos, N., Dimova, R., and Saleh, A., 2010, "Whither Corruption? A Quantitative Survey of the Literature on Corruption and Growth," Discussion Paper No. 5334 (Bonn: Institute for the Study of Labor).

Cavoli, T., and Wilson, J., 2015, Corruption, Central Bank (in)dependence and Optimal Monetary Policy in a Simple Model, Journal of Policy Modeling, 37 (3): 501-9.

Chêne, M., 2016, "Literature review: The use of ICTs in the fight against corruption," No. 6, November (U4 Anti-Corruption Resource Center).

Chene, M., 2008, “Overview of Corruption in Pakistan,” U4 Anti-Corruption Resource, Centre. Available at: http://www.u4.no/helpdesk/helpdesk/query.cfm?id=174.

Ciocchini, F., Durbin, E., and Ng, D. T., 2003, "Does corruption increase emerging market bond spreads?" Journal of Economics and Business, 55 (5-6), 503-528.

Costas-Pérez, E., Solé-Ollé, A., and Sorribas-Navarro, P., 2012, "Corruption scandals, voter information, and accountability," European Journal of Political Economy, 28 (4), pp. 469-484.

CPIB, 2016, “Our Heritage.” Available at: https://www.cpib.gov.sg/about-cpib/our-heritage. 
Dadasov, D., Dykes, V., Khaghaghordyan, A., Kossow, N., Kukutschka N. A., Martínez, R. B., and Mungiu-Pippidi, A., 2017, "Index of Public Integrity," European Research Centre for Anti-Corruption and State-Building (ERCAS). Available at: http://www.integrity-index.org.

Davies, T., and Fumega, S., 2014, "Mixed incentives: Adopting ICT innovations for transparency, accountability, and anti-corruption," No. 4, June (Chr. Michelsen Institute (CMI), Anti-Corruption Resource Center).

Detragiache, E., Gupta, P., and Tressel,T., 2005, Finance in Lower-Income Countries: An Empirical Exploration, IMF Working Paper 05/167, International Monetary Fund, Washington.

Duflo, E., Hanna, R., and Ryan, S. P., 2012, "Incentives work: Getting Teachers to Come to School," American Economic Review, 102 (4), pp.1241-1278.

Dupuy, E.P., and Serrat, O., 2014, "Fighting Corruption with ICT: Strengthening Civil Society’s Role,’June, pp. 797-811 (Manila: Asian Development Bank).

Engelschalk, M., Ferreira, C., and Mayville, W., 2007, “The Challenge of Combating Corruption in Customs Administrations," in Campos, J., and Sanjay, P., (eds), The Many Faces of Corruption: Tracking Vulnerabilities at the Sector Level, pp. 367-86 (Washington, DC: The World Bank).

Erhieyovwe, E. K., and Onokero, I. I., 2013, "Corruption, Foreign Direct Investment and its Impact on Exchange Rate of the Nigerian Economy" Mediterranean Journal of Social Sciences, 4 (3), p. 345.

Fakhfekh, M., Jarboui, A., and Jeribi, A., 2015, “Tunisian revolution and stock market volatility: evidence from FIEGARCH model," Managerial Finance, Vol. 41 (10), pp. 1112-1135.

Fama, E. F., 1970, "Efficient Capital Markets: A Review of Theory and Empirical Work," The journal of Finance, Vol. 25 (2), pp. 383-417.

Gigler, B. S., 2015, Development as Freedom in a Digital Age: Experiences from the Rural Poor in Bolivia (Washington, DC: The World Bank).

Goel, R. K., Naretta, M. A., and Nelson, M. A., 2012, “The internet as an indicator of corruption awareness," European Journal of Political Economy, 28 (1), 64-75.

Grigorian, D., and Manole, V., 2017, "Sovereign risk and deposit dynamics: evidence from Europe," Applied Economics, Vol. 49 (29), pp. 2851-2860.

Guiso, L., Sapienza, P., and Zingales, L., 2009, "Cultural biases in Economic Exchange?," The Quarterly Journal of Economics, Vol. 124 (3), pp. 1095-1131. 
Gunnemann, J., 2014, “The Impact of Economic Policy Uncertainty: New Evidence from Europe," unpublished manuscript.

Gupta, S., Keen, M., Shah, A., and Verdier, G., 2017, Digital Revolutions in Public Finance (Washington, DC: International Monetary Fund).

Heckelman, J. C., \& Powell, B., 2010. "Corruption and the institutional environment for growth," Comparative Economic Studies, Vol. 52(3), pp. 351-378.

Hershman, M. J., 2016, “Anti-Corruption Program in Malaysia - A Comprehensive Approach," The World Post. Available at: https://www.huffingtonpost.com/michaelj-hershman/malaysia-anti corruption b 1619111.html.

Hlatshwayo, S., and Saxegaard, M., 2016, “The Consequences of Policy Uncertainty: Disconnects and Dilutions in the South African Real Effective Exchange Rate-Export Relationship," IMF Working Paper No. 113, pp. 1-30. (Washington, DC: International Monetary Fund).

Huang, H., and Shang-Jin, W., 2006, Monetary Policies for Developing Countries: The Role of Institutional Quality, Journal of International Economics, 70 (1): 239-52.

Huntington, S.P., 1968, "Political order in changing societies." New Haven: Yale University Press.

Inge, A., and Fjeldstad, O. H., 2000, "Corruption. A selected and annotated bibliography," P. 140 (Bergen: Chr. Michelsen Institute (commissioned by Norad)).

International Monetary Fund, 2003. "Growth and Institutions." World Economic Outlook, April, Chapter III, Washington, DC.

Jordà, Ò., 2005, "Estimation and inference of impulse responses by local projections," American Economic Review, Vol. 95 (1), pp. 161-182.

Keen, M., and Baunsgaard, T., 2005, “Tax Revenue and (or?) Trade Liberalization," IMF Working Paper No. 5-112 (Washington, DC: International Monetary Fund).

Khan, F., 2016, "Combating Corruption in Pakistan," Asian Education and Development Studies, Vol. 5 (2), pp.195-210.

Kis-Katos, K., and Schulze, G. G., 2013, "Corruption in Southeast Asia: a survey of recent research," Asian-Pacific Economic Literature.

Klitgaard, R., 1988, Controlling Corruption (Berkeley and Los Angeles: University of California Press).

,2015a, Addressing Corruption Together (Paris: OECD, Development Cooperation Directorate). 
, 2015b, Addressing Corruption Together, background paper prepared for the OECD Symposium on Anti-Corruption Development Assistance: Good Practices among Providers of Development Co-operation, which took place in Paris on December 11-12, 2014 (Paris: Organisation for Economic Co-operation and Development).

Koh, T. H., 2011, "Corruption Control in Singapore," United Nations Asia and Far East Institute for the Prevention of Crime and the Treatment of Offenders (UNAFEI), Resource Material Series No. 83, pp. 122-131.

Kozlowski, J., Veldkamp, L., and Venkateswaran, V., 2016, "The Tail that Wags the Economy: Belief-Driven Business Cycles and Persistent Stagnation," CEPR Discussion Papers, No. 11352 (London: Centre for Economic Policy Research)

Krueger, A. O., 1974, "The political economy of the rent-seeking society," The American economic review, Vol. 64 (3), pp. 291-303.

Kuris, G., 2012a, Inviting a Tiger into Your Home: Indonesia Creates an Anti-Corruption Commission with Teeth, 2002-2007 (Princeton University: Innovations for Successful Societies). , 2012b, Holding the High Ground with Public Support: Indonesia's AntiCorruption Commission Digs In, 2007-2011 (Princeton University: Innovations for Successful Societies).

Lee, C. M., and Ng, D., 2009, "Corruption and International Valuation: Does Virtue Pay?," The Journal of Investing, Vol. 18 (4), pp. 23-41.

Lee, H. L., 2016, "Fight against corruption: Singapore's experience" in Essay for the AntiCorruption Summit, London, May. Available at: http://www.straitstimes.com/opinion/fight-against-corruption-singapores-experience.

Lee, S., and Oh, K., 2007, "Corruption in Asia: Pervasiveness and Arbitrariness." Asia Pacific Journal of Management, Vol. 24, pp. 97-114.

Leff, N.H., 1964, "Economic development through bureaucratic corruption." American Behavioral Scientist Vol 8, pp.8-14. Reprint in Heidenheimer, A.J., M. Johnston and V.T. LeVine (eds), 1989, "Political corruption: A Handbook," pp. 389-403. Oxford: Transaction Books.

Linzer, D. A., and Staton, J. K., 2015, “A global measure of judicial independence, 19482012," Journal of Law and Courts, Vol. 3 (2), pp. 223-256.

Lu, J., Shi, T., and Zhu, J., 2013, "When Grapevine News Meets Mass Media: Different Information Sources and Popular Perceptions of Government Corruption in Mainland China," Comparative Political Studies, Vol. 46 (8), pp. 920-946. 
Marquette, H., and Peiffer, C., 1996, "The Effects of Corruption on Growth, Investment, and Government Expenditure,” IMF Working Paper No. 96/98, pp. 1-28. (Washington, DC: International Monetary Fund). , 2015, “Corruption and Collective Action,” Research Paper No. 32, January (Developmental Leadership Program and U4 Anti-Corruption Resource Centre).

Mauro, P., 1995, "Corruption and Growth.” The Quarterly Journal of Economics, Vol. 110 (3), pp. 681-712.

Maxwell, A., 2017, "Indonesia's Corruption Eradication Commission Law Weathers the Storm, For Now," The Diplomat (September). Available via the Internet: https://thediplomat.com/2017/09/indonesias-corruption-eradication-commission-lawweathers-the-storm-for-now/.

Meagher, P., 2005, “Anti-corruption agencies: Rhetoric Versus reality," The Journal of Policy Reform, Vol. 8 (1), pp. 69-103.

Méon, P., and K. Sekkat, 2005, "Does corruption grease or sand the wheels of growth?" Public Choice Vol. 122, pp. 69-97.

Michael, B., and Polner, M., 2008, "Fighting Corruption on the Transdnistrian Border: Lessons from Failed and Successful Anti-Corruption Programmes," Paper presented at the University of Paris, May 10, 2007.

MOJ, Estonia, 2006-2014, Report. Available via the Internet: http://www.korruptsioon.ee/et/korruptsioon-eestis/statistika.

Murphy, K., Shleifer, A., and Vishney, R., 1991, "The Allocation of Talent: Implication for Growth” The Quarterly Journal of Economics, Vol. 106 (2), pp. 503-30.

Persson, A., Rothstein, B., and Teorell, J., 2010, “The failure of Anti-Corruption Policies-A Theoretical Mischaracterization of the Problem," QoG Working Paper Series 2010:19 (Gothenburg: The Quality of Government Institute, University of Gothenburg).

Phongpaichit, P., and Baker, C. J., 2004, Thaksin: The business of politics in Thailand (Chiang Mai: Silkworm Books).

Pina, V., Royo, S., and Torres, L., 2007, “Are ICTs Improving Transparency and Accountability in the EU Regional and Local Governments? An Empirical Study," Public Administration, Vol. 85, No. 2, pp. 449-72.

Pope, J., 2000, Confronting Corruption: the elements of a national integrity system (Transparency International).

Quah, J. S.T., 1988, "Corruption in Asia with Special Reference to Singapore: Patterns and Consequences," Asian Journal of Public Administration, Vol. 10, (1), pp. 80-98. 
Rajkumar, A., S., and Vinaya, S., 2002, "Public Spending and Outcomes: Does Governance Matter?," Policy Research Working Paper No.2840 (Washington, DC: The World Bank).

Razinabc, A., Sadkaa, E., and Yuend, C. W., 1998, “A pecking order of capital inflows and international tax principles," Journal of International Economics, Vol. 44 (1), pp. 45 68.

Redl, C., 2015, "Macroeconomic Uncertainty in South Africa,” ERSA Working Paper No. 509, March (Cape Town: Economic Research South Africa).

Reinikka, R., and Svensson, J., 2004, "Local Capture: Evidence from a Central Government Transfer Program in Uganda," Quarterly Journal of Economics, 119 (2), pp. 679-705.

Rizzica, L., and Tonello, M., 2018, "Persuadable Perceptions. The Effect of Media Content on Beliefs About Corruption," Working Paper, (Rome: Bank of Italy, Statistics and Research, Structural Economic Analysis Directorate, Law and Economics Division.).

Sapienza, P., and Zingales, L., 2012, “A Trust Crisis,” International Review of Finance, Vol. 12 (2), pp. 123-131.

Shapiro, A. H., Sudhof, M., and Wilson, D., 2018, "Measuring News Sentiment," Working Paper No. 2017-01, March (San Francisco: Federal Reserve Bank of San Francisco).

Shim, D. and T. Eom, 2008, "E-Government and Anti-Corruption: Empirical Analysis of International Data. International Journal of Public Administration, Vol. 13, pp. 298316.

Siddiquee, N. A., 2009, "Combating Corruption and Managing Integrity in Malaysia: A Critical Overview of Recent Strategies and Initiatives," Public Organization Review, Vol. 10 (2), pp. 153-171.

Srivastava, B., 2016, Tackling Corruption With Agents \& ICT: A Vision (IBM Research).

Transparency International (TI) Malaysia, 2014, "Give MACC Prosecution Power." Available at: http://transparency.org.my/media-and-publications/give-maccprosecution-power/.

Transparency International (TI), 2013, "Best Practices for Anti-Corruption Commissions," TI Anti-Corruption Helpdesk - Providing On-Demand Research to Help Fight Corruption.

UNDP, 2015, A Users' Guide to Measuring Corruption (Norway: United Nations Development Programme, Oslo Governance Centre).

UNIFEM, 2008, Analysis of Transparency International Global Corruption Barometer database. 
USAID, 2016, Report on Combatting Corruption and Strengthening Integrity in Jamaica.

Wei, S. J., 1997, "Why is Corruption So Much More Taxing Than Tax? Arbitrariness Kills," NBER Working Paper No. 62 (Cambridge, MA: National Bureau of Economic Research).

Wei, S. J., and Wu, Y., 2002, "Negative alchemy? Corruption, Composition of Capital Flows, and Currency Crises," in Preventing Currency Crises in Emerging Markets, pp. 461-506 (Chicago: University of Chicago Press).

Wheeler, D., and Mody, A., 1992, "International investment location decisions: The case of U.S. firms,” Journal of International Economics, Vol. 33 (1-2), pp. 57-76.

Wickberg, S., 2012, Technological innovations to identify and reduce corruption (Transparency International).

Wolfers, J., and Zitzewitz, E., 2016, "What do financial markets think of the 2016 election," Working Paper. Available at: https://www.brookings.edu/wpcontent/uploads/2016/10/what-do-financial-markets-think-of-the-2016election_102016_wolferszitzewitz.pdf.

World Bank, 2016, Report on Corruption. 